Florida International University FIU Digital Commons

$10-13-2015$

\title{
Understanding the Impact of the Property Tax Appeal Process on Assessment Uniformity: Procedures, Structures, and Outcomes
}

Michael P. Paparesta

Florida International University, mpapa002@fiu.edu

DOI: $10.25148 /$ etd.FIDC000144

Follow this and additional works at: https://digitalcommons.fiu.edu/etd

Part of the Other Public Affairs, Public Policy and Public Administration Commons

\section{Recommended Citation}

Paparesta, Michael P., "Understanding the Impact of the Property Tax Appeal Process on Assessment Uniformity: Procedures, Structures, and Outcomes" (2015). FIU Electronic Theses and Dissertations. 2252.

https://digitalcommons.fiu.edu/etd/2252 


\section{FLORIDA INTERNATIONAL UNIVERSITY}

Miami, Florida

UNDERSTANDING THE IMPACT OF THE PROPERTY TAX APPEAL PROCESS

ON ASSESSMENT UNIFORMITY: PROCEDURES, STRUCTURES, AND

OUTCOMES

A dissertation submitted in partial fulfillment of the requirements for the degree of DOCTOR OF PHILOSOPHY

in

PUBLIC AFFAIRS

by

Michael P. Paparesta 
To: Dean John Stack

School of International and Public Affairs

This dissertation, written by Michael P. Paparesta, and entitled Understanding the Impact of the Property Tax Appeal Process on Assessment Uniformity: Procedures, Structures, and Outcomes, having been approved in respect to style and intellectual content, is referred to you for judgment.

We have read this dissertation and recommend that it be approved.

$\begin{array}{r}\hline \text { Shaoming Cheng } \\ \hline \text { Hai Guo } \\ \hline \text { Milena Neshkova } \\ \hline \text { John Zdanowicz }\end{array}$

Allan Rosenbaum, Major Professor

Date of Defense: October 13, 2015

The dissertation of Michael P. Paparesta is approved.

Dean John Stack

School of International and Public Affairs

Dean Lakshmi N. Reddi University Graduate School

Florida International University, 2015 


\section{DEDICATION}

For Kennedy Elise Paparesta, Daddy loves you. 


\section{ACKNOWLEDGMENTS}

I begin by expressing my gratitude to the Lincoln Land Institute of Land Policy for its considerable contributions to my professional development. Whether it was the generous financial assistance provided through the C. Lowell Harriss Dissertation Fellowship, or the vast repository of books, policy reports, and working papers, this dissertation could not have been produced without their assistance. I would also like to acknowledge the dedicated staff and gracious benefactors of the Children's Home Incorporated. Since 1892, the Children's Home has helped to heal countless families in the Tampa Bay area. Thanks all for instilling in me, the courage to try.

Next, I wish to thank the members of my committee: Dr. Shaoming Cheng, Dr. Hai (David) Guo, Dr. Milena Neshkova, Dr. John Zdanowicz, and committee chair, Dr. Allan Rosenbaum, for their support and most importantly their patience during this long arduous journey. I would also like to recognize Carlota Valdes, Program Coordinator for the Institute for Public Management and Community Service, her assistance during the data collection phase was extremely helpful.

Additionally, I wish to express gratitude to my colleagues at the Miami-Dade County Property Appraiser’s Office. In particular, I want to thank my Division Director, Manuel Pernas for his continued support and encouragement. No one better understood the complexities of balancing a career with the pursuit of academic milestones.

Finally, I wish to thank my family (particularly my wife and daughters, Colette, Camryn, and Kennedy) and close friends for their patience over the last eight years. Many vacations and other family-fun events were deferred, so that I could pursue this dream. Nancy and Rhiana Paparesta, I love you. 


\begin{abstract}
OF THE DISSERTATION
UNDERSTANDING THE IMPACT OF THE PROPERTY TAX APPEAL PROCESS

ON ASSESSMENT UNIFORMITY: PROCEDURES, STRUCTURES, AND
\end{abstract}

OUTCOMES

by

Michael P. Paparesta

Florida International University, 2015

Miami, Florida

Professor Allan Rosenbaum, Major Professor

Property taxes serve as a vital revenue source for local governments. The revenues derived from the property tax function as the primary funding source for a variety of critical local public service systems. Property tax appeal systems serve as quasi-administrative-judicial mechanisms intended to assure the public that property tax assessments are correct, fair, and equitable. Despite these important functions, there is a paucity of empirical research related to property tax appeal systems.

This study contributes to property tax literature by identifying who participates in the property tax appeal process and examining their motivations for participation. In addition, the study sought to determine whether patterns of use and success in appeal systems affected the distribution of the tax burden. Data were collected by means of a survey distributed to single-family property owners from two Florida counties. In addition, state and county documents were analyzed to determine appeal patterns and examine the impact on assessment uniformity, over a three-year period. 
The survey data provided contextual evidence that single-family property owners are not as troubled by property taxes as they are by the conduct of local government officials. The analyses of the decision to appeal indicated that more expensive properties and properties excluded from initial uniformity analyses were more likely to be appealed, while properties with homestead exemptions were less likely to be appealed.

The value change analyses indicated that appeals are clustered in certain geographical areas; however, these areas do not always experience a greater percentage of the value changes. Interestingly, professional representation did not increase the probability of obtaining a reduction in value. Other relationships between the variables were discovered, but often with weak predictive ability.

Findings from the assessment uniformity analyses were also interesting. The results indicated that the appeals mechanisms in both counties improved assessment uniformity. On average, appealed properties exhibited greater horizontal and vertical inequities, as compared to non-appealed properties, prior to the appeals process. After, the appeal process was completed; the indicators of horizontal and vertical equity were largely improved. However, there were some indications of regressivity in the final year of the study. 


\section{TABLE OF CONTENTS}

CHAPTER

PAGE

CHAPTER I: INTRODUCTION.............................................. 1

Introduction.................................................................... 1

Property Tax Administration Process.................................... 3

Identification of Problem............................................... 6

Research Questions, Hypotheses, and Methodology........................ 8

Theoretical Models...................................................... 10

Purpose of the Study .......................................................... 11

Significance of the Study .................................................. 12

Research Design.................................................... 13

Summary of Results................................................... 15

Scope and Limitations................................................ 16

Organization of the Dissertation.......................................... 17

CHAPTER II: EQUITY AND PROPERTY TAXATION......................... 18

Structure and Overview................................................... 18

Equity Principles.................................................... 18

Equity in Property Tax Administration...................................... 19

Traditional Indicators of Assessment Uniformity........................... 20

Uniformity in the State of Florida....................................... 25

CHAPTER III: ASSESSMENT REVIEW AND APPEAL SYSTEMS LITERATURE....... 30

Structure and Overview................................................... $\quad 30$

Assessment Review and Appeal Typology................................ 30

Empirical Examinations of Appeal and Review Systems......................... 32

The State of Florida's Appeal and Review System............................ 44

CHAPTER IV: RESEARCH DESIGN AND METHODOLOGY ................... 46

Structure and Overview...................................................... 46

Problem Statement.......................................................... 46

Hypotheses.............................................................. 46

Theoretical Models....................................................... 47

Research Design and Analyses......................................... 56

Custom-Designed Survey .............................................. 57

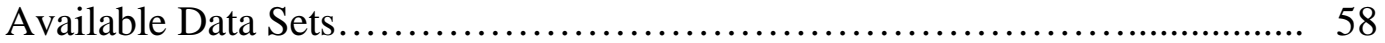

CHAPTER V: COUNTY SYNOPSES AND SURVEY RESULTS................ 61

Structure and Overview................................................. 61

Broward County Synopsis........................................... 61

Duval County Synopsis.................................................. 63

Survey Instrument....................................................... 65

Broward County Survey Results....................................... 67

Duval County Survey Results........................................ 75

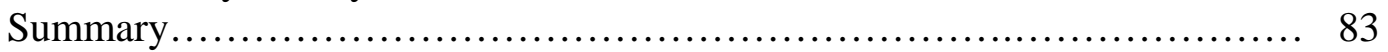


CHAPTER VI: BROWARD COUNTY APPEALS ANALYSES................. 85

Structure and Overview............................................... 85

Broward County Decision to Appeal Model................................. 85

Broward County Decision to Appeal Model Results....................... 91

Broward County Value Change Model......................................... 94

Broward County Value Change Model Results.............................. 100

Broward County Assessment Uniformity Results........................................... 102

Summary of Broward County Appeals Analyses............................ 108

CHAPTER VII: DUVAL COUNTY APPEALS ANALYSES ....................... 110

Structure and Overview................................................ 110

Duval County Decision to Appeal Model.................................. 110

Duval County Decision to Appeal Model Results............................ 116

Duval County Value Change Model............................................. 119

Duval County Value Change Model Results.................................. 125

Duval County Assessment Uniformity Results.............................................. 128

Summary of Duval County Appeals Analyses............................. 133

CHAPTER VIII: FINDINGS, DISCUSSION, AND CONCLUSION............... 136

Structure and Overview.............................................. 136

Survey Results....................................................... 138

Decision to Appeal..................................................... 140

Value Change.......................................................... 142

Assessment Uniformity............................................ 145

Conclusion............................................................ 147

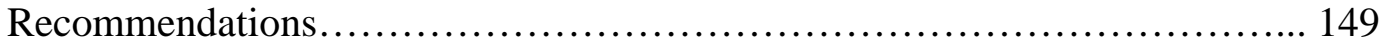

Opportunities for Further Study ..................................... 150

LIST OF REFERENCES................................................ 152

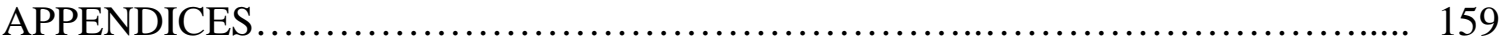

VITA .................................................................... 186 


\section{LIST OF TABLES}

TABLE

PAGE

1. Level of Assessment by State........................................ 22

2. Ratio Study Uniformity Standards.................................... 23

3. Decision to Appeal Model Explanatory Variables and Expected Signs............. 48

4. Market Value Change Model Explanatory Variables and Expected Signs....... 54

5. Broward County Survey Informal Appeal Request......................... 68

6. Broward County Survey Informal Appeal Request Result................... 68

7. Broward County Survey VAB Awareness............................... 69

8. Broward County Survey VAB Filing.................................. 69

9. Broward County Survey Use of Professional Representation................. 69

10. Broward County Survey VAB Reduction............................... 69

11. Broward County Survey VAB Motivation.............................. 70

12. Broward County Survey Efficient Use of Property Taxes................... 71

13. Broward County Survey Fairness of Property Taxes...................... 71

14. Broward County Survey Relationship of Property Taxes to Local Services....... 71

15. Broward County Survey Property Tax Compared to State Income Tax......... 72

16. Broward County Survey Property Tax Compared to Neighbors............... 72

17. Broward County Survey Greatest Household Budget Concern................. 73

18. Broward County Survey Opinion of County Government Efficiency........... 73

19. Broward County Survey Opinion of County Government Meeting Needs of Owners..... 74

20. Broward County Survey Opinion of County Officials Operating in Ethical Manner..... 74

21. Broward County Survey Opinion of Special Interest Influence............... 74

22. Broward County Survey Opinion of Service Level........................ 75 
23. Duval County Survey Informal Appeal Request............................. 76

24. Duval County Survey Informal Appeal Request Result....................... 76

25. Duval County Survey VAB Awareness..................................... 76

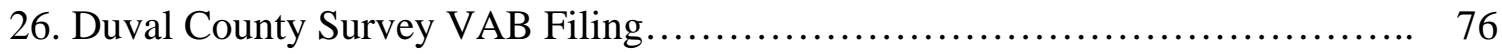

27. Duval County Survey Use of Professional Representation..................... 77

28. Duval County Survey VAB Reduction....................................... 77

29. Duval County Survey VAB Motivation................................... 77

30. Duval County Survey Efficient Use of Property Taxes........................ 78

31. Duval County Survey Fairness of Property Tax............................ 78

32. Duval County Survey Relationship of Property Taxes to Local Services.......... 79

33. Duval County Survey Property Tax Compared to State Income Tax............. 79

34. Duval County Survey Property Tax Compared to Neighbors................... 80

35. Duval County Survey Greatest Household Budget Concern.................... 80

36. Duval County Survey Opinion of County Government Efficiency.............. 81

37. Duval County Survey Opinion of County Government Meeting Needs of Owners........ 81

38. Duval County Survey Opinion of County Officials Operating in Ethical Manner 82

39. Duval County Survey Opinion of Special Interest Influence................... 82

40. Duval County Survey Opinion of Service Level........................... 82

41. Broward County VAB Petitions for a Reduction in Value 2010-2012............ 85

42. Descriptive Statistics for the Broward County Decision to Appeal Model......... 87

43. Firth Logit Results for Broward County Decision to Appeal Model.............. 93

44. Broward County Property Owners Utilizing a Professional Representative 2010-2012... 94

45. Descriptive Statistics for Broward County Value Change Model.................. 96

46. Broward County MLE Regression Results for Percentage Change in Market Value....... 101 
47. Broward County VAB Ratio Study Outlier Trimming 2010-2012............. 103

48. Broward County 2010 VAB Ratio Study Statistics........................ 106

49. Broward County 2011 VAB Ratio Study Statistics.................................. 107

50. Broward County 2012 VAB Ratio Study Statistics................................ 107

51. Duval County VAB Petitions for a Reduction in Value $2010-2012 . . . \ldots \ldots \ldots \ldots . . .110$

52. Descriptive Statistics for Duval County Decision to Appeal Model.............. 112

53. Firth Logit Results for Duval County Decision to Appeal Model........................ 118

54. Duval County Property Owner Use of Professional Representation 2010-2012... 120

55. Descriptive Statistics for Duval County Value Change Model........................... 121

56. Duval County MLE Regression Results for Percentage Change in Market Value........ 127

57. Duval County VAB Ratio Study Outlier Trimming 2010-2012......................... 129

58. Duval County 2010 VAB Ratio Study Statistics............................................ 132

59. Duval County 2011 VAB Ratio Study Statistics............................................. 133

60. Duval County 2012 VAB Ratio Study Statistics............................................ 133

61. Summary of Decision to Appeal Findings............................... 136

62. Summary of Value Change Findings................................... 137

63. Summary of Broward County Uniformity Indicators....................... 137

64. Summary of Duval County Uniformity Indicators......................... 138 


\section{LIST OF FIGURES}

FIGURE

PAGE

1. Average Property Tax in Dollars: Five Year Average 2007 - 2011................. 2

2. Property Tax Administration Process............................................ 5

3. Pops Assessment Review and Appeal System Typology ......................... 32

4. Broward County 2010 Percent of Single Family Parcels Appealed by Census Tract... 88

5. Broward County 2011 Percent of Single Family Parcels Appealed by Census Tract... 89

6. Broward County 2012 Percent of Single Family Parcels Appealed by Census Tract... 90

7. Broward County 2010 Percent of Successful Single Family Appeals by Census Tract 97

8. Broward County 2011 Percent of Successful Single Family Appeals by Census Tract 98

9. Broward County 2012 Percent of Successful Single Family Appeals by Census Tract 99

10. Duval County 2010 Percent of Single Family Parcels Appealed by Census Tract..... 113

11. Duval County 2011 Percent of Single Family Parcels Appealed by Census Tract..... 114

12. Duval County 2012 Percent of Single Family Parcels Appealed by Census Tract..... 115

13. Duval County 2010 Percent of Successful Single Family Appeals by Census Tract.... 122

14. Duval County 2011 Percent of Successful Single Family Appeals by Census Tract.... 123

15. Duval County 2012 Percent of Successful Single Family Appeals by Census Tract.... 124 


\section{LIST OF ABBREVIATIONS AND ACRONYMS}

ACIR Advisory Commission on Intergovernmental Affairs

AV

Assessed Value

COD Coefficient of Dispersion

CLUC County Land Use Code

FAC Florida Administrative Code

FDOR Florida Department of Revenue

FS Florida Statutes

IAAO International Association of Assessing Officers

LOA Level of Assessment

NAL Name-Address-Legal

PRD Price Related Differential

PTOP Property Tax Oversight Program

SDF Sales Data File

SP Sales Price

SLUC State Land Use Code

VAB Value Adjustment Board 


\section{CHAPTER I}

\section{INTRODUCTION}

The property tax has long served as a mechanism, by which, government entities have raised revenues to fund various projects and services. However, the property tax has never been a particularly popular revenue-generating mechanism for the citizens that bear its burden. Soon after the Norman Conquest of 1066, William the First ordered an assessment of everything in his kingdom, to which a tax was applied. This early incarnation of the property tax was ominously known as the Doomsday Survey (Groves, 1966). Centuries later, in an essay entitled, “The General Property Tax,” economist, Edwin R.A. Seligman famously lamented, "Practically, the general property tax as actually administered is beyond all doubt one of the worst taxes known in the civilized world “(Seligman, 1895, p. 62).

The notions of property rights, property taxation, and property tax fatigue cultivated in ancient Britannia were later transplanted to the new world. Since the colonial period, the property tax has maintained a position as a major revenue source for local governments in the United States. However, during this time, the property tax has faced strenuous political opposition and teetered on the brink of obscurity, only to be resurrected many times over. More recently, in response to taxpayers’ concerns, numerous property tax reforms have sprouted across the United States. From California’s Proposition 13 to Florida’s Save Our Homes Amendment, states have responded to taxpayer discontent by adopting tax policy measures such as assessment limits, revenue limits, and millage rate caps to assuage their citizens' apprehensions concerning the property tax (ACIR, 1995: Havemen \& Sexton, 2008). 
The motives for such acrimony towards the property tax stem from at least three factors: First, the tax is often paid in one lump sum (as opposed to the sales tax, in which payments occur in small increments). Second, in times of rapid real estate value appreciation, the tax is levied on an unrealized accumulation of wealth of a property owner and these accretions do not necessarily correspond to income received. Third, the tax base is grounded on an assessor's opinion of value rather than being observed from market transactions (i.e. the sales tax) (Youngman, 1994).

Conversely, when compared to other revenue generating streams, such as the income tax or the sales tax, the property tax has remained a preferred method of revenuesource generation for local taxing authorities. The reasons for this preference are threefold: First, the link between the tax and the provision of local services is relatively demonstrable. Second, the real property tax is a relatively stable funding source. Finally, the tax is imposed on an immobile tax base, making tax avoidance particularly difficult (Youngman, 1994).

Figure 1

Average Property Tax in Dollars: Five-Year Average 2007 -2011

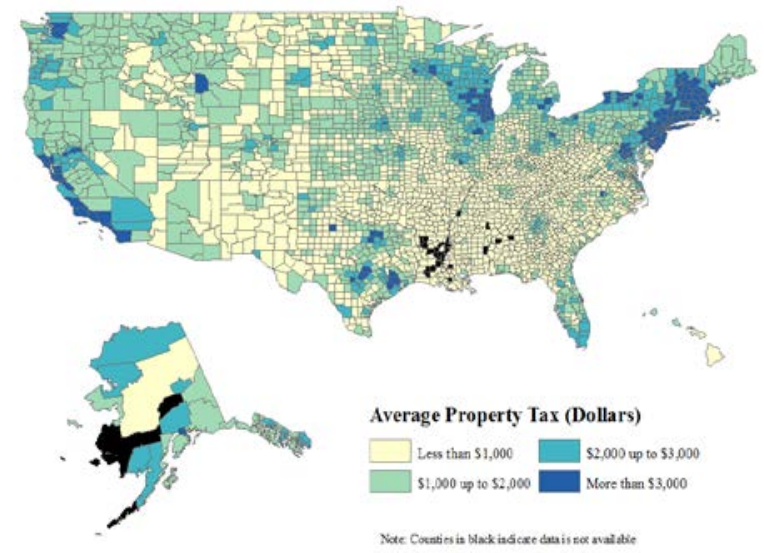

Source: Harris, B.H., \& Moore, B.D., (2013). Residential Property Taxes in the United States. Research Report. Washington DC, Urban-Brookings Tax Policy Center 
Today, the real property tax is administered in a complex environment in which a number of economic, political, legal, and administrative factors converge. The revenues derived from the real property tax serve as the primary funding source for a variety of critical local public service systems including public schools, local government agencies, and emergency services. Viewed from the perspective of decreasing federal and state fiscal support for local governments, the importance of the property tax takes on an even greater significance.

As a local revenue-generating process, the property tax involves multiple stakeholders each with their own social, political, and economic agendas. For the property tax to work and to continue to fund these critical services, stakeholders, particularly taxpayers, have to "buy-in-to" or accept the notion, that the tax is serving its intended purpose and that the tax burden is being distributed equally. As a result, property tax administration systems often operate under the auspices of equity and efficiency.

\section{Property Tax Administration Process}

In the United States, the real property tax is not a single tax per se, but a complex collection of taxes with thousands of local variations (Netzer, 1966). Political and legal inclinations in the United States have resulted in the property tax becoming a decentralized institution subject to various state and local laws. While the use of the property tax has been eclipsed by the adoption of income and sales tax mechanism at the state level, it has remained a significant revenue generating mechanism for local governments. Among the various tax mechanisms available, the property tax is the only 
tax utilized in every state of United States, the District of Columbia and in every Canadian province (IAAO, Standard on Property Tax Policy, 2010).

Despite the wide range of property tax systems in the United States, the local property taxation process can be generalized by a nine-step progression. The first step involves the establishment of the property tax base. Here, the property assessor or appraiser estimates the assessed value for all properties located within their respective jurisdictions, utilizing a technique known as mass appraisal ${ }^{1}$. At the second step, local taxing authorities set millage or tax rates based upon their predicted budgetary needs. The millage rates are then applied to the value of the respective property tax base, to determine the property tax. Subsequently, the tax roll is approved or disapproved by an oversight agency.

In some instances, the property assessor, in conjunction with the local taxing authorities, distributes formal notices to inform property owners of their property value and to provide an example of the possible tax bill. At this step, property owners who have questions about, or are in disagreement with their property assessments, are provided an opportunity to have an informal conference with their local property assessor. If the property owners are not satisfied with the results of the informal conference, the property owners may proceed to a sixth step, in which they may file a formal appeal. During the seventh step, the tax collector prepares the tax bills and mails them to the property owners. At the eighth step, the tax collector receives and process all

\footnotetext{
${ }^{1}$ Mass appraisal is the systematic evaluation of groups of properties, as of a given date, using standardized procedures and statistical testing. As opposed to a single appraisal, which involves the evaluation of a single property. Mass appraisals are primarily conducted by ad-valorem appraisers. While single appraisals are often conducted by private sector or fee appraisers.
} 
property tax payments and refunds. The final phase involves the funding of government services, in which the collected property tax revenues are distributed to the various taxing authorities, which have levied the tax. For each state, the property tax administration process is based upon established state statutes and is conducted at an established pace, such as an annual or bi-annual basis.

Figure 2

Property Tax Administration Process

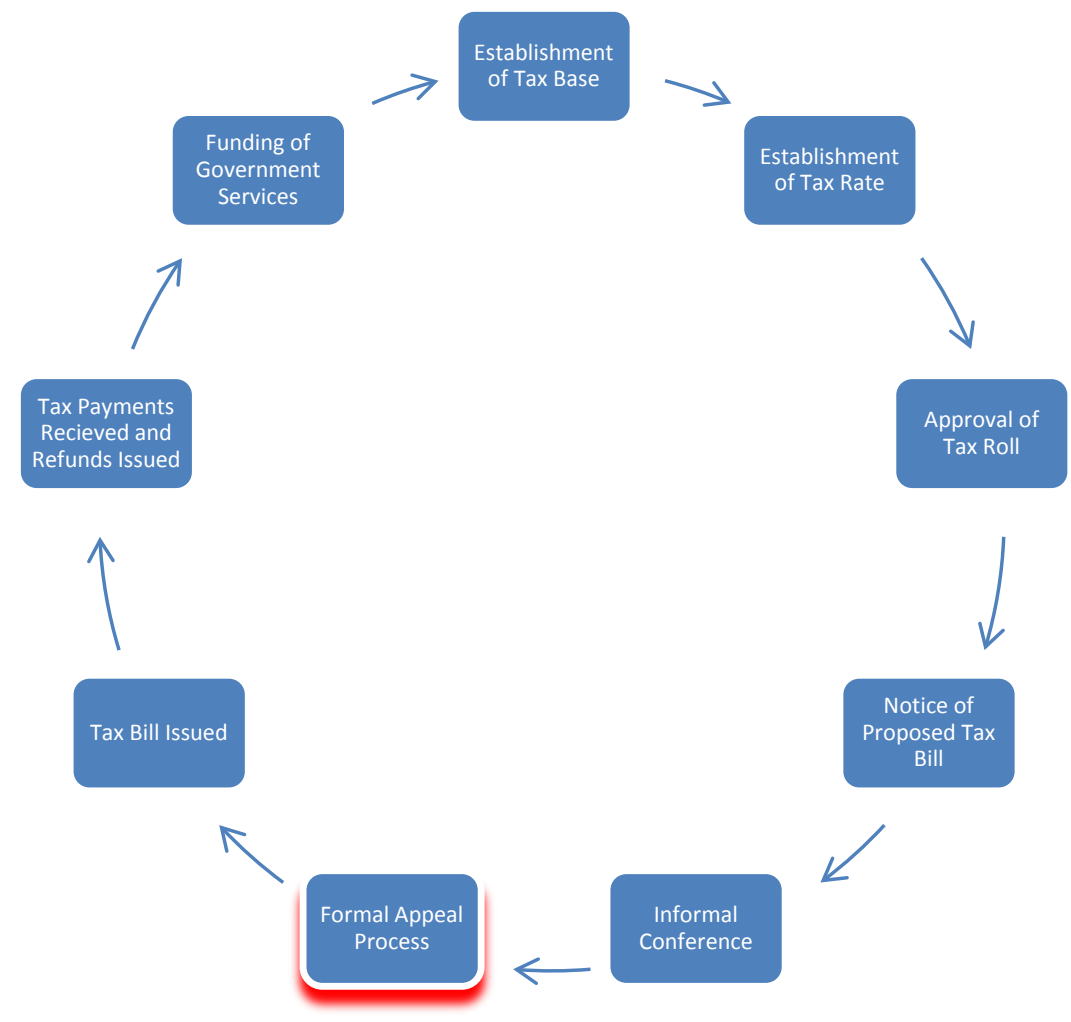

The sixth step in the local property tax administration process, the formal appeal process, is the focus of this study. The formal appeal processes, also known as property tax assessment review and appeal systems, are typically administered by a third party and serve several important functions. Property tax assessment review and appeal systems 
are quasi-administrative-judicial mechanisms intended to assure the public that property assessments are correct, fair, and equitable (International Association of Assessing Officers, 2001). In addition, property tax assessment review and appeal systems serve to ensure assessment uniformity, maintain and maximize the revenue base, monitor assessment officials, and ensure compliance with state and local legal standards (Pops, 1985).

Despite these seemingly important functions, there is a paucity of research related to property tax assessment review and appeal systems. Traditionally, property tax literature has focused on mass appraisal techniques, assessment administration, and tax policies. While these topics have been well documented, property tax assessment review and appeal systems have, in large part, been neglected by academic and policy-making circles.

\section{$\underline{\text { Identification of Problem }}$}

Recently, media outlets across the United States have chronicled an increase in the occurrence of property owners participating in the property tax appeals process. The increases in property tax appeals, in some instances, have resulted in a backlog of hearings and substantial reductions in the value of local tax bases. In Clark County Nevada, the Las Vegas Review-Journal reported that,

This year's record number of appeals on property values has pushed the countywide tax revenue loss to an estimated $\$ 435$ million, and the bleeding isn't over...[s]o far, the appeals have shaved $\$ 11$ billion off the county's total taxable values, shrinking them to $\$ 16.2$ billion from $\$ 27.2$ billion, Shafe [assistant assessor] said (Wyland, 2010).

Similarly, in South Florida, the Sun Sentinel reported,

Tax appeals have been pouring into government offices throughout Florida, fueled by the real estate boom and crash and a highly profitable cottage industry of tax representatives. So far this year, Broward and Palm Beach counties have reduced property values by more than $\$ 2.5$ billion as a result of appeals (Kestin \& Maines, 2010). 
In the District of Columbia, the District’s Board of Real Property Assessments and Appeals reported an eighty-five percent increase in the number of appeals from 2007 to 2010, resulting in a loss of approximately $\$ 51$ million (Marimow, 2010). In South Florida, the South Florida Water Management District, which is responsible for managing and protecting the water resources of the region, experienced a revenue shortfall of \$5 million for the 2012 tax year, based on reductions achieved at Miami-Dade County’s Value Adjustment Board (Rodriguez-Taseff, 2013).

The impacts of these appeals on local coffers are not always contingent upon a high volume of cases. In some instances, a single appeal, ruled in favor of the taxpayer, can have a tremendous impact on a local budget. Take for example, Charlton County, Georgia population 10,282 (Census Bureau, 2010). In this instance, a privately owned prison operator successfully appealed its property assessment, which resulted in a reduction of assessed value from $\$ 97$ million to $\$ 55$ million (Jackson, 2010). The successful appeal reportedly cost the city, county and school system at least $\$ 730,000$ in anticipated tax revenue (Jackson, 2010).

An unexpected loss of revenue, often taking place years after the original assessment, can leave taxing authorities scrambling to cover costs. Recently, a township in New Jersey introduced a $\$ 3.75$ million bond ordinance in order to cover a portion of the $\$ 30$ million in refunds due to property owners that were successful in their appeals (Lamendola, 2010). Other stakeholders, in the property tax process, have resorted to litigation to combat revenue shortfalls associated with the property tax appeal process. In Miami-Dade County Florida, the local school board has considered joining a local 
teachers union’s lawsuit against the county mayor to recover approximately $\$ 40$ million in lost revenue (Veiga \& Nehamas, 2015).

The rise in the number of participants in the assessment review and appeal process and its subsequent effect on local property tax bases presents some interesting questions that have yet to be completely addressed in an empirical study, for example: Who is utilizing the appeal system? Are there certain characteristics that these taxpayers share? Is there a discernible pattern of success for certain property types? How do the patterns of use and success in assessment review and appeal systems affect the distribution of the overall tax burden? For instance, are there indications of regressivity (lower-valued homes bear a greater tax burden) or progressivity (higher-valued homes bear a greater tax burden) following the appeal process? This dissertation addresses these questions.

\section{Research Questions, Hypotheses, and Methodology}

From the research questions and previous empirical literature concerning property tax assessment review and appeal systems, the following hypotheses have been developed:

Question 1: Are there certain demographic and socio-economic factors, which influence a property owner's decision to file an appeal?

Hypothesis 1: On average, demographic, and socio-economic factors such as education, income and race increase the probability that a property owner will appeal their property assessment.

Question 2: Are there construction, assessment, and/or market characteristics that influence a property owner’s decision to appeal? 
Hypothesis 2: On average, construction factors have an inverse relationship to the decision to appeal, while assessment and market factors have a direct relationship to the decision to appeal.

Question 3: How do construction, assessment, market factors, and professional representation influence the probability of a successful appeal?

Hypothesis 3: On average, construction, assessment, market factors, and professional representation influence a reduction in market value.

Question 4: How do the patterns of use and success in the property tax appeal process affect the overall distribution of the tax burden?

Hypothesis 4: The pattern of use and success improves the overall distribution of the tax burden.

The first two research questions examine the variables that may influence a property owner's decision to participate in the property tax appeal process, while the third examines variables that influence a reduction in market value. All of the research questions are examined through the analysis of available datasets. The survey provides the study with descriptive data about attributes of the property owners who choose to participate or forgo the opportunity to utilize the appeal system. Variables of interest include income level, education level, race, and age. In addition, questions related to property owners' opinions concerning the property tax appeal process and local government service delivery are included in the survey. In addition to the survey instrument, data made available from the various counties’ Value Adjustment Boards, the Florida Department of Revenue, and United States Census Bureau have been combined to examine socio-economic/demographic information at the tract level of analysis. 


\section{Theoretical Models}

Based on previous research concerning property tax review and appeals systems and property tax assessment uniformity, two models have been developed for this study (Paglin \& Fogarty, 1972; Geraci \& Plourde, 1976; Kochin \& Parks, 1984; Giertz \& Chicoine, 1990; Eom, 2008; Weber \& McMillen, 2006; Plummer, 2010; Doerner, 2012). These models examine the decision to appeal and the percentage change in value of a successful appeal, as dependent variables. It is postulated that the variable interactions within these models, will reveal patterns allowing the researcher to identify who utilizes assessment review and appeal systems, the magnitude of success, and whether certain characteristics of an assessment review and appeal system will produce correct, fair, and equitable results.

Decision to Appeal = f(structural characteristics, assessment practices, market activity, economics, demographics)

Effectively, the study treats the decision to appeal as a dependent variable, with the characteristics of the property owners and the characteristics of their respective properties serving as independent variables. Other important independent variables include data related to the local real estate market and local assessment practices. Data related to the local real estate market and local assessment practices has been obtained from various government entities including the local property appraiser's office, the state department of revenue, and the county clerk's office. 
Value Change $=f($ property characteristics, assessment practices, market activity, professional representation)

In addition to the decision to appeal, the reduction in market value for appealed properties is explored. Research question three examines the determinants of a successful appeal. Here, the percentage change in market value serves as the dependent variable. Similar to the decision to appeal model, independent variables include property characteristics, real estate market data, and local assessment practices. However, three additional variables are included to account for construction quality, professional representation, and endogeneity.

Finally, in addition to determining the variables that stimulated property owners to appeal and the likelihood of a successful appeal, the study examines whether the outcomes of the appeal process significantly alter the tax burden. For research question four, the objective is to determine whether the appeal process shifts the burden to lowervalued properties (fostering a regressive tax system), shifts the burden to higher-valued properties (fostering a progressive tax system) or whether there is not significant change in the tax burden (fostering a proportional tax system).

Purpose of the Study

The purpose of this dissertation is four-fold: 1) to examine who participates in the property tax appeal process and the variables that stimulated participation, 2) to determine who is successful and to identify variables which may explain why these participants are more successful than others, 3) to determine whether the appeal outcomes are proportional, regressive, or progressive; and 4) to contribute to the property tax administration literature by producing a comprehensive empirical examination of an 
assessment review and appeal system. This dissertation is intended to describe, explain, and predict the relationships of various factors pertinent to the property tax review and appeal systems. As such, the first and second objective is to provide descriptive data concerning the property tax appeal process. The third objective is based on the presumption that the ultimate goal of an assessment review and appeal system is to ensure uniformity, which legitimizes the overall property tax system. This presumption will be tested by applying and extending methods that have been traditionally applied to the activities of the assessor's office. Specifically, studies of property tax administration have relied upon ratio studies and complex uniformity analyses to measure equity and identify the determinants of uniformity. The final objective is to present an empirically based analysis of a seldom-studied subject. Considering the assessment review and appeal system is intended to legitimate the primary own-source revenue systems of local governments, an attempt to determine whether the system is reaching its objectives is warranted.

\section{Significance of the Study}

Many researchers (Paglin \& Fogarty, 1972; Geraci \& Plourde, 1976; Kochin \& Parks, 1984; Giertz \& Chicoine, 1990; Eom, 2008) have examined the determinants of uniformity in property tax administration. However, the research has largely focused on the administrative and organizational factors that influence property tax uniformity in terms of the specific activities of the assessor's office. Historically, there has been very little consideration to whether the activities of the institutions created to ensure uniformity (and subsequently legitimate local taxing systems) are meeting that goal. 
Many of the earlier studies dedicated to this topic were largely judicially oriented (Youngman 1989, 1994) and/or descriptive in nature (Pops, 1985; Wilde, 2001).

However, there has been a burgeoning movement to focus on the property tax appeal phenomenon, although the motivations and methodologies for studying the subject have varied greatly (Ratcliff \& Pennick, 1983; Blocksidge \& Downing, 1989; Downing \& Blocksidge, 1990; Weber \& McMillen, 2006; Firoozi, Hollas, Rutherford \& Thomson, 2006; Plummer, 2010; Hissong \& Hawley, 2012; McMillen, 2010; Doerner \& Ihlanfeldt, 2014). A review of the property tax administration literature has revealed a limited number of empirical studies related to assessment review and appeal systems, which in turn, presents an excellent opportunity to contribute to property tax administration literature.

\section{$\underline{\text { Research Design }}$}

The research involves a multiple-county study, which examines two Florida counties Broward and Duval, over a three-year period. The study utilizes an integrated mixed-method design, which relies upon a custom-designed survey of single-family property owners, as well as a quantitative analysis of single-family property appeal results. The guiding hypotheses are tested at various levels of observation ranging from the county, to the census tract, to the parcel level. The primary units of analysis are the findings of the survey respondents, which are aggregated to the county level and the appeal results from each county’s value adjustment board.

The State of Florida serves as a good candidate for this analysis because it utilizes a single level (county) of assessment review and appeal as opposed to other states, which may employ multiple-level (municipal, county, and state) appeal mechanisms. 
Additionally, limiting the research to a single state controls for regional differences and different state laws pertaining to assessment practices. Broward and Duval counties were selected because each county is representative of the larger metropolitan areas of the state, yet represent areas with different macro and micro-economic influences.

In order to address the stated research questions, the dissertation involved three stages of analysis. The first stage addressed research questions one and two, by examining variables that may spur property owners to appeal their properties. Here, appealed single-family parcels (test group) were identified and compared to a random sample of non-appealed single-family parcels (control group). This comparison provides data as to whether appeals are coming from certain areas in a respective jurisdiction and whether the owners of these appealed properties share certain socio-economic and/or demographic characteristics. Similarly, a comparison is made in regards to real estate market activity, assessment characteristics, and a respective parcel's physical characteristics.

The second stage addresses research question three. Here, the inputs and outputs of the assessment review and appeal process are examined. The inputs are represented by the appealed properties and their respective assessed values. The outputs are represented by whether the assessed values of the appealed properties are reduced, increased, or remain the same. During the second stage, the properties being appealed are identified and their respective rates of success are determined.

The third stage addresses research question four and focuses on the outcomes of the assessment review and appeal process. Outcome measures traditionally focus on program results. As previously noted, the intended outcome of property tax assessment 
review and appeal systems is to assure the public that property assessments are correct, fair, and equitable. As a result, the third stage of this analysis examines whether the outcomes of the assessment review and appeal process produce fair and equitable results.

As previously mentioned, the study utilizes an integrated mixed-method design, which relies upon a survey of single-family property owners, as well as a quantitative analysis of appeal results. For the research design, the population is all single-family properties located in two select Florida counties, for a particular assessment year. The sampling frame focuses on all single-family properties subject to appeal in the select Florida counties. The primary data sources for the analysis include single-family property owners in the respective county, the Florida Department of Revenue, the county assessors' offices, and the county value adjustment boards. While, other data sources include county and state budget documents, the United States Census Bureau, the United States Bureau of Economic Analysis, and the International Association of Assessing Officers.

The data analyses were conducted using STATA ${ }^{\circledR}$ version 13.1. The primary regression procedures utilized were the Firth logit and the Heckman two-stage maximum likelihood regression analyses. Secondary procedures include basic frequency distributions, cross tabulations, and the use of ArcMAPS ${ }^{\circledR}$ version 10.2 to create thematic maps.

\section{$\underline{\text { Summary of Results }}$}

The results of the integrated mixed-method research design varied. The responses to the survey were low, rendering the data statistically unreliable. As result, the data 
gleaned from the survey was limited to providing contextual evidence of property owners' opinions concerning property taxes and county government services.

The analyses of the decision to appeal data indicated that properties that are more expensive were more likely to be appealed, properties with homestead exemptions were less likely to be appealed, and that properties initially excluded from uniformity analyses were more likely to be appealed. In addition, appeals were clustered in certain geographic areas; however, these areas did not always experience a greater percentage of the value changes.

The value change analyses results were largely mixed. Interestingly, professional representation did not result in a greater reduction in a property's value. Other relationships between the various variables were discovered, but often with weak predictive ability.

More useful were the findings of the assessment uniformity analyses. The results indicated that the appeals mechanisms in both counties improved assessment uniformity over the study period. On average, appealed properties exhibited greater indications of horizontal and vertical inequities, as compared to non-appealed properties. After, the appeal process was completed; the traditional indicators of horizontal and vertical were in large part, improved in both counties.

\section{$\underline{\text { Scope and Limitations }}$}

A few limitations of this study should be acknowledged. First, the external validity of the results may be questioned because the study will be limited to the State of Florida. As demonstrated in the literature review, property tax administration systems in the United States are largely decentralized institutions strongly influenced by states laws 
and unique local conditions. As a result, the ability to make generalizations of the study may be influenced by unique program features and the setting. Second, the quantitative data obtained in this study depended in large part on secondary sources including the United States Census Bureau, the Florida Department of Revenue, county property appraiser offices, and the county clerks' offices. Consequently, errors in data collection may not be easily detected. Lastly, the survey data is based on a collection of cross sectional data, as such, the data is subject to heteroskedasticity, and the ability to eliminate alternative hypotheses is difficult.

\section{Organization of the Dissertation}

This dissertation begins with a chapter that examines the concept of equity and its role in property tax administration. Chapter 3 provides a synopsis of the contemporary literature related to assessment review and appeal systems. Chapter 4 presents the research design and methodology topics include: the guiding hypotheses, the data sources and characteristics, the selection criteria and instrumentation of the variables, and the utilized analysis techniques. Chapter 5 presents a brief synopsis of each county, along with the results of a property owner survey. Chapter 6 and 7 discusses the results of the analyses of the appeals data for each county. Finally, chapter 8 summarizes the findings, presents the conclusion, and provides recommendations for further research. 


\section{CHAPTER II \\ EQUITY AND PROPERTY TAXATION}

\section{$\underline{\text { Structure and Overview }}$}

This section examines the concept of equity and its role in property tax administration. The section begins with a discussion of the two primary principles by which tax systems are considered, the user-benefit principle and the ability-to-payprinciple. The discussion then shifts to the specific relationship between equity principles and the property tax. Next, the traditional metrics for determining equity in property tax administration are presented. Finally, the section addresses how the concept of equity has been operationalized into the property tax administration process and presents an example of such an occurrence.

\section{Equity Principles}

The concept of tax equity has largely been shaped by two prevailing standards, the user-benefit principle, and the ability-to-pay-principle. Under the user-benefit principle, all tax burdens are to be distributed in the same proportion as the benefit derived from the government. The user-benefit principle has been espoused by philosophers such as Thomas Hobbes and John Locke (Levy, 1995). An example of a user-benefit tax is the gasoline tax. The gasoline tax is an excise tax, in which the derived revenues are dedicated to funding road projects. To the extent that the amount of gasoline purchased is a proxy for how much a person uses the public roads, the gasoline tax is considered a user-benefit tax (Levy, 1995).

The ability-to-pay-principle is based upon the notion that the highest taxes should be levied on those with the greatest ability to pay. As opposed to the user-benefit 
principle, the ability-pay-principle is not based upon benefits received but upon the idea of equal sacrifice. The ability-to-pay-principle has been espoused by the likes of JeanJacques Rousseau, Jonathan Bentham, and John Stuart Mills (Levy, 1995). An example of a tax based on the ability-to-pay principle would be the income tax, in which, the amount of taxes a person pays increases as their incomes increases. The ability-to-payprinciple involves two measures for assessing fairness; horizontal equity and vertical equity. Horizontal equity holds that economically situated taxpayers occupying similar positions should pay equal taxes, while vertical equity proposes economically diverse taxpayers should pay the same proportion of taxes.

The excise tax and the income tax represent opposite ends of the userbenefit/ability-to-pay spectrum, while the property tax falls somewhere in between. The fact that real property is immobile has led to some arguments that the property tax is a user-benefit tax, in which the tax payments are rendered for public services received (i.e. fire services, police protection, etc.). Conversely, it has been historically argued that the property tax is an ability-to-pay tax, in which the assessed value of a property serves as an indication of the owner's ability to pay (Levy, 1995). However, periods of rapid appreciation in the real estate market have largely challenged that perspective. In modern society, the income tax has become the closest approximation to the ability-to-pay principle.

\section{Equity in Property Tax Administration}

The need for equity is more than a philosophical or academic conundrum in the field of property tax administration. The U.S. Constitution and state constitutions, along with various federal and state courts, have mandated some form of equity in assessment 
practices. In the context of property taxes, equity is synonymous with assessment uniformity, which is defined as the degree to which assessments bear a consistent relationship to market value (IAAO, Standard on Property Tax Policy, 2010). A lack of assessment uniformity can result in an inequitable tax burden among property owners, diminish the ability to generate local revenues, and creates economic distortions within and among taxing jurisdictions (Netzer, 1966; Lynn, 1969). To determine whether assessments are equitable, practitioners have traditionally focused on three types of assessment equity: 1) the level of assessment 2) horizontal equity and 3) vertical equity (Sirmans, Diskin, \& Friday, 1995; Twark, Eyerly, \& Downing, 1989). Traditional Indicators of Assessment Uniformity

As previously mentioned, a unique and important characteristic of the property tax is that it is based upon an assessor's opinion of value, rather than being directly observed from market transactions. The assessor is tasked with deriving a fair and equitable opinion of value for an entire jurisdiction based on a limited sample of qualified sales. In order to accomplish this task, property tax administrators have traditionally utilized three indicators of assessment uniformity; the level of assessment, the coefficient of dispersion, and the price related differential.

The level of assessment (LOA) is a ratio of assessed values compared to sales prices. The LOA indicates how close assessments are to the market value and can be utilized to analyze a single property or a group of properties ${ }^{2}$. The level of assessment analysis begins with the gathering of data concerning the sales price (SP) of recently sold

${ }^{2}$ Commonly, the level of assessment refers to a group of properties, while an assessment to sale ratio refers to a single property. 
properties in a respective market area or jurisdiction ${ }^{3}$. Next, the assessed values (AV) that were estimated by the assessor, prior to the sale, are compared to the actual sales prices (SP) of the individual properties. The comparison results in the level of assessment metric. The assessment-to-sale ratio provides the assessor with information regarding the assessment levels in a taxing jurisdiction. For example, a single-family home may have recently sold for $\$ 100,000$ while the previous assessed value indicates $\$ 80,000$. The assessment-to-sale ratio indicates .80 , thus the level of assessment for the single-family home is eighty percent of market value. In a full market value jurisdiction, the assessed value for that particular property would be considered under-assessed. The level of assessment analysis represents a basic metric for determining assessment uniformity. The IAAO advocates full market value as the level of assessment (IAAO, 1999). However, there remains a large disparity in the levels of assessment among the various states. The disparity in the levels of assessment can be attributed, in large part, to the decentralized nature of property tax administrative systems in the United States. Some states provide specific levels of assessment through state statutes, while other states’ levels of assessment are established through administrative or oversight agencies (IAAO, 2011).

3 Sales must be carefully considered for inclusion in assessment studies (Geraci \& Plourde, 1976). As, Geraci and Plourde note, "Sales are neither random drawings from the universe of properties nor perfect indicators of true (unobservable) market value (1976).” 
Table 1

Level of Assessment by State

\begin{tabular}{|c|c|c|c|}
\hline State & $\begin{array}{c}\text { Level of } \\
\text { Assessment }\end{array}$ & State & Level of Assessment \\
\hline Alaska & 100 & Nebraska & 100 \\
\hline Arizona & 10 & Nevada & 35 \\
\hline Arkansas & 20 & New Hampshire & 100 \\
\hline California & Acquisition Value & New Jersey & 100 \\
\hline Colorado & 7.96 & New Mexico & 100 \\
\hline Connecticut & 70 & New York & Varies by jurisdiction \\
\hline Delaware & 60 & North Carolina & 100 \\
\hline District of Columbia & 100 & North Dakota & 100 \\
\hline Florida & 100 & Ohio & 100 \\
\hline Georgia & 40 & Oklahoma & $11-13.5$ \\
\hline Hawaii & 100 & Oregon & Other \\
\hline Idaho & 100 & Pennsylvania & 100 \\
\hline Illinois & 33.33 & Rhode Island & 100 \\
\hline Indiana & 100 & South Carolina & 4 \\
\hline Iowa & 45 & South Dakota & 100 \\
\hline Kansas & 11.5 & Tennessee & 25 \\
\hline Kentucky & 100 & Texas & 100 \\
\hline Louisiana & 10 & Utah & 100 \\
\hline Maine & 100 & Vermont & 100 \\
\hline Maryland & 100 & Virginal & 100 \\
\hline Massachusetts & 100 & Washington & 100 \\
\hline Michigan & 50 & West Virginia & 100 \\
\hline Minnesota & Varies & Wisconsin & 10 \\
\hline Mississippi & $10-15$ & Wyoming & 9.5 \\
\hline Missouri & 19 & & \\
\hline
\end{tabular}

Source: Significant Features of the Property Tax. http://www.lincolninst.edu/subcenters/significantfeatures-property-tax/Report_State.aspx. Lincoln Institute of Land Policy and George Washington Institute of Public Policy.

A subsequent and more advanced analysis is to measure equity across properties.

Horizontal equity posits that similar properties share an equal tax burden. In this instance, the level of assessment should be the same for similar properties in a jurisdiction. The most common measure of horizontal equity is the coefficient of dispersion (COD). The COD is calculated by finding the average of all absolute percentage deviations from the median: 


$$
C O D=\frac{\left(\frac{1}{N}\right) \sum_{i=0}^{n}\left|R_{i}-R^{\text {med }}\right|}{R^{\text {med }}} \times 100
$$

where $\mathrm{N}$ is the number of properties in the sample, $\mathrm{R}_{i}$ is the assessment-to-price ratio (AV/SP) for property $i, \mathrm{R}^{\text {med }}$ is the median of these ratios within the jurisdiction.

The COD is interpreted as the average percentage difference of all property assessment ratios from the median assessment ratio. The higher the COD, the greater the scattering of individual assessments around the jurisdictional average, which in turn, indicates a greater degree of horizontal inequity among properties.

\section{Table 2}

\section{Ratio Study Uniformity Standards*}

\begin{tabular}{|l|l|l|}
\hline Type of Property - General & Type of Property - Specific & COD Range** \\
\hline $\begin{array}{l}\text { Single-family residential } \\
\text { (including residential condos) }\end{array}$ & Newer or more homogeneous areas & 5.0 to 10.0 \\
\hline Single-family residential & Older or more heterogeneous areas & 5.0 to 15.0 \\
\hline Other residential & $\begin{array}{l}\text { Rural, seasonal, recreational, } \\
\text { manufactured housing, 2-4 unit } \\
\text { family housing }\end{array}$ & 5.0 to 20.0 \\
\hline Income-producing properties & $\begin{array}{l}\text { Larger areas represented by large } \\
\text { samples }\end{array}$ & 5.0 to 15.0 \\
\hline Income-producing properties & $\begin{array}{l}\text { Smaller areas represented by smaller } \\
\text { samples }\end{array}$ & 5.0 to 20.0 \\
\hline Vacant land & & $\begin{array}{l}\text { Varies with local } \\
\text { conditions }\end{array}$ \\
\hline $\begin{array}{l}\text { Other real and personal } \\
\text { property }\end{array}$ & & not represent
\end{tabular}

These types of property are provided for guidance only and many not represent jurisdictional requirements.

*Appraisal level for each type of property should be between 0.90 and 1.10, unless stricter local standards are required.

**CODs lower than 5.0 may indicate sales chasing or non-representative samples. Source: International Association of Assessing Officers. (2010), Standard on Ratio Studies. Kansas City, MO. International Association of Assessing Officers. 
For example, suppose a taxing jurisdiction has a median assessment ratio of eighty-five percent, a tax rate of $\$ 7.50$ per $\$ 100$ of assessed value, and a COD of 25 . Thus, two similar properties, each with an assessed value of $\$ 100,000$ may experience property tax bills ranging from $\$ 4,781(.85 \times .075 \times \$ 100,000 \times .75)$ to $\$ 7,969(.85 \times$ $.075 \times \$ 100,000 \times 1.25)$ although the intended tax burden is $\$ 6,375(.85 \times .075 \times$ $\$ 100,000)$.

Another indicator of equity utilized by assessment practitioners is vertical equity. Vertical equity posits that properties at different price points share an equal or proportional tax burden. That is, the assessment ratio for higher valued properties should be the same as the assessment ratio for lower priced properties. In terms of assessment performance, vertical equity measures help to determine if an assessment system systematically leads to a regressive, proportional, or progressive property tax burden. The most common measure of vertical equity is the price-related differential (PRD). The PRD is an index centered on a value of one. The PRD is calculated by dividing the overall mean assessment-to-sales ratio of a jurisdiction by the sum of assessment divided by the sum of sale price (weighted average). Acceptable assessment practices will produce a PRD index between .98 and 1.03, which indicates that the assessment system is proportional (IAAO, 1999). If the PRD is less than .98, the assessment system is considered progressive. If the PRD is greater than 1.03, the assessment system is considered regressive.

Depending on the legal mandates within each taxing jurisdiction, state and local agencies utilize the level of assessment, coefficient of dispersion, and price-related differential metrics to approve or disapprove respective tax rolls at the end of every 
assessment cycle. If an assessor fails to meet the prescribed levels for each metric, the assessor and consequently the taxing jurisdiction risks not having the tax roll approved for that assessment period. The approval of the tax roll indicates that the overall assessment levels of the jurisdiction have been met, and presumably, that the majority of properties within the jurisdiction are being assessed uniformly.

\section{Uniformity in the State of Florida}

The State of Florida utilizes a decentralized property tax assessment system, in which, property tax assessment activities are primarily conducted at the county level, while oversight functions are conducted at the state level. Assessment appeal activities are chiefly conducted at the county level by quasi-judicial-administrative entities known as Value Adjustment Boards (VAB).

Here, the county property appraiser estimates the just value for all properties located within their respective jurisdictions, while the Florida Department of Revenue (FDOR) conducts annual reviews and bi-annual audits of each county property appraisers' assessment activities. Both entities are concerned with providing fair and equitable tax assessments to Florida's property owners.

All of Florida's property tax assessment activities are grounded in state constitutional law, statutes, case law, administrative rules, and regulatory activities. Section 1(d), Article VIII, of the Florida Constitution, provides for the voters of each county to elect a Property Appraiser every four years. In addition, Section 4, Article VII, of the Florida Constitution, requires a just valuation of all real property for ad valorem taxation. Furthermore, Florida Statutes specifically prescribe eight factors county appraisers shall consider in their determination of just value: 
(1) The present cash value of the property, which is the amount a willing purchaser would pay a willing seller, exclusive of reasonable fees and costs of purchase, in cash or the immediate equivalent thereof in a transaction at arm's length;

(2) The highest and best use to which the property can be expected to be put in the immediate future and the present use of the property, taking into consideration any applicable judicial limitation, local or state land use regulation, or historic preservation ordinance, and considering any moratorium imposed by executive order, law, ordinance, regulation, resolution, or proclamation adopted by any governmental body or agency or the Governor when the moratorium or judicial limitation prohibits or restricts the development or improvement of property as otherwise authorized by applicable law. The applicable governmental body or agency or the Governor shall notify the property appraiser in writing of any executive order, ordinance, regulation, resolution, or proclamation it adopts imposing any such limitation, regulation, or moratorium;

(3) The location of said property;

(4) The quantity or size of said property;

(5) The cost of said property and the present replacement value of any improvements thereon;

(6) The condition of said property;

(7) The income from said property; and

(8) The net proceeds of the sale of the property, as received by the seller, after deduction of all of the usual and reasonable fees and costs of the sale, including the costs and expenses of financing, and allowance for unconventional or atypical terms of financing arrangements. When the net proceeds of the sale of any property are utilized, directly or indirectly, in the determination of just valuation of realty of the sold parcel or any other parcel under the provisions of this section, the property appraiser, for the purposes of such determination, shall exclude any portion of such net proceeds attributable to payments for household furnishings or other items of personal property (Section 193.011, Florida Statutes).

In addition to the constitutional and statutory stipulations, section 195.027(1),

Florida Statues, requires the FDOR to prescribe rules and regulations for county property appraisers. These rules and regulations are enumerated in Chapter 12D of the Florida

\section{Administrative Code.}

The administrative entity responsible for reviewing the assessment activities of

the state's sixty-seven county appraisers and ensuring compliance with the various

statutory and regulatory requirements is the Property Tax Oversight Program (PTOP).

The PTOP is a sub-agency of the Florida Department of Revenue and its mission is to 
ensure fair and equitable administration; aid and assist local governments; and be accessible and responsive to Florida’s citizens.

The PTOP annually reviews each county’s tax roll, certifies each county's level of assessment, and provides professional certification and training for various entities involved in the property taxation process including: property appraisers, tax collectors, value adjustment boards, and local taxing authorities. Every year, the PTOP conducts a sales qualification study and reviews the tax roll of each county. Every two years, the PTOP conducts an in-depth audit of each county appraiser. During a non-in-depth review year, the PTOP reviews respective tax rolls by conducting sales qualification studies, utilizing sales ratio studies, and analyzing the overall composite level of assessment. During an in-depth review year, the PTOP employs various methods to extensively review the activities of the respective county appraiser. Methods of review include sale ratio studies, appraisal ratio studies, or a blend of sales and appraisal studies. Throughout the process, the PTOP utilizes, as guidance, the Ratio Study Uniformity Standards recommended by the International Association of Assessing Officers in conducting its various oversight functions (IAAO, Ratio Study Uniformity Standard, 2010).

The sales qualification study serves as the foundation, by which, the various assessment uniformity indicators are derived by the PTOP. During the sales qualification study, the PTOP conducts a random sample from all sales in a respective county, in order to determine whether those sales have been properly qualified for disqualified for consideration in a sales ratio study. If a county appraiser achieves less than a ninety percent match rate with the PTOP’s random sample, the county appraiser is issued a post- 
audit notification. Here, the county appraiser must then present credible, verifiable, and documented evidence justifying the discrepancy to the PTOP.

During the property taxation process, the county appraiser is statutorily required to stratify the tax roll into seven distinct property groups that constitute five percent or more of total assessed value in a respective county. These seven strata include:

- Residential property that consists of one primary living unit, including but not limited to, single-family residences, condominiums, cooperatives, and mobile homes.

- Residential property that consists of two or more primary living units.

- Agricultural, high-water recharge, historic property used for commercial or certain non-profit purposes, and other use-valued property.

- Vacant lots.

- Nonagricultural acreage and other undeveloped parcels.

- Improved commercial and industrial property.

- Taxable institutional or governmental, utility, locally assessed railroad, oil, gas, and mineral land, subsurface rights and other real property (Section 195.096(3)(a), Florida Statutes).

Depending on whether a respective county is in its audit year, the property stratums may be comprehensively reviewed by the PTOP. During an audit year, the respective county must produce minimum level of assessment of ninety percent for each prescribed stratum. During a non-audit year, the county appraiser is responsible for obtaining an overall composite level of assessment of ninety percent. The level of assessments within the property stratums are not reviewed by the PTOP. Once the sales qualification studies are completed, the PTOP then produces and reviews the traditional indicators of assessment uniformity for each county.

The PTOP reviews the LOA, COD, and PRD to obtain the uniformity indicators in a respective jurisdiction. While the State of Florida is classified as a full-market-value state (see Table 1), the level of assessment can range from eighty-five to hundred percent. 
Florida statutes require county appraisers to determine the present cash value of the property. However, the same statute also allows for the county appraiser to account for the net proceeds of a sale, which may include deductions for usual and reasonable fees and costs of sale, the costs and expenses of financing, and allowance for unconventional or atypical terms of financing (Section 193.011, Florida Statutes). The statute does not specifically enumerate what constitutes net proceeds. Thus, county appraisers are given some discretion to consider what entails the net proceeds from a sale. However, it is important to note, Florida Administrative Code 12D-8.002(4) specifies that if any reported percentage adjustments for net proceeds, exceed fifteen percent, documentation supporting these percentage adjustments must be provided to the FDOR.

After the LOA has been established, the PTOP then utilizes the COD and PRD standards prescribed by the IAAO, to determine assessment uniformity among the various property stratums (See Table 2). If a county appraiser does not meet the various requirements and is declared non-compliant by the PTOP, then state funds can be withheld and homestead exemptions may be lost in respective jurisdiction (F.S., 2010, x195.101).

Viewed from the context of the property tax administration process, the PTOP serves as a centralized internal quality control mechanism, designed to ensure fair and equitable administration, primarily at the beginning of the property tax cycle. In contrast, the assessment appeal and review system, known in Florida as the Value Adjustment Board, serves as an external quality control mechanism, intended to assure the public that property assessments are correct, fair, and equitable, at the end of the property tax cycle. The next chapter examines the assessment review and appeal system in greater detail. 


\section{CHAPTER III}

\section{ASSESSMENT REVIEW AND APPEAL SYSTEMS LITERATURE}

\section{$\underline{\text { Structure and Overview }}$}

This section examines the literature concerning property tax assessment review and appeal systems. The section begins with a brief discussion of the various property tax assessment review and appeal systems throughout the United States. The section then examines the literature, which has specifically addressed property tax assessment review and appeal systems. Finally, the section discusses the opportunity for supplementing the existing research base, through the examination of Florida's property tax assessment review and appeals system.

\section{Assessment Review and Appeal Typology}

The decentralized nature of property tax administration in the United States has resulted in an assortment of property tax assessment review and appeal systems. One minor indication of this fact, are the various nomenclatures associated with property tax assessment review and appeal systems; Property Tax Appeal Board (Illinois), Value Adjustment Board (Florida), Board of Equalization (California), Board of Tax and Land Appeals (New Hampshire), and the Tax Court (Maryland), to name a few. Despite the formidable assortment of property tax assessment review and appeals systems, there have been attempts to make some sense of the several systems utilized by state and local governments.

In an article entitled, “An Overview of Property Assessment Review and Appeal Systems,” Gerald Pops provides a typology of the various property tax assessment appeal and review systems within the United States. Pops begins with the proposition that the 
property tax administration process has four goals: to maximize revenues (primary), to bring about uniformity in the treatment of taxpayers (primary), to monitor the activities of tax officials (secondary), and to gain compliance with legal standards (secondary) (Pops, 1985). Pops posits that as a subsystem of property tax administration, property tax review and appeal systems share the same goals. Additionally, property assessment review and appeal systems share the same basic means to perform system functions:

- The legal standard of "market value" is the basis for making assessments.

- State tax agencies prescribe policy and rules for assessment, review, and appeal, and equalization functions for both state and local tax officials.

- State rules and policies relating to the review and appeal of assessments emphasize hearing processes in both administrative and judicial settings.

- Initial reviews and appeals are administered by local government agents; later reviews and appeals are administered by state agents.

Beyond these basic means, there is a significant deviation among states and localities as to the specific means to review appeals. Because assessment review and appeal system functions are shaped by various state laws, and involve many different stakeholders, there is a variety of structural forms available for carrying out the prescribed tasks (Pops, 1985). Pops proposes that assessment review and appeal systems can be generally categorized under four headings: the degree of centralization or decentralization, the degree of professional or political control, the degree of administrative or judicial organizational focus, and the degree of taxpayer participation (Pops, 1985). 
Figure 3

Pops Assessment Review and Appeal System Typology

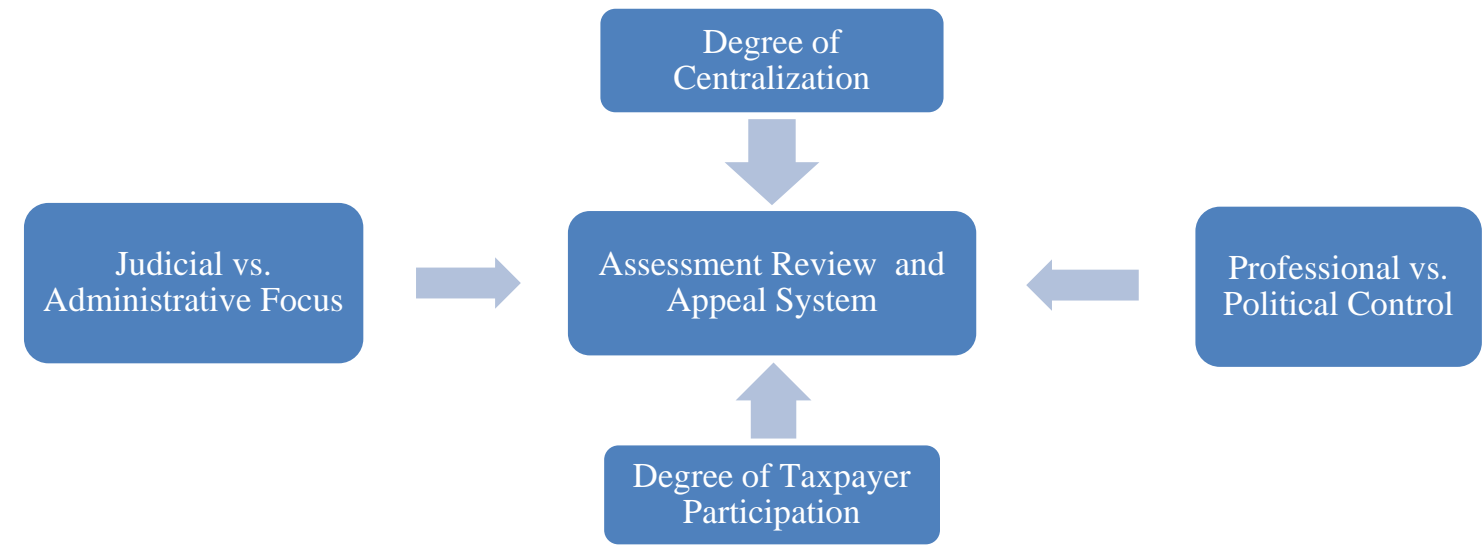

In addition to Pops’s administrative perspective, Joan Youngman, a senior fellow and chairperson of the Department of Valuation and Taxation at the Lincoln Institute of Land Policy has provided literature concerning the legal aspects of property tax assessment review and appeal systems. Youngman's Legal Issues in Property Valuation and Taxation, specifically examines the judicial issues related to property taxation through a comprehensive legal case study analysis (Youngman, 1994). However, Youngman's focus is primarily on various judicial conclusions related to property taxation with little analysis concerning the administration of the appeals process.

\section{Empirical Examinations of Appeal and Review Systems}

Through the years, there have been efforts to provide an empirical analysis of property tax assessment review and appeal systems, though, the earlier studies were largely descriptive in nature. In 1983, Ratcliff and Pennick co-authored "Property Tax Appeals and the Distribution of the Tax Burden: An Analysis of a Losing Battle in the Citizen’s Tax Revolt (1983).” Ratcliff, a sociologist, was concerned with whether the property tax revolts of the late 1970's were hastened by those who utilized the appeal 
system, who won, and how the tax burden was shifted by tax appeal process. The study examined cross-sectional data from property tax assessment appeals in St. Louis, Missouri conducted in 1974. Specifically, Ratcliff and Pennick examined how homeowners, as compared to large property owners fared in Missouri's property tax appeal system. The study revealed that a quarter of the appeals filed were homeowners, with the remainder of appeals consisting of commercial and industrial properties. "Property Tax Appeals and the Distribution of the Tax Burden," was largely a descriptive endeavor, which identified the appeal participants and whether or not they were successful their case. Success was indicated by whether or not any reduction was made regardless of the amount. Thus, a five-dollar reduction on a $\$ 100,000$ property would be considered successful as compared to a "no change in value" on a similar property type.

During the late 1980s, Downing and Blocksidge conducted a series of studies related to the appeal process for Allegheny County, Pennsylvania (Blocksidge \& Downing, 1989; Downing \& Blocksidge, 1990). The primary purpose of these studies was to determine if the appeal process improved equity. Both studies were largely descriptive in nature. The first study utilized times series data from 1985 through 1986. The study focused on vacant land and attempted to determine the number of appeals filed by land use, the disposition of the number of appeals by land use, and the dollar impact of the net change as result of appeals by year. Additionally, the authors examined the number of properties under appeal, which subsequently sold, to determine the effect that the disposition of the appeal had on the level of assessment and the uniformity of assessment. The authors determined the appeal process had an insignificant effect on the tax base and a negligible effect on equity (Blocksidge \& Downing, 1989). 
Downing and Blocksidge's second study utilized panel data from 1985 through 1989. In this instance, the second study focused on single-family residences, as opposed to vacant land, which was the focus of the first study. Similar to the first study, the authors examined the difference between assessment sales ratios for the appealed properties that sold, from all the rest of the properties that sold. The authors concluded the higher value single-family residences had a higher percentage of appeals and a higher percentage properties sold. Again, the authors concluded that the appeal process had no effect on regressivity (Downing \& Blocksidge, 1990).

More recently, there has been a resurgence in the examination of assessment uniformity within the context of assessment appeal and review systems, albeit, the various scholars' motivations and methodologies for examining the phenomena differ in various ways. Some scholars have examined the relationships between market activity, administrative structures, and property tax uniformity (Weber \& McMillen, 2010; Doerner, 2012; Doerner \& Ihlanfeldt, 2014). Other scholars explored the topic in terms of information asymmetry (Firoozi, Hollas, Rutherford \& Thomson, 2006). While other scholars were interested in the effect that land-to-value ratios have on the appeal process, or revisited Ratcliff and Pennick's question as to whether formal protests serve as a proxy for taxpayer unrest (Plummer, 2010; Hissong \& Hawley, 2012). In contrast to the earlier studies, the more recent studies have demonstrated a more advanced analysis of assessment appeal and review systems by providing theoretical models and including various regression and spatial analyses.

In 2010, in a study entitled “Ask and Ye Shall Receive? Predicting the Successful Appeal of Property Tax Assessments,” Rachel Weber and Daniel McMillen examined 
how the relative lack of comparable sales in a neighborhood influenced the frequency of assessment appeal applications and their likelihood of success. Here, the authors utilized a Cook County (Chicago), Illinois panel data set of residential property appeals submitted and decided during the years of 2000, and 2003.

The authors developed two models to determine the likelihood that a property would be appealed (Appeals Model) and the likelihood of success (Success Model). Because the decision to appeal is a binary choice, the authors utilized separate probit models to measure the probability that property owners appeal their assessment (Appeals Model). Sensing an issue wherein the unobserved variables that influence the decision to appeal may be expected to determine the success of an appeal once made, the authors developed the models in the following functional form:

No Appeal

Successful Appeal

Unsuccessful Appeal

$$
\begin{gathered}
\text { Probability } \\
1-\Phi\left(X_{1} \beta_{1}\right) \\
\Phi_{2}\left(X_{1} \beta_{1}, X_{2} \beta_{2}, \rho\right) \\
\Phi_{2}\left(X_{1} \beta_{1},-X_{2} \beta_{2},-\rho\right)
\end{gathered}
$$

where $\Phi$ was the standard normal distribution function, $\Phi_{2}$ was the bivariate normal distribution function, $\mathrm{P}$ is the correlation between the errors of the two equations, and $\mathrm{X}_{2}$ was a vector of variables, which were likely to affect the success of an appeal.

The authors grouped the explanatory variables into four categories: 1) a property's structural characteristics, 2) assessment characteristics, 3) neighborhood real estate market characteristics, and 4) neighborhood demographic characteristics. The appeals model emphasized neighborhood demographic assessment characteristics. While, the success model focused on structural and neighborhood real estate market characteristics. 
The authors found that appeals applicants were more likely to come from census tracts with high median home values and assessments and those with a greater share of homeowners. In addition, an increase in comparable sales in a given market resulted in fewer appeals applications and decreased the likelihood that a property owner would be successful in his or her appeal (Weber \& McMillen, 2006).

During the same time, Firoozi, Hollas, Rutherford, and Thomson explored the topic of assessment uniformity in assessment appeal and review systems with an emphasis on information asymmetry. Specifically, the authors examined whether property tax consultants exploited information asymmetry to gain a lower appraised value for their homes as compared to neighboring houses. The objectives of the study were two-fold: First, to examine whether an information separation between property tax consultants and other homeowners could be measured by differences in assessed values. Second, the authors attempted to determine whether "Board Determined" values differed from "Certified" values.

To test the hypothesis, the authors utilized a "fixed effects" regression model, which employed the common appraisal approach of the log-linear specification:

$$
\ln \left(V_{i j}\right)=\alpha_{j}+\beta^{\prime} X_{i j}+\varepsilon_{i j}
$$

where, $\ln \left(V_{i j}\right)$ is the natural $\log$ of the appraised value for home $I$ at location $j, \varepsilon_{i j}$ is a classical disturbance with $\mathrm{E}\left[\varepsilon_{i j}\right]=0$ and $\operatorname{Var}\left[\varepsilon_{i j}\right]=\sigma_{\varepsilon}^{2}, \mathrm{X}_{\mathrm{ij}}$ is a matrix of attributes describing home $i$ at location $j, \beta^{\prime}$ is a vector of regression coefficients, and $\alpha_{j}$ are the location intercepts. Utilizing a list of licensed property tax consultants in Bexar County (San Antonio) Texas, the authors were able to identify 46 consultants that owned homes in the county. The sample, which was limited to single-family homes spanned a period 
of two years (2000-2001), were matched by location, and consisted of 503 total property observations.

The authors found that on average, property tax consultants had a lower assessed value, regardless of whether the property value was determined via the Bexar County Assessor's Office or the Appraisal Review Board. While the authors found that Bexar County property tax consultants undertook more than 2.5 times as many appeals to the Appraisal Review Board than other homeowners, the authors were unable to determine whether an appraisal was reduced through an appeal.

Another scholar, interested in the potential challenges associated with a land value tax system (a property tax system, in which only the land taxed), examined the association of a property's land value ratio (assessed land value/total assessed market value) with the probability and outcome of an owner protesting the property's assessed value, and the resulting effects of property tax protests on the uniformity of assessed property values (Plummer, 2010).

Specifically, Plummer’s study addressed three questions:

- Was a property's land value ratio associated with the likelihood that a property owner would protest the property's assessed market value?

- If a protest was filed, was a property's land value ratio associated with the percentage decrease in the property's assessed market value that the owner realizes through the appeals process?

- Was the assessment uniformity of total property value affected by adjustments made in the appeals process? More specifically, was the assessment uniformity of land value and improvement value affected by adjustments made in the appeals process?

Plummer sampled all single-family residential properties in Harris County (Houston) Texas from 2006 through 2008. The study utilized available data from the 
Harris County Appraisal District Real Property Database and from the Harris County Appraisal District's Protest and Hearing files. The sample consisted of between 832,628 to 891,032 single-family properties in each of the three years.

To address the aforementioned research questions and to account for a possible issue with endogeneity (same issue in Weber \& McMillen study), the author utilized Heckman's two-stage estimation process (Heckman, 1979). In the first stage, the author addressed question one by utilizing a probit model, separately each year, to explain an owner’s likelihood of protesting the property’s assessed market value.

$$
\text { Protest }_{i t}=\propto_{0}+\propto_{1} L V R_{i t-1}+\emptyset^{\prime Y_{i t}}+\varepsilon_{i t}
$$

Where, Protest served as a binomial variable equal to one if the owner protests the property valuation, and equal to zero otherwise. $L V R_{i t-1}$ represented property i's land value ratio for year $t-1$. If $\propto_{1}>0\left(\propto_{1}<0\right)$, this suggests that owners are more likely (less likely) to file a protest as their land value ratio increases. $Y_{i}$ was a vector of variables, which are likely to affect the likelihood that a property owner protests his property valuation.

The results of the probit model indicated that the author correctly classified the model. However, the coefficient for LVR changed across the years. The LVR coefficient was positive for 2006, negative for 2007, and positive but only marginal significant for 2008. The fluctuations with the coefficient suggest that LVR was not systematically associated with likelihood that a property owner will protest their value.

In the second stage, the author addressed the remaining two questions by utilizing a maximum likelihood estimation approach. Here, Plummer used the predicted probabilities from the probit model to construct an inverse Mills ratio $\left(\lambda_{\text {it }}\right)$, which was 
then included as an explanatory variable in the models to address questions two and three. In order to answer question two, the author developed the following model for each year using all single-family residential properties for which an informal or formal appeals approach was completed:

$\% \Delta M K T V_{\text {hearing }_{i t}}=\beta_{0}+\beta_{1} L V R_{i t-1}+\beta_{2}$ Formal $_{i t}+\beta_{3}$ Agent $_{i t}+\beta_{4}$ Formal $_{i t} *$ Agent $_{i t}+$ $\delta^{\prime} Z_{i t}+\lambda_{\mathrm{i} \cdot \mathrm{t}}+\varepsilon_{\mathrm{i}}$

Where, $\% \Delta M K T V_{\text {hearing }_{i t}}$ represented the percentage decrease in property i's market value resulting from the appeals hearing. Formal $_{i t}$ served as a binomial variable equal to one if the protest is settled through an informal appeals hearing and equal to zero if settled through an informal appeals hearing. Agent $_{i t}$ also represented a binomial variable equal to one if the appeals hearing were handled by an agent, and zero if handled by the owner. $Z_{i t}$ was a vector of variables, which were likely to affect the magnitude of an appeals adjustment. $\lambda_{\text {it }}$ was the selectivity term (inverse Mills ratio) for property $i$ in year $t$, computed from the probit model.

Based on the results of the $\% \Delta M K T V_{\text {hearing }}$ model, the author made the following conclusions: First, if an owner filed a protest, the percentage appeals adjustment decreased as a property's land value ratio increased. Second, the appeals adjustments of owners who represented themselves were about $1 \%$ greater if they settled their appeal through a formal hearing. Third, the appeals adjustments of owners whose protest was settled through an informal hearing are between $0.6 \%$ and $2.3 \%$ lower if the owner used an agent. Lastly, the appeals adjustments of owners whose protest was settled through a formal hearing were between $2.6 \%$ and $3.4 \%$ lower if owners used an agent compared with representing themselves. 
For the third question, which addressed assessment uniformity, the following models were developed:

$\log _{-}$InitialMKTV $i t$

$$
=\theta_{0}+\theta^{\prime X_{i t}}+\theta_{1} \text { Adjustment }_{i t}+\theta_{2} \text { NoAdjustment }_{i t}+\theta_{3} \lambda_{i t}+\propto_{i j t}+\varepsilon_{i t}
$$

Log_FinalMKTV $_{i t}=\theta_{0}+\theta^{\prime X_{i t}}+\theta_{1}$ Adjustment $_{i t}+\theta_{2}$ NoAdjustment $_{i t}+\theta_{3} \lambda_{i t}+\propto_{i j t}+\varepsilon_{i t}$

Where, $\log _{-}$InitialMKTV $V_{i t}$ was the log of total assessed market value for property i, before appeals adjustment (if any). $\log _{-}$FinalMKTV $V_{i t}$ was the log of total market value for property i, after appeals adjustment (if any). $\mathrm{X}_{\text {it }}$ represented a vector of property characteristics for property i. Adjustment ${ }_{i t}$ was a binomial variable equal to one if the property’s value was lowered through the appeals process, and zero if otherwise. NoAdjustment $t_{i t}$ was a binomial variable equal to one if the property’s value was not lowered through the appeals process and zero if otherwise. After controlling for other determinants of market value, the results suggest assessed market values for protest properties are greater than values for non-protest properties. The author interprets this as evidence that the appeals process increased assessment uniformity because the market values of appealed properties were reduced.

In 2012, Hissong and Hawley revisited the theme of whether the occurrence of property tax appeals were a precursor to a full tax revolt (Hissong \& Hawley, 2012). The authors examined market differences, housing types, and appraisal board outcomes between 2001 and 2009, to assess the degree to which market predictors contribute to differences in protest rates and outcomes in Tarrant County (Fort Worth) Texas. Specifically, Hissong and Hawley were interested in answering the following questions: 
- Is the percentage of property owners who protest on the rise?

- Have protest outcomes changed over time?

- Do market valuations influence the decision to pursue a formal protest?

As an exploratory exercise, the study did not examine a causal relationship among the variables. Instead, the study focused on descriptive variables to provide insight and understanding concerning the Tarrant County property tax appeal process.

The authors structured the Tarrant County appeal process into five stages. Stage 1 involves the initial protest by the property owner or by an agent. Interestingly, agents may file a protest without an owner's permission. However, once the case proceeds to stage two, an owner's written permission is required. Stage 2 is the continued pursuit of the protest and includes owners who filed on their own, by an agent, or who have given an agent to continue the protest. During stage 2, the agent or owner must meet with the Tarrant County Appraisal District; those who do not meet with the appraisal district are prevented from moving on to stage three. Stage 3 is comprised of protestors who make and keep their appointments. Stages 4 and 5 are subsets of stage 3 . Stage 4 includes owners who participate in the informal appeal process. If the appeal cannot be resolved, the protestors move on to Stage 5, which is the formal appeal with Tarrant County Appraisal Review Board.

By structuring the appeal process into five stages, the authors were able to track the mean market values for the protested properties. The authors found that a "W" pattern emerged, in which the mean market values were relatively high for stages 1,3 , and 5. The authors interpret this pattern as evidence that the agents and property owners may have had a financial incentive. Because of the limitations of the available data, the 
authors were not able to conduct a case-by-case analysis. Thus, the amount lowered could not be determined, leaving the level analysis limited to the ordinal level.

The authors found that agents “fish” for clients by filing unrequested appeals. The data reveals that the number of appeals has risen for the given years. However, the authors are unable to determine whether the increase in appeals stems from discontent with the property tax or reflects an uncertain economy. In addition, the data revealed that until 2008, protest outcomes remained consistent. Since 2008, protestors have filed more protests with a higher percentage of market values lowered by the Appraisal Review Board. Finally, the authors conclude that market value appears to influence both the initial decision to file a protest and the decision to continue it. However, the authors are cautious to deem market value as the determinant variable because the public's knowledge of increased generosity of the Appraisal Review Board, the number of cases filed on the behalf of properties valued under $\$ 1,000$, and the lack of a random sample of protesting and non-protesting properties.

All of the aforementioned studies contributed to property tax administration literature by providing detailed descriptive analyses of local property tax review and appeal systems. However, many of the studies were limited in their explanatory and predictive capabilities. The more recent studies introduced theoretical models related to taxpayers' motives for appeal and have utilized regression analyses to support their findings (Firoozi, Hollas, Rutherford \& Thomson, 2006; Weber \& McMillen, 2010; Plummer, 2014). However, the question of whether appeals influenced the overall assessment uniformity of the respective taxing jurisdiction has produced mixed results. 
In terms of methodologies and research designs, the studies revealed some similarities and differences. All of the studies were limited to the county level and all of the authors relied upon available data sets obtained from their respective local assessor's offices. The authors utilized various types of data sets including cross-sectional, panel, and time-series data. With the exception of the Radcliff and Pennick study, all of the empirical analyses were limited to single-family residences. Limiting the research to single-family residences made the comparison of assessments easier, as opposed to other property types, such as income-producing properties, which may be harder to compare because of various sizes, uses, and investment objectives.

A limitation associated with these studies involved the lack of a consistent indicator of assessment uniformity. In some instances, the authors determined that a total assessment reduction won through appeals or the percent reduced in assessments for a total group of properties was an indicator of uniformity (Ratcliff \& Pennick, 1983; Firoozi, Hollas, Rutherford \& Thomson, 2006; Plummer, 2014). Weber and McMillen compared the physical location of appealed properties with census block information to determine whether the properties were being treated uniformly (Weber \& McMillen, 2010). Only Downing and Blocksidge expressly utilized the coefficient of dispersion as an indicator of uniformity (Blocksidge \& Downing, 1989). However, the Downing and Blocksidge study was largely a descriptive exercise.

At first glance, the lack of a consistent indictor of assessment uniformity in these studies are perplexing considering the coefficient of dispersion and price-related differential are industry standards for estimating assessment equity (IAAO, 1999). However, the literature has revealed that that the traditional measures require an estimate 
of market value to measure assessment error. This means that the appealed property would have to have experienced a recent sale in order to be analyzed by these traditional measures of assessment uniformity.

The State of Florida's Appeal and Review System

Utilizing Pops’s typology, the State of Florida's assessment review and appeal system can be characterized as a decentralized system with political, judicial, and taxpayer participative propensities (Pops, 1985). In the State of Florida, the assessment appeal mechanism is a decentralized institution administered at the county level. This assessment appeal mechanism is known as the Value Adjustment Board (VAB). Each VAB is comprised of a panel of appointed citizens and elected politicians. Specifically, the $\mathrm{VAB}$ consists of two members of the governing body of the county, one member of the school board, and two citizen members (Fl. Adm. Code. ch 12D, § 9.004. November, 2012). The VAB meets for the purposes of hearing petitions related to assessments, hearing complaints related to homestead exemptions, and hearing appeals concerning ad valorem tax deferrals and classifications (Fl. Adm. Code. ch 12D, § 9.005. November, 2012). The entity responsible for the day-to-day operations of the VAB is the clerk of each county’s governing body.

Typically, counties with a population greater than 75,000 , annually employ private-sector appraisers, who act as special magistrates, to preside over tax appeal hearings. The special magistrates take testimony and make recommendations on petitions filed with the value adjustment board. All of the VAB hearings take on a judicial demeanor, in which aspects such as preserving the record, actual notice, and due process requirements take priority (Fl. Adm. Code. ch 12D, § 9.025. November 2012). 
In addition, the State of Florida actively encourages taxpayer participation by sharing information with taxpayers and keeping filing fees relatively low (\$15). The county property appraiser and property owner may appeal the decision of the Value Adjustment Board by filing a lawsuit with the state circuit court (Section 194.036, Florida Statutes).

This dissertation builds upon the works of Weber, McMillen, and Plummer by examining the assessment review and appeal activities related to single-family homes, in two Florida counties, over a three-year period. Specifically, the dissertation incorporates elements of Weber and McMillen's Decision to Appeal, Plummer’s Value Change and the traditional indicators of assessment uniformity to examine single-family property owners' decision to appeal, the probability of a successful appeal, and the appeals subsequent effect on assessment uniformity. It is postulated that the variable interactions within these models, will reveal patterns allowing future practitioners, researchers, and policymaker to identify who utilizes assessment review and appeal systems, determine the likelihood for success, and measure the systems impact on assessment uniformity. 


\section{CHAPTER IV}

\section{RESEARCH DESIGN AND METHODOLOGY}

\section{$\underline{\text { Structure and Overview }}$}

This section will present and discuss the research design and methodology. First, the section outlines the research questions, hypotheses, and theoretical models that are utilized in the study. Next, is a discussion of the research design and data collection

methods. In the final section, the statistical analysis techniques utilized in the study are introduced and discussed.

$\underline{\text { Problem Statement }}$

Given the anecdotal evidence of a rise in the number of participants in the assessment review and appeal process, and its subsequent effect on local property tax bases, some interesting research questions arise:

Question 1: Are there certain economic and demographic factors, which influence a property owner's decision to file an appeal?

Question 2: Are there construction, assessment, and/or market characteristics that influence a property owner's decision to appeal?

Question 3: How do construction, assessment, market factors, and professional representation influence the probability of a successful appeal?

Question 4: How do the patterns of use and success in the property tax appeal process affect the overall distribution of the tax burden?

$\underline{\text { Hypotheses }}$

From these research questions and previous empirical literature, the following hypotheses and theoretical models were developed: 
Hypothesis 1: On average, demographic, and socio-economic factors such as education, income and race increase the probability that a property owner will appeal their property assessment.

Hypothesis 2: On average, construction factors have an inverse relationship to the decision to appeal, while assessment and market factors have a direct relationship to the decision to appeal.

Hypothesis 3: On average, construction, assessment, market factors, and professional representation positively influence the probability that an appeal is successful.

Hypothesis 4: The pattern of use and success improves the overall distribution of the tax burden.

\section{Theoretical Models}

Based on previous research concerning property tax review and appeals systems and property tax assessment uniformity, two models have been developed for this study (Paglin \& Fogarty, 1972; Geraci \& Plourde, 1976; Kochin \& Parks, 1984; Giertz \& Chicoine, 1990; Cornia \& Walters, 2005; Eom, 2008; Weber \& McMillen, 2010; Plummer, 2010; Doerner, 2012). These models examine the decision to appeal and the percentage change in value of a successful appeal, as dependent variables. The independent or explanatory variables utilized in each model can be grouped into four broad categories; the property's structural characteristics, assessment characteristics associated with a given property, neighborhood market activity, and neighborhood economic/demographic characteristics (Weber \& McMillen, 2010). It is postulated that the variable interactions within these models, will reveal patterns allowing the researcher to identify who utilizes assessment review and appeal systems, the degree of success, and 
whether certain characteristics of the assessment review and appeal system will produce correct, fair, and equitable results.

Decision to Appeal = f(structural characteristics, assessment practices, market activity, economics, and demographics)

Effectively, the Decision to Appeal Model treats the decision to appeal as a dependent binary variable equal to 1 if the property value is appealed and equal to 0 if the property is not appealed. The independent variables are a vector of variables that reflect the characteristics of property owners within a given area, the structural characteristics of their respective properties, data related to the local real estate market, and local assessment practices. The Decision to Appeal Model is utilized in the analysis of the survey data and available data sets. The explanatory variables for the Decision to Appel Model have been operationalized into Table 3.

Table 3

Decision to Appeal Model Explanatory Variables and Expected Signs

\begin{tabular}{|c|c|c|}
\hline Variable Name & Expected Sign & Category \\
\hline Age of Building, study year & + & \multirow{2}{*}{$\begin{array}{l}\text { Structural } \\
\text { Characteristics }\end{array}$} \\
\hline Total Living Area, study year & + & \\
\hline Sales Per Tract, study year & - & \multirow{2}{*}{$\begin{array}{l}\text { Market } \\
\text { Activity }\end{array}$} \\
\hline Recent Sale of Property, prior two years & - & \\
\hline Market Value, study year & + & \multirow{4}{*}{$\begin{array}{l}\text { Assessment } \\
\text { Characteristics }\end{array}$} \\
\hline Exemptions, study year & - & \\
\hline Percent Change in Market Value, previous year & + & \\
\hline Group Number 5, study year & + & \\
\hline Median Income (census tract) & + & \multirow{6}{*}{$\begin{array}{l}\text { Neighborhood } \\
\text { Economic and } \\
\text { Demographic } \\
\text { Characteristics }\end{array}$} \\
\hline Median Home Value (census tract) & + & \\
\hline Percent Black (census tract) & - & \\
\hline Percent White (census tract) & + & \\
\hline Percent without HS degree (census tract) & - & \\
\hline Percent with at least Bachelor Degree (census tract) & + & \\
\hline
\end{tabular}


Structural characteristics have been included in the Decision to Appeal Model to account for possible issues with assessment errors on the part of the local property appraiser. For instance, previous property tax literature has documented the difficulty in assessing older and larger properties (Bowman \& Butcher, 1986; Allen \& Dare, 2002). In terms of property age, older properties may suffer from physical and/or functional obsolescence issues, of which the local property appraiser may not be aware, leading to an over assessment of the property. In addition, property appraisers may have difficulty in finding comparable sales for much older homes. In terms of property size, empirical evidence suggests that assessment error has direct relationship with the square footage of a property, the larger the property the greater chance for an error (Allen \& Dare, 2002).

Weber and McMillen determined that the number of sales within a given area is inversely correlated with a property owner's decision to appeal (Weber \& McMillen, 2010). That is, if property owners have a better understanding of the sales activity in the area, they are less likely to file an appeal. Thus it is expected, that appeals are more likely to occur in areas with less sales activity. Similarly, the same expectation is true concerning the qualified sales activity of the appealed properties themselves. Property owners of recently sold properties will have a better understanding of the true market value of their respective property based on their purchase price and will be less likely file an appeal.

Included in the assessment characteristic categories are the variables; market value, percentage change in market value, exemptions, and PTOP group number. As mentioned in the Chapter 2 discussion concerning equity and property taxation, a property owner's tax liability is a function of the property appraiser's determination of 
market value for a given property and a taxing jurisdiction’s applied millage rate. Thus, controlling for the millage rate, as the market value of a property increases, a property owner's tax liability also increases. Consequently, it is expected that the variables of initial market value and change in market value from the previous year will be positively correlated with a property owner's decision to appeal.

In response to the taxpayer discontent, the State of Florida has adopted several tax policy measures intended to limit rapid increases in property tax bills. One of these policies is the Save Our Homes Amendment. The Save Our Home Amendment (more commonly referred to as a homestead exemption) grants an exemption from a homesteaded property's market value ranging from $\$ 25,000$ to $\$ 50,000$ (Section 196.031(1)(a)(b), Florida Statutes). In addition, the Save Our Home Amendment limits the increase in a properties assessed value to three percent or the Consumer Price Index, whichever is lower. Homeowners have to apply and meet certain qualifications to obtain the Save Our Homes exemption. Because of the various benefits associated with the Save Our Homes Amendment, it is anticipated that a property owner will be less likely to participate in the appeals process, if an exemption is associated with their property.

Lastly, in terms of assessment characteristics, the PTOP group number has been included as an explanatory variable. As mentioned in the previous discussion concerning Uniformity in the State of Florida, the PTOP annually conducts a sales qualification study and reviews the tax roll of each county. During these studies, the PTOP creates a value group stratification system, comprised of four equal value groups, for its sampling purposes. All parcels comprising the first five of the stratum's just value are substratified into Group Five and removed from further consideration of the study. Because 
these properties are excluded from the PTOP's assessment uniformity examination, it is anticipated that these properties will be appealed at a greater rate than non-Group Five properties.

In addition to the structural, market, and assessment considerations, neighborhood economic and demographic variables have been included in the Decision to Appeal Model. Economic and demographic data specific to a respective property owner is not collected by the property appraiser or the value adjustment board. However, a respective property's census tract number is included in the Florida Department of Revenue's data sets. Thus, census tract data such as race, education, and income may serve as proxies for the characteristics of these property owners ${ }^{4}$. These demographic factors may influence the decision to appeal a property value.

Previous studies have found that appeals application were more prevalent in census tracts with higher median incomes, median home values, and shares of college educated residents (Weber \& McMillen 2006; Doerner, 2012). In addition, appeals were less likely to be filed in majority Hispanic or Black areas (Weber \& McMillen 2006; Doerner, 2012). Based upon the previous research results, it is expected that appeals will less likely occur in census tracts with high concentrations of minorities.

Change in Market Value $=f($ property characteristics, assessment practices, market activity, professional representation, גit)

In addition to the decision to appeal, the change in the market value of appealed parcels is explored. As previously discussed, earlier studies have primarily examined the

\footnotetext{
${ }^{4}$ It is important to note that the demographic data discussed in this study refers to the census tract. Any other interpretation would be subject to an ecological fallacy, in which conclusions about individual property owners would be incorrectly based upon census tract data.
} 
output of the assessment review and appeals process in one of two ways. The first approach is to examine the probability of a successful appeal (Weber \& McMillen, 2010). Here, appeal success is framed as a binary output, in which a reduction in value is granted or denied. The second approach is to examine appeal success in terms of the change in market value for an appealed property (Plummer, 2010). Under this approach, the change is market value serves as a continuous dependent variable.

This study employed the change in market value model but utilized a slightly different approach in the development of the dependent variable. An examination of the available appeal data revealed the output of Florida's assessment review and appeals process can be characterized under several different categories: granted, denied, withdrawn, resolved, and no show. Granted indicates that the property appeal was heard and that a reduction in value was granted. Denied indicates the property appeal was heard that a reduction in value was not granted. These two categories were typically included in past studies of assessment review and appeal systems. Withdrawn indicated that the appeal was formally withdrawn for consideration by the VAB and the case was not formally heard. Resolved indicated that the hearing took place, but a reconciliation of value was reached between the property owner / agent and the property appraiser's office, without input from the special magistrate. A no show indicated that the case was heard at the VAB, but the property owner / agent failed to attend the hearing. The last three categories have not been included in previous studies.

In light of the various categories associated with the results of the VAB process, the Value Change Model includes any adjustment made to the just or market value of properties that were appealed. The intent is to account for properties that received 
reductions in market value, but were denied a reduction at the VAB or withdrawn from VAB consideration.

While the dependent variable differs slightly from the previous studies, in this instance, the independent variables are very similar. Independent variables will again include structural characteristics, assessment considerations, real estate market data, and economic/demographic characteristics. Unlike the Decision to Appeal Model, the Change in Market Value Model introduces new variables for consideration: quality of construction, professional representation and the inverse Mills ratio (to control for endogeneity).

In the Value Change Model, the probability of an appeal resulting in one of the four aforementioned categories is explored. The anticipated variable interactions reflect the same expectations utilized in the Decision to Appeal model. The Weber and McMillen study excluded demographic data from their Likelihood of Success model to reflect the possibility that property owners utilize a different calculus in deciding to appeal a particular property than the VAB uses in deciding to reduce a property's value (Weber \& McMillen, 2010). However, the importance in understanding the appeal's process impact on predominately minority neighborhoods should be included in the discussion, thus these variables are included in the appeal success model.

In addition to the age and size of a property, the quality of a single-family home may influence the likelihood of successful appeal. It is anticipated that properties with superior construction and made from higher grade materials may be more difficult to assess. This may contribute to an error on the local property appraiser's part, prompting a reduction in value. 
Table 4

Market Value Change Model Explanatory Variables and Expected Signs

\begin{tabular}{|c|c|c|}
\hline Variable Name & Expected Sign & Category \\
\hline Age of Building, study year & + & \multirow{3}{*}{$\begin{array}{l}\text { Structural } \\
\text { Characteristics }\end{array}$} \\
\hline Improvement Quality, study year & + & \\
\hline Total Living Area, study year & + & \\
\hline Sales Per Tract, study year & - & \multirow{2}{*}{$\begin{array}{l}\text { Market } \\
\text { Activity }\end{array}$} \\
\hline Recent Sale of Property, prior two years & - & \\
\hline Market Value, study year & + & \multirow{4}{*}{$\begin{array}{l}\text { Assessment } \\
\text { Characteristics }\end{array}$} \\
\hline Exemptions, study year & - & \\
\hline Percent Change in Market Value, previous year & + & \\
\hline Group Number 5, study year & + & \\
\hline Median Income (census tract) & + & \multirow{6}{*}{$\begin{array}{l}\text { Neighborhood } \\
\text { Economic and } \\
\text { Demographic } \\
\text { Characteristics }\end{array}$} \\
\hline Median Home Value (census tract) & + & \\
\hline Percent Black (census tract) & - & \\
\hline Percent White (census tract) & + & \\
\hline Percent without HS degree (census tract) & - & \\
\hline $\begin{array}{l}\text { Percent with at least Bachelor Degree (census } \\
\text { tract) }\end{array}$ & + & \\
\hline Professional Representation & ? & \\
\hline$\lambda_{i t}$ & ? & \\
\hline
\end{tabular}

In addition to the structural, market, assessment and economic/demographic considerations a variable for professional representation has been included in the Market Value Change Model. The variable professional representation indicates whether the property was represented by an individual other than the property owner at a respective VAB hearing. To qualify as a professional representative the individual may be an attorney, accountant, or a real estate professional (salespersons, brokers, and appraisers). Previous research has indicated mixed-results concerning the use of professional representation. Weber \& McMillen found that properties represented by professionals were less likely to receive a reduction (Weber \& McMillen, 2010). Doerner found that the "use of a tax representative is associated with a higher winning percentage (Doerner, 
2012).” While, Plummer's study indicated that property owners fare better, on average when professional representation is not utilized (Plummer, 2010).

Because property owners actively choose whether they will participate in the assessment review and appeals process, the Change in Market Value Model is subject to self-selection bias. To control for the possibility that a property owner's choice to appeal is endogenous, the model utilizes Heckman's two-stage estimation process (Heckman, 1979). In the Decision to Appeal Model, the probability that a property will be appealed is estimated. The study uses these predicted probabilities to construct an inverse Mills ratio, which is then included as an explanatory variable in the Likelihood of Success and Uniformity Models. It is anticipated that this procedure will help to prevent falsely associating differences in property values with an appeal hearing (Plummer, 2010).

Finally, in addition to determining the variables that influenced property owners and the likelihood of a successful appeal, the study examined whether outcomes of the appeal process significantly altered the tax burden. Here, the objective is to determine whether the appeal process shifts the burden to lower-valued properties (fostering a regressive tax system), shifts the burden to higher-valued properties (fostering a progressive tax system) or whether there is not significant change in the tax burden (fostering a proportional tax system). In this instance, the traditional indicators of assessment uniformity, the level of assessment, coefficient of dispersion, and pricerelated differential (see Chapter Two) are calculated and examined to determine the effect of the appeals process on assessment uniformity. 


\section{$\underline{\text { Research Design and Analyses }}$}

The guiding objectives of this study are description, explanation, and prediction. Specifically, this study is an exploration of Florida’s assessment review and appeal system, which provides a detailed description of who participates and is successful in the assessment and review process, examines whether the assessment and review process outcomes are proportional, regressive, or progressive. In particular, the study examines the appeals activity of single-family property owners in two Florida counties, Broward and Duval, over a three-year period (2010-2012).

In order to meet these objectives, this study utilizes a mixed-methods research design, which includes the use of a custom-designed survey instrument and the quantitative analysis of available data sets. Specifically, the primary data sources for the analysis include single-family property owners, the Florida Department of Revenue, and the county clerk's office. Secondary data sources include county budget documents, the United States Census Bureau, and the International Association of Assessing Officers.

The guiding hypotheses are tested at various levels ranging from the aggregate to the singular. In terms of the survey, the primary unit of analysis is the aggregated findings of respondents from Broward, and Duval counties. The second unit of analysis is the aggregated findings at each of the county levels for comparison purposes. In terms of the analyses of the available data sets, the primary unit of analysis is the parcel level. However, the findings of each appealed parcel will be aggregated at the census tract and county levels, in order to identify patterns of use and success.

The State of Florida serves as a good candidate for this analysis because it utilizes a single level (county) of assessment review and appeal system as opposed to 
other states, which may employ multiple-level (municipal, county, and state) appeal mechanisms. Additionally, limiting the research to a single state will control for regional differences and different state laws pertaining to assessment practices.

\section{Custom-Designed Survey}

The single-family property owner survey was constructed after reviewing various survey instruments and conducting a review of select survey research design literature (Converse \& Presser, 1986; Fowler, 2013). The survey was designed to address the research questions concerning single-family property owners' participation in the assessment review and appeals system. The survey instrument included questions related to the respective property owner's education level, income, race, and age. In addition, the survey included questions about their property’s structural and assessment characteristics. The survey also included questions related to the property owner's opinions about local government services and their relation to property taxes.

After accounting for all single-family properties, in a given jurisdiction, a random number generator was utilized to select five-hundred potential survey respondents from each county’s 2012 tax roll. In September and October of 2013, an informational letter, a traditional paper and pencil survey, and a paid return envelope were prepared and mailed to 1,000 potential respondents (See Appendix). The surveys were mailed at this particular time to correspond with the Truth-In-Millage notices and final property tax bill that are mailed annually. The expectation was that potential respondents might be more motivated to respond to a survey concerning property taxes during the height of property tax season. A traditional paper and pencil survey was utilized, as opposed to an electronic medium, because of the nature of the research. The objective was to explicitly 
reach property owners, thus the use of a survey website or email list was not considered a viable data collection option. Once sufficient time had been allotted for the return of completed surveys, data was entered and analyzed using STATA®13.1.

\section{$\underline{\text { Available Data Sets }}$}

In addition to the survey instrument, a data set was created to address the various research questions. The dataset consists of four sections or broad categories of data, which were fashioned from four separate datasets; each county’s value adjustment board records, the Florida Department of Revenue’s preliminary and final tax rolls, and the US Census Bureau’s Planning Database with 2010 Census and 2009-2013 American Community Survey Data (See Appendix).

Borrowing from the Weber and McMillen study, appeals data was matched with tax roll and census data to create an "appeals data set” (Weber \& McMillen, 2010). The appeals dataset reflects the assessment review and appeals activity related to singlefamily homes in Broward and Duval counties, over a period of three years; spanning from 2010 through 2012. In addition to the appealed properties, a control group of nonappealed properties was created. Fifty-five thousand single-family parcels were randomly selected from each county's tax roll for the respective period (resulting in 330,000 parcels total). Similar to the appealed data, the non-appealed tax roll data was merged with census data to reveal certain tract-level demographic and socio-economic variables.

The first section is comprised of data related to single-family parcels for a particular tax year. This section of the data set is derived from files supplied by each county’s respective Value Adjustment Board and Florida Department of Revenue. The 
VAB hearing data identifies the petitioned single-family parcels, the owner, and/or representative of the parcels, various pre- and post-hearing values related to the parcels, and the findings of the each hearing. Each parcel is identified by a unique identifier known as a parcel identification number or portfolio number.

The second section is derived from the Florida Department of Revenue's preliminary tax roll for the respective tax year. Here, preliminary parcel level tax data is paired with the corresponding appealed or non-appealed parcels identified in the first section, using the parcel identification number. The second section provides information related to the Florida Department of Revenue's assessment uniformity procedures and data related to the county appraiser's assessment activities; which include various values related to the parcels, parcel construction data, sales activity, census tract designation, and applicable property tax exemptions.

The third section is derived from the Florida Department of Revenue's final tax roll for the respective tax year. Here, the final tax roll data is paired with the corresponding VAB petitions data and preliminary tax roll data to provide insight concerning the final valuations for a respective tax year. In particular, the final tax roll data reflects the total change in just value between the preliminary tax roll and the final tax roll and provides a reason for the change.

The final section is derived from the US Census Bureau's 2009-2013 American Community Survey Data. Here, census data related to race, income, and education at the tract level is matched with the corresponding parcel. It is important to note, that individual demographic data is not collected by the county property appraiser or the value 
adjustment board. Thus, the only demographic data available is at the tract level and does not apply to the individual parcel.

Based on the previous research, variables were selected from the combined data set and analyzed using the two theoretical models previously discussed in this chapter. These models included the use of the Firth logit (penalized maximum likelihood estimation), and Heckman's two-stage maximum likelihood regressions; which were analyzed using STATA ${ }^{\circledR} 13.1$. 


\section{CHAPTER V}

\section{COUNTY SYNOPSES AND SURVEY RESULTS}

\section{$\underline{\text { Structure and Overview }}$}

This section presents a synopsis of each county along with the results of the single-family property owner survey. The section begins with a brief synopsis of Broward and Duval counties, which includes a description of their resident populations and relevant government structures. Next, the details of the survey instrument and results are presented and discussed. Finally, the section concludes with a summary of the survey results.

\section{Broward County Synopsis}

Broward County is located in southeast Florida, along the Atlantic Ocean coastline. The county has a total area of 1,323 square miles, of which 1,210 square miles is land mass. Of the total land mass, 800 square miles are dedicated to conservation (Florida Everglades).

As of 2013, the U.S. Census Bureau estimated the total population to be 1,845,393; representing a population increase of approximately six percent from April 1, 2010 to July 1, 2013 (http://quickfacts.census.gov). Broward County’s population is projected to grow to 1,855,896 by 2020 (http://flhousingdata.shimberg.ufl.edu).

The summary demographic data concerning Broward County reveals a racially and ethnically diverse population with private industry being a primary economic driver. In terms of the racial and ethnic composition of Broward County’s resident population, 43.5\% identify as White Non-Hispanic, 25.8\% identify as Black Non-Hispanic, 25.3\% of identify as Hispanic or Latino, while $5.4 \%$ of residents identify as other. Approximately 
$63.5 \%$ of the population is of working age (18-64) with $14.3 \%$ of the population being 65 years or older. The Broward County workforce is primarily comprised of private-sector employees; 74\% private industry; 3\% government; and 22\% self-employed. As of March 2013, the Cost of Living index for Broward County was 111.4 (national average is 100).

In terms of political partisanship, the voter registration data for 2015 indicates that of the total registered voters 50.63\% identified as Democratic 50.63, 25.93\% as no political affiliation, and 21.81\% as Republican (http://dos.myflorida.com/elections/datastatistics/voter-registration-statistics/voter-registration-monthly-reports/voter-registrationcurrent-by-county/).

Broward County is comprised of 31 cities, towns, and villages. The county government reflects a commission/administrator system, in which, nine county commissioners (two of which serve as mayor, and vice mayor) appoint a county administrator who serves at the inclination of the county commission.

The Broward County Property Appraiser's Office is an elected state constitutional office. As such, the Broward County Property Appraiser answers directly to the electorate and receives budget approval from the Florida Department of Revenue. As of 2012, the Broward County Property Appraiser’s Office comprised 202 employees, whom were responsible for assessing 735,921 real estate parcels. Of the 735,921 real estate parcels located in Broward County, residential parcels (which included condominiums, two-four unit apartment buildings, and single-family residences) totaled 647,680; and accounted for eighty-eight percent of all real property types. The total market value of all real property for the 2012 tax year was $\$ 170,328,484,030$; with residential parcels comprising sixty-two percent of the real property tax base. In all, for the 2012 tax year, 
Broward County and its respective taxing authorities levied approximately $\$ 3,054,000,000$ in real property taxes (FDOR, Broward County Property Tax Overview 2012).

In Broward County, the Value Adjustment Board is a part of the Finance and Administrative Services Department. The Finance and Administrative Services Department serves as the internal support system for Broward County's service delivery network. The Finance and Administrative Services Department falls under the purview of the appointed county administrator. The Finance and Administrative Department dedicates ten full-time employees to the daily operation of its Value Adjustment Board. In accordance with Florida Statutes, the Value Adjustment Board's budget is derived from a two-fifths contribution from the Broward County School Board and a three-fifths contribution from the Broward County Commission (Section 194.015, Florida Statutes). Duval County Synopsis

Duval County is located in Northeast Florida, and similar to Broward County, is bordered by the Atlantic Ocean to the east. Duval County is comprised of 918 square miles, of which 762 square miles consists of land mass. As of 2013, U.S. Census Bureau estimated the total population at 887,322; representing a population increase of approximately three percent from April 1, 2010 to July 1, 2013

(http://quickfacts.census.gov). Duval County’s population is projected to reach 934,098 by 2020 (http://flhousingdata.shimberg.ufl.edu).

The summary demographic statistics for Duval County reveals a less diverse (when compared to Broward County) population with public sector jobs representing a greater portion of the county workforce. Duval County is primarily comprised of white 
residents; $56.6 \%$ identify as White, $28.9 \%$ identify as Black, $7.6 \%$ as Hispanic, and $4.1 \%$ identify as Asian. Duval County is home to numerous military installations; as a result, a significant portion of the workforce is considered government or public sector: Private 62\%, Government 20\%, Self-employed 17\%. As opposed to Broward County, the Cost of Living Index for Duval County is below the national average at 89.1.

The voter registration data for 2015 indicates: Democratic 41\%, Republican 36.7\%, and No Political Affiliation at 19\% (http://dos.myflorida.com/elections/datastatistics/voter-registration-statistics/voter-registration-monthly-reports/voter-registrationcurrent-by-county/).

Duval County is comprised of four cities and one town. The county government reflects a unique political/administrative structure; the consolidated model. In 1968, the City of Jacksonville consolidated government functions with Duval County. During this time, the cities of Neptune Beach, Atlantic Beach, Jacksonville Beach, and the Town of Baldwin voted not to join the consolidated government. Duval County utilizes a strongmayor form of government, in which the mayor serves as the chief executive officer, while 19 county commissioners (14 districts, 5 at-large) are responsible for legislative functions.

The Duval County Property Appraiser's Office is an elected position and consists of approximately 120 employees. The Duval County Property Appraiser's Office is divided into seven departments; residential, commercial, land records, personal records, field operations, administration, and records management. The Property Appraiser’s responsibilities are governed by Florida Statues and the Jacksonville Municipal Code. 
The Florida Department of Revenue is responsible for reviewing the Property Appraiser's assessment roll. However, unlike Broward County, the Duval County Property Appraiser’s budget is maintained and approved through Duval County's General Fund (http://www.coj.net/departments/finance/docs/budget/fy15-proposed-budget.aspx).

As of 2012, the Duval County Property Appraiser’s Office was responsible for assessing 350,637 real estate parcels. Residential parcels totaled 286,917 and accounted for eighty-two percent of the jurisdiction's real property types. The total just value of all real property for the 2012 tax year was $\$ 66,155,915,693$; with single-family parcels accounting for fifty-four percent of the real property tax base. In all, the total property taxes levied for the 2012 tax year in Duval County, were \$977,322,171 (FDOR, Duval County Property Tax Overview 2012).

Duval County's Value Adjustment Board is comprised of the statutorily required members with the day-to-day operations administered through the Regulatory Boards and Commissions Department. Duval County dedicates three employees to the daily operation of its Value Adjustment Board. Again, in accordance with Florida Statutes, the Value Adjustment Board's budget is derived from a two-fifths contribution from the Duval County School Board and a three-fifths contribution from the Duval County Commission (Section 194.015, Florida Statutes).

\section{$\underline{\text { Survey Instrument }}$}

The single-family property owner survey was constructed after reviewing various survey instruments and conducting a review of select survey research design literature (Converse \& Presser, 1986; Fowler, 2013). The survey was specifically designed to address the research questions concerning single-family property owners' participation in 
the assessment review and appeals system. Reflecting Weber and McMillen's Decision to Appeal Model, the survey questions were developed to elicit information related to a property’s structural characteristics, assessment activity, market activity, and demographic/economic data specific to a property owner (Weber \& McMillen, 2010). In addition, the survey included questions related to a property owner’s opinions concerning local government services and property taxes. The government service and property tax questions were included to explore the "tax revolt” queries examined in previous empirical studies (Ratcliff \& Pennick, 1983; Hissong \& Hawley, 2012).

The property owner opinion questions were developed on a five-point Likert scale, where stakeholders were asked to indicate whether they strongly disagree, disagree, neutral, agree, or strongly agree with a series of statements concerning county government and property tax activities. The goal was to determine whether a property owner's opinions about county government and property taxes were correlated with a property owner's decision to appeal a property tax assessment. The development of the survey instrument resulted in a four-page questionnaire, which totaled thirty-one questions. These questions resulted in a total of forty-seven potential variables per observation.

After accounting for all single-family properties (properties classified as a duplex, condominium, townhouse, etc. were excluded utilizing the state and county land use codes) in a given jurisdiction, a random number generator was utilized to select fivehundred potential survey respondents from each county’s 2012 tax roll. In September and October of 2013, an informational letter, a traditional-paper-and-pencil survey, and a paid return envelope were prepared and mailed to one-thousand potential respondents 
(See Appendix). A traditional-paper-and-pencil survey was utilized, as opposed to an electronic medium, because of the nature of the research. The objective was to explicitly reach owners of single-family properties, thus the use of a survey website or email list was not considered a viable data collection option.

The surveys were mailed at this particular time to correspond with the Truth-InMillage notices and final property tax bill that are mailed annually. The expectation was that potential respondents might be more motivated to respond to a survey concerning property taxes during the height of property tax season, resulting in a higher survey response rate.

Unfortunately, the expectation of a higher response rate did not materialize. The total number of survey responses from Broward and Duval counties was 116; resulting in a combined response rate of $11.6 \%$. Disaggregated to the county level, the Broward County surveys yielded 67 respondents (13.4\%), while the Duval County surveys bore a total of 49 respondents (9.8\%). Of the total number of respondents, only eight property owners indicated previous participation in the formal appeal process.

The low response rate effectively negated any confidence in drawing statistically significant conclusions concerning the survey data. However, information concerning property tax appeals participation and the property owner's opinions regarding their county government and property taxes are provided for contextual purposes.

\section{Broward County Survey Results}

Tables 5 through 11, address the survey questions related to Broward County single-family property owners' participation in the property tax assessment appeal process. Table 5 indicates that $21 \%$ of respondents have previously contacted the 
Broward County Property Appraiser's Office to question the value of their property. Of the fourteen property owners that indicated participation in the informal appeal process, three indicated an increase in the market value, three indicated a decrease in the market value, while six indicated no change in market value (Table 6).

Interestingly, only $41.8 \%$ of respondents were aware that they could appeal the value of their property on a yearly basis (Table 7), despite appeal information being included in the annual TRIM notices and posted on the Broward County Property Appraiser’s website.

Of the total respondents, only $7.6 \%$ had previously filed a petition with the Broward County Value Adjustment Board (Table 8). Two of the five property owners utilized a property tax agent at the Value Adjustment Board (Table 9).

Table 5

Broward County Survey Informal Appeal Request

Have you ever contacted your county's property appraiser/tax assessor to question the value of your property?

\begin{tabular}{|l|l|l|}
\hline & \multicolumn{1}{|c|}{ Response Percent } & \multicolumn{1}{c|}{ Response Count } \\
\hline Yes & $20.9 \%$ & 14 \\
\hline No & $79.1 \%$ & 53 \\
\hline & Answered question & 67 \\
\hline & Skipped question & 0 \\
\hline
\end{tabular}

Table 6

Broward County Survey Informal Appeal Request Result

If yes, what was the result of your discussion with the property appraiser/tax assessor?

\begin{tabular}{|l|l|l|}
\hline & Response Percent & Response Count \\
\hline Value was increased & $4.5 \%$ & 3 \\
\hline No change to value & $9.1 \%$ & 6 \\
\hline Value was decreased & $4.5 \%$ & 3 \\
\hline Does not apply & $81.8 \%$ & 54 \\
\hline & Answered question & 66 \\
\hline & Skipped question & 1 \\
\hline
\end{tabular}


Table 7

Broward County Survey VAB Awareness

\begin{tabular}{|l|l|l|}
\hline \multicolumn{2}{|l|}{ Are you aware the value of your property can be appealed on a yearly basis? } \\
\hline & Response Percent & Response Count \\
\hline Yes & $41.8 \%$ & 28 \\
\hline No & $58.2 \%$ & 39 \\
\hline & Answered question & 67 \\
\hline & Skipped question & 0 \\
\hline
\end{tabular}

Table 8

Broward County Survey VAB Filing

If yes, have you ever filed an appeal with the Value Adjustment Board?

\begin{tabular}{|l|l|l|}
\hline & Response Percent & Response Count \\
\hline Yes & $7.6 \%$ & 5 \\
\hline No & $92.4 \%$ & 61 \\
\hline & Answered question & 66 \\
\hline & Skipped question & 1 \\
\hline
\end{tabular}

Table 9

Broward County Survey Use of Professional Representation

If you did file an appeal, did you use a representative to appeal the property's value?

\begin{tabular}{|l|l|l|}
\hline & Response Percent & Response Count \\
\hline Yes & $3 \%$ & 2 \\
\hline No & $4.5 \%$ & 3 \\
\hline Does not apply & $92.5 \%$ & 62 \\
\hline & Answered question & 67 \\
\hline & Skipped question & 0 \\
\hline
\end{tabular}

Table 10

Broward County Survey VAB Reduction

If you have filed an appeal, was a reduction in value obtained?

\begin{tabular}{|l|l|l|}
\hline & Response Percent & Response Count \\
\hline Yes & $4.5 \%$ & 3 \\
\hline No & $3 \%$ & 2 \\
\hline Does not apply & $92.5 \%$ & 62 \\
\hline & Answered question & 67 \\
\hline & Skipped question & 0 \\
\hline
\end{tabular}


Included in the survey questionnaire was a question that specifically addressed a property owner's motivation for filing an appeal. The question included a variety of variables explored in previous research literature. Again, because of the low response rate not much data can be gleaned from the survey results (Table 11).

Table 11

\section{Broward County Survey VAB Motivation}

\begin{tabular}{|l|l|l|}
\hline \multicolumn{2}{|l|}{ If you have filed an appeal, what was your motivation to file? } \\
\hline & Response Percent & Response Count \\
\hline $\begin{array}{l}\text { An increase in property } \\
\text { value }\end{array}$ & $0 \%$ & 0 \\
\hline $\begin{array}{l}\text { An increase in the amount } \\
\text { of taxes due }\end{array}$ & $0 \%$ & 0 \\
\hline $\begin{array}{l}\text { Sales of properties in area } \\
\text { indicated a lower value }\end{array}$ & $3 \%$ & 2 \\
\hline $\begin{array}{l}\text { Error in property } \\
\text { appraiser's records (for } \\
\text { example, incorrect } \\
\text { measurement) }\end{array}$ & $1.5 \%$ & 1 \\
\hline $\begin{array}{l}\text { Property tax agent's } \\
\text { advertisement }\end{array}$ & $0 \%$ & 0 \\
\hline Media report & $0 \%$ & 0 \\
\hline Word of mouth & $0 \%$ & 0 \\
\hline Other (please specify) & $0 \%$ & 0 \\
\hline Does Not Apply & $95.5 \%$ & 63 \\
\hline & Answered question & 66 \\
\hline & Skipped question & 1 \\
\hline
\end{tabular}

In addition to questions related to the tax appeal process, inquiries about singlefamily property owners' attitudes about property taxes were included. Tables 12 through 17 present the responses to those questions. Property owners indicated that the property tax was a fair mechanism to collect revenues for local services (Table 13). However, the owners do not feel that the revenues are utilized in an efficient manner, or that higher taxes were correlated with better government services (Tables 12, 14). 
Table 12

Broward County Survey Efficient Use of Property Taxes

\begin{tabular}{|l|l|l|}
\hline \multicolumn{2}{|l|}{ Money collected from property taxes is used in an efficient manner. } \\
\hline & Response Percent & Response Count \\
\hline Strongly Disagree & $7.7 \%$ & 5 \\
\hline Disagree & $33.9 \%$ & 22 \\
\hline Neutral & $32.3 \%$ & 21 \\
\hline Agree & $24.6 \%$ & 16 \\
\hline Strongly Agree & $1.5 \%$ & 1 \\
\hline & Answered question & 65 \\
\hline & Skipped question & 2 \\
\hline
\end{tabular}

Table 13

Broward County Survey Fairness of Property Taxes

Property taxes are a fair way to raise money for local services.

\begin{tabular}{|l|l|l|}
\hline & Response Percent & Response Count \\
\hline Strongly Disagree & $7.7 \%$ & 5 \\
\hline Disagree & $18.5 \%$ & 12 \\
\hline Neutral & $18.5 \%$ & 12 \\
\hline Agree & $43.0 \%$ & 28 \\
\hline Strongly Agree & $12.3 \%$ & 8 \\
\hline & Answered question & 65 \\
\hline & Skipped question & 2 \\
\hline
\end{tabular}

Table 14

Broward County Survey Relationship of Property Taxes to Local Services

\begin{tabular}{|l|l|l|}
\hline Higher property taxes equal better local services. \\
\hline & Response Percent & Response Count \\
\hline Strongly Disagree & $15.2 \%$ & 10 \\
\hline Disagree & $42.4 \%$ & 28 \\
\hline Neutral & $22.7 \%$ & 15 \\
\hline Agree & $18.2 \%$ & 12 \\
\hline Strongly Agree & $1.5 \%$ & 1 \\
\hline & Answered question & 66 \\
\hline & Skipped question & 1 \\
\hline
\end{tabular}


Despite concerns with the administration of property tax revenues, $56.9 \%$ of respondents preferred the property tax, when compared to the prospects of a state income tax (Table 15). Furthermore, $46.4 \%$ of Broward County property owners indicated that their property taxes were fair when compared to their neighbors (Table 16).

Table 15

Broward County Survey Property Tax Compared to State Income Tax

\begin{tabular}{|l|l|l|}
\hline \multicolumn{3}{|l|}{ I prefer property taxes when compared to state income taxes. } \\
\hline & Response Percent & Response Count \\
\hline Strongly Disagree & $10.8 \%$ & 7 \\
\hline Disagree & $15.4 \%$ & 10 \\
\hline Neutral & $16.9 \%$ & 11 \\
\hline Agree & $33.8 \%$ & 22 \\
\hline Strongly Agree & $23.1 \%$ & 15 \\
\hline & Answered question & 65 \\
\hline & Skipped question & 2 \\
\hline
\end{tabular}

Table 16

Broward County Survey Property Tax Compared to Neighbors My property taxes are fair when compared to my neighbors.

\begin{tabular}{|l|l|l|}
\hline & Response Percent & Response Count \\
\hline Strongly Disagree & $4.7 \%$ & 3 \\
\hline Disagree & $17.2 \%$ & 11 \\
\hline Neutral & $31.2 \%$ & 20 \\
\hline Agree & $40.1 \%$ & 26 \\
\hline Strongly Agree & $6.3 \%$ & 4 \\
\hline & Answered question & 64 \\
\hline & Skipped question & 3 \\
\hline
\end{tabular}

When asked to rate their property taxes to other household budgetary concerns, $30.7 \%$ of respondents stated that property taxes represented their greatest concern. Only hurricane insurance represented a greater household concern for property owners at $53.2 \%$. 
Table 17

Broward County Survey Greatest Household Budget Concern

\begin{tabular}{|l|l|l|}
\hline Which of the following household budget items represents your greatest concern? \\
\hline & Response Percent & Response Count \\
\hline Flood Insurance & 0 & 0 \\
\hline Hurricane Insurance & $53.2 \%$ & 33 \\
\hline Property Taxes & $30.7 \%$ & 19 \\
\hline Federal Income Taxes & $16.1 \%$ & 10 \\
\hline & Answered question & 62 \\
\hline & Skipped question & 5 \\
\hline
\end{tabular}

Most of the questions concerning property owners’ opinions concerning county government services indicated that local property owners were largely dissatisfied with the level of government service. Table 18 indicates that $50.8 \%$ of respondents disagreed or strongly disagreed with the statement that county government operates in an efficient manner. While, Table 19 shows that $44.7 \%$ of property owners disagreed or strongly disagreed with the statement that county officials consider the needs of local property owners. When presented with the statement that, “county officials are not influenced by special interests,” $72.7 \%$ of respondents disagreed or strongly disagreed with the statement.

Table 18

Broward County Survey Opinion of County Government Efficiency

\begin{tabular}{|l|l|l|}
\hline \multicolumn{2}{|l|}{ County government operates in an efficient manner. } \\
\hline & Response Percent & Response Count \\
\hline Strongly Disagree & $14.3 \%$ & 9 \\
\hline Disagree & $36.5 \%$ & 23 \\
\hline Neutral & $34.9 \%$ & 22 \\
\hline Agree & $14.3 \%$ & 9 \\
\hline Strongly Agree & $0 \%$ & 0 \\
\hline & Answered Question & 63 \\
\hline & Skipped Question & 4 \\
\hline
\end{tabular}


Table 19

Broward County Survey Opinion of County Government Meeting Needs of Owners County officials consider the needs of the local property owner.

\begin{tabular}{|l|l|l|}
\hline & Response Percent & Response Count \\
\hline Strongly Disagree & $10.8 \%$ & 7 \\
\hline Disagree & $33.9 \%$ & 22 \\
\hline Neutral & $43.1 \%$ & 28 \\
\hline Agree & $10.8 \%$ & 7 \\
\hline Strongly Agree & $1.5 \%$ & 1 \\
\hline & Answered Question & 65 \\
\hline & Skipped Question & 2 \\
\hline
\end{tabular}

Table 20

Broward County Survey Opinion of County Officials Operating in Ethical Manner

County officials operate in an ethical manner.

\begin{tabular}{|l|l|l|}
\hline & Response Percent & Response Count \\
\hline Strongly Disagree & $13.9 \%$ & 9 \\
\hline Disagree & $26.1 \%$ & 17 \\
\hline Neutral & $44.6 \%$ & 29 \\
\hline Agree & $13.9 \%$ & 9 \\
\hline Strongly Agree & $1.5 \%$ & 1 \\
\hline & Answered Question & 65 \\
\hline & Skipped Question & 2 \\
\hline
\end{tabular}

Table 21

Broward County Survey Opinion of Special Interest Influence

\begin{tabular}{|l|l|l|}
\hline County officials are not influenced by special interests. \\
\hline & Response Percent & Response Count \\
\hline Strongly Disagree & $30.3 \%$ & 20 \\
\hline Disagree & $42.4 \%$ & 28 \\
\hline Neutral & $22.6 \%$ & 15 \\
\hline Agree & $3 \%$ & 2 \\
\hline Strongly Agree & $1.5 \%$ & 1 \\
\hline & Answered Question & 66 \\
\hline & Skipped Question & 1 \\
\hline
\end{tabular}


Table 22

Broward County Survey Opinion of Service Level

\begin{tabular}{|l|l|l|}
\hline \multicolumn{2}{|c|}{ I am presently satisfied with the level of service provided by my county government. } \\
\hline & Response Percent & Response Count \\
\hline Strongly Disagree & $7.7 \%$ & 5 \\
\hline Disagree & $27.7 \%$ & 18 \\
\hline Neutral & $40 \%$ & 26 \\
\hline Agree & $23.1 \%$ & 15 \\
\hline Strongly Agree & $1.5 \%$ & 1 \\
\hline & Answered Question & 65 \\
\hline & Skipped Question & 2 \\
\hline
\end{tabular}

$\underline{\text { Duval County Survey Results }}$

Tables 23 through 29, address the survey questions related to the Duval County property owners' knowledge of, and experience with, the assessment appeal process. Table 24 indicates that $26.7 \%$ of respondents have previously contacted the Duval County Property Appraiser's Office to question the value of their property. Of the fourteen property owners that indicated participation in the informal appeal process, two indicated an increase in the market value, six indicated a decrease in the market value, while four indicated no change in market value (Table 24).

$62.5 \%$ of Duval County respondents were aware that they could appeal the value of their property on a yearly basis (Table 25). Of the total respondents, only 4 or $8.3 \%$ had indicated previously filing a petition with the Duval County Value Adjustment Board (Table 26). Only one owner indicated the use of a property tax agent at a Value Adjustment Board proceeding (Table 27). 
Table 23

Duval County Survey Informal Appeal Request

Have you ever contacted your county's property appraiser/tax assessor to question the value of your property?

\begin{tabular}{|l|l|l|}
\hline & Response Percent & Response Count \\
\hline Yes & $26.7 \%$ & 12 \\
\hline No & $73.3 \%$ & 33 \\
\hline & Answered question & 45 \\
\hline & Skipped question & 4 \\
\hline
\end{tabular}

Table 24

Duval County Survey Informal Appeal Request Result

If yes, what was the result of your discussion with the property appraiser/tax assessor?

\begin{tabular}{|l|l|l|}
\hline & Response Percent & Response Count \\
\hline Value was increased & $4.5 \%$ & 2 \\
\hline No change to value & $8.9 \%$ & 4 \\
\hline Value was decreased & $13.3 \%$ & 6 \\
\hline Does not apply & $73.3 \%$ & 33 \\
\hline & Answered question & 45 \\
\hline & Skipped question & 4 \\
\hline
\end{tabular}

Table 25

Duval County Survey VAB Awareness

\begin{tabular}{|l|l|l|}
\hline \multicolumn{2}{|l|}{ Are you aware the value of your property can be appealed on a yearly basis? } \\
\hline & Response Percent & Response Count \\
\hline Yes & $62.5 \%$ & 30 \\
\hline No & $37.5 \%$ & 18 \\
\hline & Answered question & 48 \\
\hline & Skipped question & 1 \\
\hline
\end{tabular}

Table 26

Duval County Survey VAB Filing

If yes, have you ever filed an appeal with the Value Adjustment Board?

\begin{tabular}{|l|l|l|}
\hline & Response Percent & Response Count \\
\hline Yes & $8.3 \%$ & 4 \\
\hline No & $91.7 \%$ & 44 \\
\hline & Answered question & 48 \\
\hline & Skipped question & 1 \\
\hline
\end{tabular}


Table 27

Duval County Survey Use of Professional Representation

\begin{tabular}{|l|l|l|}
\hline \multicolumn{2}{|l|}{ If you did file an appeal, did you use a representative to appeal the property's value? } \\
\hline & Response Percent & Response Count \\
\hline Yes & $2 \%$ & 1 \\
\hline No & $8.3 \%$ & 4 \\
\hline Does not apply & $89.7 \%$ & 43 \\
\hline & Answered question & 48 \\
\hline & Skipped question & 1 \\
\hline
\end{tabular}

Table 28

Duval County Survey VAB Reduction

\begin{tabular}{|l|l|l|}
\hline \multicolumn{2}{|l|}{ If you have filed an appeal, was a reduction in value obtained? } \\
\hline & Response Percent & Response Count \\
\hline Yes & $6.3 \%$ & 3 \\
\hline No & $4.2 \%$ & 2 \\
\hline Does not apply & $89.7 \%$ & 43 \\
\hline & Answered question & 48 \\
\hline & Skipped question & 1 \\
\hline
\end{tabular}

Table 29

\section{Duval County Survey VAB Motivation}

If you have filed an appeal, what was your motivation to file?

\begin{tabular}{|l|l|l|}
\hline & Response Percent & Response Count \\
\hline An increase in property value & $2.1 \%$ & 1 \\
\hline $\begin{array}{l}\text { An increase in the amount of } \\
\text { taxes due }\end{array}$ & $0 \%$ & 0 \\
\hline $\begin{array}{l}\text { Sales of properties in area } \\
\text { indicated a lower value }\end{array}$ & $6.4 \%$ & 3 \\
\hline $\begin{array}{l}\text { Error in property appraiser's } \\
\text { records (for example, incorrect } \\
\text { measurement) }\end{array}$ & $0 \%$ & 0 \\
\hline $\begin{array}{l}\text { Property tax agent's } \\
\text { advertisement }\end{array}$ & $0 \%$ & 0 \\
\hline Media report & $0 \%$ & 0 \\
\hline Word of mouth & $0 \%$ & 0 \\
\hline Other (please specify) & $2.1 \%$ & 1 \\
\hline Does Not Apply & $89.4 \%$ & 42 \\
\hline & Answered question & 47 \\
\hline & Skipped question & 2 \\
\hline
\end{tabular}


In addition to questions related to the tax appeal process, inquiries concerning property owners' attitudes about property taxes were included. Tables 31 through 36 present the responses to those questions within the context of Duval County single-family property owners. Again, property owners (59.6\%) indicated that the property tax was a fair mechanism to collect revenues for local services (Table 31), and that the revenues were not utilized in an efficient manner (Tables 30). Property owners disagreed or strongly disagreed that higher property taxes equate to better government services (Table 32).

\section{Table 30}

Duval County Survey Efficient Use of Property Taxes Money collected from property taxes is used in an efficient manner.

\begin{tabular}{|l|l|l|}
\hline & Response Percent & Response Count \\
\hline Strongly Disagree & $8.3 \%$ & 4 \\
\hline Disagree & $22.9 \%$ & 11 \\
\hline Neutral & $47.9 \%$ & 23 \\
\hline Agree & $14.6 \%$ & 7 \\
\hline Strongly Agree & $6.3 \%$ & 3 \\
\hline & Answered question & 48 \\
\hline & Skipped question & 1 \\
\hline
\end{tabular}

Table 31

Duval County Survey Fairness of Property Tax

\begin{tabular}{|l|l|l|}
\hline \multicolumn{2}{|l|}{ Property taxes are a fair way to raise money for local services. } \\
\hline & Response Percent & Response Count \\
\hline Strongly Disagree & $8.5 \%$ & 4 \\
\hline Disagree & $14.9 \%$ & 7 \\
\hline Neutral & $17.0 \%$ & 8 \\
\hline Agree & $44.7 \%$ & 21 \\
\hline Strongly Agree & $14.9 \%$ & 7 \\
\hline & Answered question & 47 \\
\hline & Skipped question & 2 \\
\hline
\end{tabular}


Table 32

Duval County Survey Relationship of Property Taxes to Local Services

\begin{tabular}{|l|l|l|}
\hline Higher property taxes equal better local services. \\
\hline & Response Percent & Response Count \\
\hline Strongly Disagree & $17.4 \%$ & 8 \\
\hline Disagree & $45.7 \%$ & 21 \\
\hline Neutral & $23.9 \%$ & 11 \\
\hline Agree & $10.8 \%$ & 5 \\
\hline Strongly Agree & $2.2 \%$ & 1 \\
\hline & Answered question & 46 \\
\hline & Skipped question & 3 \\
\hline
\end{tabular}

Despite concerns with the government services, $63.9 \%$ of respondents preferred the property tax, when compared to the prospects of a state income tax (Table 33). When asked to compare their property taxes to those of their neighbors only $6.4 \%$ of property owners did not feel their taxes were fair (Table 34).

Table 33

Duval County Survey Property Tax Compared to State Income Tax

\begin{tabular}{|l|l|l|}
\hline \multicolumn{2}{|l|}{ I prefer property taxes when compared to state income taxes } \\
\hline & Response Percent & Response Count \\
\hline Strongly Disagree & $2.1 \%$ & 1 \\
\hline Disagree & $2.1 \%$ & 1 \\
\hline Neutral & $31.9 \%$ & 15 \\
\hline Agree & $34.0 \%$ & 16 \\
\hline Strongly Agree & $29.9 \%$ & 14 \\
\hline & Answered question & 47 \\
\hline & Skipped question & 2 \\
\hline
\end{tabular}


Table 34

Duval County Survey Property Tax Compared to Neighbors

\begin{tabular}{|l|l|l|}
\hline My property taxes are fair when compared to my neighbors \\
\hline & Response Percent & Response Count \\
\hline Strongly Disagree & $2.1 \%$ & 1 \\
\hline Disagree & $4.3 \%$ & 2 \\
\hline Neutral & $46.8 \%$ & 22 \\
\hline Agree & $38.3 \%$ & 18 \\
\hline Strongly Agree & $8.5 \%$ & 4 \\
\hline & Answered question & 47 \\
\hline & Skipped question & 2 \\
\hline
\end{tabular}

When asked to rate their property taxes to other household budgetary concerns, 33.3\% of Duval County respondents stated that property taxes represented their greatest concern (Table 35). Only federal income taxes represented a greater household budget concern at $52.1 \%$.

Table 35

Duval County Survey Greatest Household Budget Concern

\begin{tabular}{|l|l|l|}
\hline Which of the following household budget items represents your greatest concern? \\
\hline & Response Percent & Response Count \\
\hline Flood Insurance & $6.3 \%$ & 3 \\
\hline Hurricane Insurance & $8.3 \%$ & 4 \\
\hline Property Taxes & $33.3 \%$ & 16 \\
\hline Federal Income Taxes & $52.1 \%$ & 25 \\
\hline & Answered question & 48 \\
\hline & Skipped question & 1 \\
\hline
\end{tabular}

Most of the questions concerning property owners' opinions about Duval County’s government services indicated that local property owners were largely dissatisfied with the level of service. Table 36 indicates that 36.7 of respondents disagreed or strongly disagreed with the statement that county government operates in an 
efficient manner. While just $12.2 \%$ of respondents agreed or strongly agreed with the same statement.

Table 37 shows that $36.7 \%$ of property owners disagreed or strongly disagreed with the statement that county officials consider the needs of local property owners. When presented with the statement that, “county officials are not influenced by special interests," $68.7 \%$ of respondents disagreed or strongly disagreed with the statement.

Table 36

Duval County Survey Opinion of County Government Efficiency County government operates in an efficient manner.

\begin{tabular}{|l|l|l|}
\hline & Response Percent & Response Count \\
\hline Strongly Disagree & $12.2 \%$ & 6 \\
\hline Disagree & $24.5 \%$ & 12 \\
\hline Neutral & $51.1 \%$ & 25 \\
\hline Agree & $10.2 \%$ & 5 \\
\hline Strongly Agree & $2 \%$ & 1 \\
\hline & Answered Question & 49 \\
\hline & Skipped Question & 0 \\
\hline
\end{tabular}

Table 37

Duval County Survey Opinion of County Government Meeting Needs of Owners County officials consider the needs of the local property owner.

\begin{tabular}{|l|l|l|}
\hline & Response Percent & Response Count \\
\hline Strongly Disagree & $14.3 \%$ & 7 \\
\hline Disagree & $20.4 \%$ & 10 \\
\hline Neutral & $46.9 \%$ & 23 \\
\hline Agree & $16.3 \%$ & 8 \\
\hline Strongly Agree & $2 \%$ & 1 \\
\hline & Answered Question & 49 \\
\hline & Skipped Question & 0 \\
\hline
\end{tabular}


Table 38

Duval County Survey Opinion of County Officials Operating in Ethical Manner

\begin{tabular}{|l|l|l|}
\hline County officials operate in an ethical manner. \\
\hline & Response Percent & Response Count \\
\hline Strongly Disagree & $10.2 \%$ & 5 \\
\hline Disagree & $14.3 \%$ & 7 \\
\hline Neutral & $61.2 \%$ & 30 \\
\hline Agree & $12.2 \%$ & 6 \\
\hline Strongly Agree & $2 \%$ & 1 \\
\hline & Answered Question & 49 \\
\hline & Skipped Question & 0 \\
\hline
\end{tabular}

Table 39

Duval County Survey Opinion of Special Interest Influence

County officials are not influenced by special interests.

\begin{tabular}{|l|l|l|}
\hline & Response Percent & Response Count \\
\hline Strongly Disagree & $25.0 \%$ & 12 \\
\hline Disagree & $43.7 \%$ & 21 \\
\hline Neutral & $20.8 \%$ & 10 \\
\hline Agree & $4.2 \%$ & 2 \\
\hline Strongly Agree & $6.3 \%$ & 3 \\
\hline & Answered Question & 48 \\
\hline & Skipped Question & 1 \\
\hline
\end{tabular}

Table 40

Duval County Survey Opinion of Service Level

\begin{tabular}{|l|l|l|}
\hline \multicolumn{2}{|l|}{ I am presently satisfied with the level of service provided by my county government. } \\
\hline & Response Percent & Response Count \\
\hline Strongly Disagree & $8.2 \%$ & 4 \\
\hline Disagree & $18.4 \%$ & 9 \\
\hline Neutral & $46.9 \%$ & 23 \\
\hline Agree & $26.5 \%$ & 13 \\
\hline Strongly Agree & $0 \%$ & 0 \\
\hline & Answered Question & 49 \\
\hline & Skipped Question & 0 \\
\hline
\end{tabular}




\section{Summary}

The survey represented an opportunity to glean data directly from the property owner; an aspect no other study concerning property tax assessment review and appeal systems has achieved. The expectation was to include an index of property owners' opinions with the structural, assessment, market, and demographic variables to explain and predict participation in the assessment review and appeal process. Unfortunately, the low response rates limited the use of the data; however, the survey was useful in providing descriptive data related to property owner's opinions concerning property taxes and government services.

The survey data revealed that approximately a quarter of the respondents had participated in the informal appeals process (contacting county property appraiser to make a value inquiry). Interestingly, some respondents had their property values increased as a result of the informal appeal process. The increase in market value is likely a product of Florida’s homestead exemption portability law ${ }^{5}$. A lower percentage of respondents reported moving beyond the informal process and actually filing a formal petition with Value Adjustment Board. Remarkably, 58.9\% of Broward respondents and 37.5\% of Duval respondents indicated they were unaware that their properties could be appealed on a yearly basis.

When questioned about attitudes concerning the property tax, the responses about the property tax itself were largely positive. Single-family property owners indicated that they preferred the property tax when compared to the prospect of a state income tax. In

\footnotetext{
${ }^{5}$ Section 193.155(8) of the Florida Statues allows a property owner with a previous Florida homestead exemption to transfer the difference between the market value and the assessed value to a new homesteaded property in Florida. As a result, property owners are now requesting an increase in their market value in order to obtain a greater tax savings for their new homesteaded property.
} 
addition, property owners felt their property taxes were fair when compared to their neighbors. However, the property owners did indicate that the property tax did represent a significant household budget concern in both counties. Albeit, each county did list a greater concern with Broward indicating hurricane insurance and Duval indicating federal income taxes as greater household concerns.

The survey data suggests that property owners in both counties were more disgruntled with the provision of government services and the conduct of government officials than the property tax itself. Respondents in both counties indicated that the revenues raised from property taxes were not utilized in an efficient manner, that government officials did not act in an ethical manner, and that government officials were influenced by special interests. 


\section{CHAPTER VI}

\section{BROWARD COUNTY APPEALS ANALYSES}

\section{$\underline{\text { Structure and Overview }}$}

This section presents the results of Broward County appeals analyses over the study period. The appeal activities of single-family property owners in Broward County were analyzed utilizing the Decision to Appeal and Value Change Models. The section then presents the traditional indicators of assessment uniformity, to determine whether the appeals activity of single-family property owners improved assessment uniformity in Broward County. The section concludes with a summary of the results. Broward County Decision To Appeal Model

This section examines the appeals activity of single-family property owners in Broward County from 2010 to 2012. During the period, the Broward County Value Adjustment Board received a total of 72,913 value change petitions, of these petitions 11,399 or $15.6 \%$ were classified as single-family properties (See Table 41).

Table 41

Broward County VAB Petitions for a Reduction in Value 2010-2012

\begin{tabular}{|l|r|r|r|r|r|r|}
\hline \multirow{2}{*}{ Broward County } & \multicolumn{2}{c|}{2010} & \multicolumn{2}{c|}{2011} & \multicolumn{2}{c|}{2012} \\
\cline { 2 - 7 } & \multicolumn{1}{|c|}{ Total } & Percent & Total & Percent & Total & Percent \\
\hline All appealed parcels & 26,273 & $100 \%$ & 24,748 & $100 \%$ & 21,892 & $100 \%$ \\
\hline Appealed single-family parcels & 4,068 & $15.4 \%$ & 3,813 & $15.7 \%$ & 3,518 & $16 \%$ \\
\hline
\end{tabular}

Based upon the descriptive statistics listed in Table 42, it appears that appeals were more prevalent in census tracts with higher median home values, higher median incomes, and a larger percentage of college graduates. Census tracts with a larger share of black residents were less likely to file an appeal as compared to the tracts with a larger 
share of white residents. Owners of more recently constructed, larger, and highly valued homes were more likely to utilize the assessment review and appeal system.

In 2010, both the appealed and non-appealed single-family parcels, were on average, assessed at a lower market value than the previous tax year. However, the nonappealed parcels indicated a larger reduction in the preliminary market value year-overyear. The 2011 data indicated an increase in the preliminary market value for nonappealed parcels, while the appealed parcels indicated a slight reduction in the preliminary market value. In 2012, the non-appealed preliminary market values were flat as compared to the previous tax year, whereas, the appealed parcels experienced a slight decrease in the preliminary market value. The sales per census tract were lower for the appealed parcels in 2010, however the opposite held true for the 2011 and 2012 tax years.

Previous literature indicates that the assumptions of parametric tests are not tenable for this type of research design. As a result, the Wilcoxon rank sum test is used to compare whether the independent variables are significantly different for the appealed versus non-appealed group for each year. Table 42 (Z-Score) suggests that the variables are significantly different on every variable except, Group Five of the 2010 tax year.

The maps of Broward County single-family parcels appealed by census tract (Figures 4, 5, 6) reveal that appealed parcels were largely clustered around the western suburban areas (including municipalities such as Parkland, Weston, and Miramar) and the eastern portions (Fort Lauderdale, Lauderdale by the Seas, and portions of the intracoastal waterway) of the county. While the total number of single-family parcel appeals declined over the study period (Table 41), the concentration of the appealed properties appeared to remain in the same areas of the county (Figures 4, 5, 6). 
Table 42

Descriptive Statistics for the Broward County Decision to Appeal Model

\begin{tabular}{|c|c|c|c|c|c|c|c|c|c|c|c|c|c|c|c|}
\hline \multirow{3}{*}{\begin{tabular}{|l} 
Independent Variables \\
\end{tabular}} & \multicolumn{5}{|c|}{2010} & \multicolumn{4}{|c|}{2011} & & \multicolumn{4}{|c|}{2012} & \\
\hline & \multicolumn{2}{|c|}{ Appealed } & \multicolumn{2}{|c|}{ Non-Appealed } & \multirow[b]{2}{*}{ Z-Score } & \multicolumn{2}{|c|}{ Appealed } & \multicolumn{2}{|c|}{ Non-Appealed } & \multirow[b]{2}{*}{ Z-Score } & \multicolumn{2}{|c|}{ Appealed } & \multicolumn{2}{|c|}{ Non-Appealed } & \multirow[b]{2}{*}{ Z-Score } \\
\hline & Mean & $\begin{array}{l}\text { Std. } \\
\text { Dev. }\end{array}$ & Mean & $\begin{array}{l}\text { Std. } \\
\text { Dev. }\end{array}$ & & Mean & $\begin{array}{l}\text { Std. } \\
\text { Dev. }\end{array}$ & Mean & $\begin{array}{l}\text { Std. } \\
\text { Dev. }\end{array}$ & & Mean & $\begin{array}{l}\text { Std. } \\
\text { Dev. }\end{array}$ & Mean & \begin{tabular}{|c|} 
Std. \\
Dev.
\end{tabular} & \\
\hline $\begin{array}{l}\text { LOG TOTAL LIVING } \\
\text { AREA }\end{array}$ & 7.816 & 0.619 & 7.542 & 0.404 & $-27.15 * * *$ & 7.908 & 0.599 & 7.525 & 0.404 & $-40.86 * * *$ & 7.846 & 0.575 & 7.532 & 0.404 & $-32.33 * * *$ \\
\hline AGE OF BUILDING & 28.007 & 21.184 & 29.797 & 16.458 & $10.13^{* * *}$ & 29.196 & 21.078 & 32.395 & 16.974 & $12.89 * * *$ & 30.002 & 20.142 & 33.299 & 16.963 & $12.36 * * *$ \\
\hline $\begin{array}{l}\text { RECENT SALE } \\
\text { DIRECTION }\end{array}$ & 0.190 & 0.547 & 0.116 & 0.457 & $-13.07 * * *$ & 0.154 & 0.493 & 0.112 & 0.448 & $-8.50 * * *$ & 0.140 & 0.486 & 0.1182 & 0.462 & $-4.15 * * *$ \\
\hline SALES PER TRACT & 115.571 & 99.022 & 122.295 & 91.265 & $12.16^{* * *}$ & 76.691 & 72.869 & 72.805 & 54.456 & $5.76 * * *$ & 74.275 & 63.717 & 72.916 & 55.642 & $3.62 * * *$ \\
\hline $\begin{array}{l}\text { LOG PRELIMINARY } \\
\text { JUST VALUE }\end{array}$ & 12.708 & 1.002 & 12.043 & 0.612 & $-43.13 * * *$ & 12.832 & 0.989 & 11.992 & 0.663 & $-54.71 * * *$ & 12.657 & 1.022 & 11.951 & 0.713 & $-41.34 * * *$ \\
\hline $\begin{array}{l}\text { \% CHANGE VALUE } \\
\text { PREVIOUS YEAR }\end{array}$ & -0.162 & 0.233 & -0.212 & 0.127 & $-18.12 * * *$ & -0.012 & 0.540 & 0.038 & 0.224 & $19.20^{* * *}$ & -0.011 & 0.054 & 0.000 & 0.000 & $50.34 * * *$ \\
\hline GROUP FIVE & 0.020 & 0.139 & 0.020 & 0.141 & 0.258 & 0.031 & 0.173 & 0.040 & 0.195 & $2.73 * * *$ & 0.031 & 0.173 & 0.059 & 0.235 & $6.89 * * *$ \\
\hline $\begin{array}{l}\text { PERCENT W/O HS } \\
\text { DEGREE }\end{array}$ & 0.103 & 0.089 & 0.111 & 0.081 & $12.07 * * *$ & 0.088 & 0.078 & 0.114 & 0.080 & $24.99 * * *$ & 0.091 & 0.075 & 0.114 & 0.080 & $19.73^{* * *}$ \\
\hline EXEMPT & 0.421 & 0.494 & 0.784 & 0.411 & $52.31 * * *$ & 0.488 & 0.500 & 0.765 & 0.424 & $38.06 * * *$ & 0.477 & 0.500 & 0.758 & 0.428 & $37.04 * * *$ \\
\hline $\begin{array}{l}\text { LOG MEDIAN HOME } \\
\text { VALUE PER TRACT }\end{array}$ & 12.452 & 0.593 & 12.217 & 0.528 & $-24.91 * * *$ & 12.543 & 0.568 & 12.192 & 0.530 & $-37.38 * * *$ & 12.460 & 0.573 & 12.191 & 0.533 & $-27.84 * * *$ \\
\hline $\begin{array}{l}\text { LOG MEDIAN INCOME } \\
\text { PER TRACT }\end{array}$ & 11.061 & 0.458 & 11.007 & 0.417 & $-7.33 * * *$ & 11.125 & 0.446 & 10.974 & 0.421 & $-20.32 * * *$ & 11.094 & 0.429 & 10.976 & 0.422 & $-15.70 * * *$ \\
\hline $\begin{array}{l}\text { PERCENT W/AT LEAST } \\
\text { BACHELOR }\end{array}$ & 0.373 & 0.172 & 0.323 & 0.154 & $-18.94 * * *$ & 0.402 & 0.164 & 0.315 & 0.153 & $-32.11 * * *$ & 0.384 & 0.162 & 0.315 & 0.152 & $-24.53 * * *$ \\
\hline $\begin{array}{l}\text { PERCENT OF TRACT } \\
\text { BLACK }\end{array}$ & 0.193 & 0.245 & 0.242 & 0.241 & $24.15^{* * *}$ & 0.157 & 0.219 & 0.246 & 0.244 & $33.19 * * *$ & 0.173 & 0.214 & 0.247 & 0.246 & $24.10 * * *$ \\
\hline $\begin{array}{l}\text { PERCENT OF TRACT } \\
\text { WHITE }\end{array}$ & 0.730 & 0.249 & 0.660 & 0.236 & $-25.78 * * *$ & 0.766 & 0.225 & 0.658 & 0.241 & $-33.98 * * *$ & 0.745 & 0.223 & 0.657 & 0.242 & $-24.99 * * *$ \\
\hline
\end{tabular}

$* *, * * *$ indicates statistical significance at $10 \%, 5 \%, 1 \%$ respectively, using a two-tailed test. 
Figure 4

Broward County 2010 Percent of Single Family Parcels Appealed by Census Tract

Legend

PERCENT_OF_TOTAL_APPEALS

$0.000000-0.001722$

$0.001723-0.004673$

$0.004674-0.010330$

$0.010331-0.020167$

$0.020168-0.037137$ 
Figure 5

Broward County 2011 Percent of Single Family Parcels Appealed by Census Tract

Legend

PERCENT_OF_TOTAL_APPEALS

$0.000000-0.001836$

$0.001837-0.005770$

$0.005771-0.011015$

$0.011016-0.020194$

$0.020195-0.034094$ 
Figure 6

Broward County 2012 Percent of Single Family Parcels Appealed by Census Tract

Legend

PERCENT_OF_TOTAL_APPEALS

$\square .000000-0.001990$

$0.001991-0.005117$

$0.005118-0.010233$

$0.010234-0.017339$

$0.017340-0.027572$ 


\section{Broward County Decision to Appeal Model Results}

The results from the Decision to Appeal Model are presented in Table 43. The table demonstrates the relationship between the independent variables and the probability of filing an appeal for each year of the study. During the course of the data analysis concerning the Decision to Appeal Model, an issue concerning the use of the traditional probit regression was encountered. For seemingly random years in both counties, the maximum likelihood algorithm utilized in the probit regression failed to converge.

After reexamining the data sets, introducing alternative regression models, and studying the statistical literature concerning the failure of a maximum likelihood regression to converge, it was determined that the number of appeals were too small when compared to the number of non-appealed properties. As a result, a maximum likelihood regression analysis known as the penalized maximum likelihood estimation or Firth Logit was adopted to analyze the Decision to Appeal data sets (Firth, 1993). The Firth Logit is a relatively new regression model utilized to explore rare event data in which the sample size is large $(n>200)$ and there are a large number of covariates.

The revised Decision to Appeal Model indicates that a number of the independent variables exhibited consistent relationships with the dependent variable throughout the study period. The coefficients on the preliminary just or market values were positive and statistically significant $(\mathrm{p}<0.001)$, indicating that more expensive properties were more likely to be appealed. The exemption variable was significantly negative for all years $(\mathrm{p}<0.001)$, indicating properties with homestead exemptions were less likely to be appealed then properties that did not have a homestead exemption. Group Five properties exhibited a positive and statistically significant $(\mathrm{p}<0.001)$ relationship with the decision 
to appeal, which indicates that properties excluded from the PTOP's sales analysis were more likely to appealed than properties that were included in the sales analysis. In addition, the variables indicating the percentage of residents without a high school education and the racial composition of a given census tract were all indicated a positive coefficient and were statistically significant $(\mathrm{p}<0.001)$.

Other variables indicated a consistent coefficient, but were inconsistent in terms of statistical significance over the study period; providing only limited evidence of their relationship to the decision to appeal. Building size indicated a negative coefficient for all years, which indicates that the probability that a property is appealed is smaller for larger properties. In addition, the building age indicated a negative coefficient for all three years, indicating that newer properties were more likely to be appealed. The sales per census tract variable for the Broward County data was relatively flat, with the coefficients hovering around zero for all three years. In addition, variables including the share of college graduates per census tract and the median income per census tract all indicated a negative coefficient. The coefficient estimates for the percentage change in the property appraiser’s market value, are not consistent across years.

The summary statistics of the Firth Logit Model are consistent over the study period. The Wald Chi-Square tests indicate scores of 5,242.78; 5,194.92; and 3,853.51, with a p-value of .0000 respectively. That is, if none of the independent variables has an impact on appealing a property, the probability of achieving the Wald Chi-Square scores would be less than .0001. Therefore, there is confidence in rejecting the null hypothesis and one can conclude that dependent variable, appealed, is related to at least one of the independent variables in the population. 
Table 43

Firth Logit Results for Broward County Decision to Appeal Model

\begin{tabular}{|c|c|c|c|c|c|c|c|c|c|}
\hline Broward County & \multicolumn{3}{|c|}{2010} & \multicolumn{3}{|c|}{2011} & \multicolumn{3}{|c|}{2012} \\
\hline Independent Variables & \begin{tabular}{c|} 
Estimated \\
Coefficient
\end{tabular} & $\mathrm{z}$ & $\mathrm{P}>\mathrm{Z}$ & $\begin{array}{l}\text { Estimated } \\
\text { Coefficient }\end{array}$ & $\mathrm{z}$ & $\mathrm{P}>\mathrm{Z}$ & $\begin{array}{c}\text { Estimated } \\
\text { Coefficient }\end{array}$ & $\mathrm{z}$ & $\mathrm{P}>\mathrm{Z}$ \\
\hline LOG TOTAL LIVING AREA & -0.553 & -6.810 & 0.000 & -0.071 & -0.850 & 0.396 & -0.027 & -0.300 & 0.761 \\
\hline AGE OF BUILDING & -0.007 & -5.330 & 0.000 & 0.000 & -0.350 & 0.728 & -0.003 & -2.470 & 0.014 \\
\hline RECENT SALE DIRECTION & 0.133 & 3.930 & 0.000 & -0.055 & -1.440 & 0.151 & -0.154 & -3.920 & 0.000 \\
\hline SALES PER TRACT & 0.000 & 1.730 & 0.084 & 0.001 & 2.970 & 0.003 & -0.001 & -1.450 & 0.147 \\
\hline LOG PRELIMINARY JUST VALUE & 1.941 & 33.570 & 0.000 & 1.835 & 31.710 & 0.000 & 1.395 & 23.720 & 0.000 \\
\hline \% CHANGE VALUE PREVIOUS YEAR & -0.062 & -0.440 & 0.658 & 0.049 & 0.890 & 0.371 & -41.477 & -13.410 & 0.000 \\
\hline GROUP FIVE & 0.986 & 7.490 & 0.000 & 1.395 & 12.290 & 0.000 & 0.625 & 5.420 & 0.000 \\
\hline PERCENT W/O HS DEGREE & 6.193 & 13.680 & 0.000 & 5.743 & 11.390 & 0.000 & 2.686 & 5.280 & 0.000 \\
\hline EXEMPT & -1.768 & -45.820 & 0.000 & -1.555 & -38.720 & 0.000 & -1.493 & -37.220 & 0.000 \\
\hline LOG MEDIAN HOME VALUE PER TRACT & 0.265 & 3.610 & 0.000 & 0.291 & 3.810 & 0.000 & 0.139 & 1.790 & 0.073 \\
\hline LOG MEDIAN INCOME PER TRACT & -0.276 & -2.930 & 0.003 & -0.155 & -1.600 & 0.109 & -0.144 & -1.450 & 0.148 \\
\hline PERCENT W/AT LEAST BACHELOR & -0.748 & -2.560 & 0.011 & -0.450 & -1.500 & 0.135 & -0.914 & -3.000 & 0.003 \\
\hline PERCENT OF TRACT BLACK & 3.240 & 7.830 & 0.000 & 2.984 & 6.710 & 0.000 & 1.771 & 4.020 & 0.000 \\
\hline PERCENT OF TRACT WHITE & 3.449 & 8.130 & 0.000 & 3.093 & 6.940 & 0.000 & 1.696 & 3.840 & 0.000 \\
\hline CONSTANT & -24.828 & -22.330 & 0.000 & -29.003 & -25.430 & 0.000 & -20.245 & -18.080 & 0.000 \\
\hline & Number of obs & & 58,731 & Number of obs & & 58,704 & Number of obs & & 58,647 \\
\hline & Wald chi2(14) & & 5242.78 & Wald chi2(14) & & 194.92 & Wald chi2(14) & & 853.51 \\
\hline & Prob $>$ chi2 & & 0.0000 & Prob > chi2 & & 0.0000 & Prob $>$ chi2 & & 0.0000 \\
\hline & $\begin{array}{l}\text { Penalized } \\
\text { Log-likelihood }\end{array}$ & -111 & 166.907 & $\begin{array}{l}\text { Penalized } \\
\text { Log-likelihood }\end{array}$ & -107 & 05.607 & $\begin{array}{l}\text { Penalized } \\
\text { Log-likelihood }\end{array}$ & -1063 & 31.473 \\
\hline
\end{tabular}




\section{Broward County Value Change Model}

Table 45 provides the descriptive statistics for the variables utilized in the Broward County Value Change Model. The Value Change Model utilizes the same variables introduced in the Decision to Appeal Model, with the addition of two new variables; quality of construction and agent.

The quality of construction serves as an ordinal variable in which the quality of construction associated with a single-family parcel is indicated. For Broward County, the single-family parcels labeled as above average or below average appeared with greater frequency for the appealed parcels when compared to the non-appealed parcels.

In addition to the variable quality of construction, the variable, agent is included in the Value Change Model. Agent serves as a dichotomous variable (yes or no), in which, the use of a professional representative is indicated. Because the non-appealed parcels are not appealed, they are by default, not represented by professional representatives. In the case of Broward County, the descriptive statistics indicate an increase in the percentage of parcels represented by professional agents during the study period.

Table 44

Broward County Property Owners Utilizing a Professional Representative 2010-2012

\begin{tabular}{|l|r|r|r|r|r|r|}
\hline \multirow{2}{*}{$\begin{array}{c}\text { Professional } \\
\text { Representation }\end{array}$} & \multicolumn{2}{|c|}{2010} & \multicolumn{2}{c|}{2011} & \multicolumn{2}{c|}{2012} \\
\cline { 2 - 7 } & Frequency & Percentage & Frequency & Percentage & Frequency & Percentage \\
\hline No & 1,458 & $35.84 \%$ & 609 & $15.97 \%$ & 380 & $10.80 \%$ \\
\hline Yes & 2,610 & $64.16 \%$ & 3,204 & $84.03 \%$ & 3,138 & $89.20 \%$ \\
\hline Total & 4,068 & $100.00 \%$ & 3,863 & $100.00 \%$ & 3,518 & $100.00 \%$ \\
\hline
\end{tabular}


While the Value Change Model utilizes the same variables as the Decision to Appeal Model, the descriptive statistics related to these variables are distinctly different. This difference is attributable to the examination of different dependent variables in each model and subsequently different means of comparison. In the Decision to Appeal Model, property owners' decisions to appeal were compared to property owners that did not appeal their respective properties. Conversely, in the Value Change Model, the change in market value for appealed properties is examined.

The descriptive statistics for the Broward County Value Change Model varied in relationship from year-to-year. Only the percent change in value from the previous year and the group five properties exhibited consistent patterns during this period. Appealed properties, which received a reduction, exhibited a reduction in market value by the property appraiser's office year-over-year. The mean for group five properties was lower in properties that received a reduction for the three-year period. The remainder of the variables all exhibited a different relationship among the means for the study period.

The previous maps of Broward County Single-Family Parcels Appealed by Census Tract (Figures 4, 5, 6) revealed that appealed parcels were largely clustered around the suburban (including municipalities such as Parkland, Weston, and Miramar) and the eastern portions (Fort Lauderdale, Lauderdale by the Seas) of the county. Interestingly, the following maps (Figures 7, 8, 9), which depict the percentage of parcels receiving a reduction within each census tract; indicate that a greater percentage of reductions were achieved in the interior portions of the county. The trend of interior parcels achieving a greater percentage of reduction is relatively consistent throughout the study period for Broward County. 
Table 45

Descriptive Statistics for Broward County Value Change Model

\begin{tabular}{|c|c|c|c|c|c|c|c|c|c|c|c|c|c|c|c|}
\hline \multirow{3}{*}{$\begin{array}{c}\text { Broward County } \\
\text { Independent Variables }\end{array}$} & \multicolumn{5}{|c|}{2010} & \multicolumn{5}{|c|}{2011} & \multicolumn{5}{|c|}{2012} \\
\hline & \multicolumn{2}{|c|}{ Reduction } & \multicolumn{2}{|c|}{ No Reduction } & \multirow[b]{2}{*}{ Z-Score } & \multicolumn{2}{|c|}{ Reduction } & \multicolumn{2}{|c|}{ No Reduction } & \multirow[b]{2}{*}{ Z-Score } & \multicolumn{2}{|c|}{ Reduction } & \multicolumn{2}{|c|}{ No Reduction } & \multirow[b]{2}{*}{ Z-Score } \\
\hline & Mean & $\begin{array}{l}\text { Std. } \\
\text { Dev. }\end{array}$ & Mean & $\begin{array}{l}\text { Std. } \\
\text { Dev. }\end{array}$ & & Mean & $\begin{array}{l}\text { Std. } \\
\text { Dev. }\end{array}$ & Mean & $\begin{array}{l}\text { Std. } \\
\text { Dev. }\end{array}$ & & Mean & $\begin{array}{l}\text { Std. } \\
\text { Dev. }\end{array}$ & Mean & $\begin{array}{l}\text { Std. } \\
\text { Dev. }\end{array}$ & \\
\hline $\begin{array}{l}\text { ABOVE AVERAGE } \\
\text { QUALITY }\end{array}$ & 0.403 & 0.011 & 0.429 & 0.010 & 1.55 & 0.496 & 0.025 & 0.408 & 0.008 & $-3.40 * * *$ & 0.404 & 0.029 & 0.400 & 0.009 & -0.09 \\
\hline AVERAGE QUALITY & 0.568 & 0.012 & 0.550 & 0.011 & -1.09 & 0.491 & 0.025 & 0.564 & 0.008 & $2.77 * * *$ & 0.568 & 0.029 & 0.579 & 0.009 & 0.38 \\
\hline $\begin{array}{l}\text { BELOW AVERAGE } \\
\text { QUALITY }\end{array}$ & 0.028 & 0.004 & 0.022 & 0.003 & -1.44 & 0.013 & 0.006 & 0.028 & 0.003 & $1.86^{*}$ & 0.028 & 0.010 & 0.021 & 0.002 & -0.86 \\
\hline LOG TOTAL LIVING & 7.715 & 0.015 & 7.898 & 0.012 & $10.14 * * *$ & 7.845 & 0.035 & 7.916 & 0.010 & $2.52 * *$ & 8.017 & 0.042 & 7.830 & 0.010 & $-4.30 * * *$ \\
\hline AGE OF BUILDING & 29.371 & 0.521 & 26.890 & 0.428 & $-1.92 *$ & 26.586 & 1.116 & 29.516 & 0.359 & $3.74 * * *$ & 31.347 & 1.284 & 29.904 & 0.353 & -0.87 \\
\hline RECENT SALE DIRE & 0.152 & .011 & .0221 & .013 & $1.81^{*}$ & 0.178 & 0.249 & 0.151 & 0.008 & $-1.96 * *$ & 0.182 & 0.031 & 0.137 & 0.009 & $-2.27 * *$ \\
\hline SALES PER TRACT & 111.571 & 2.204 & 118.978 & 2.178 & $2.01 * *$ & 92.426 & 4.719 & 74.888 & 1.196 & $-1.87 *$ & 85.646 & 4.282 & 73.325 & 1.106 & $-2.31 * *$ \\
\hline LOG PRELIM JV & 12.660 & 0.024 & 12.747 & 0.021 & $3.20 * * *$ & 12.794 & 0.056 & 12.836 & 0.017 & 1.06 & 13.119 & 0.065 & 12.614 & 0.018 & $-7.43 * * *$ \\
\hline $\begin{array}{l}\text { \% CHANGE VALUE } \\
\text { PREVIOUS YEAR }\end{array}$ & -0.171 & 0.004 & -0.155 & 0.006 & $3.00 * * *$ & -0.078 & 0.014 & -0.004 & 0.010 & $4.15^{* * *}$ & -0.147 & .007 & 0.001 & .0002 & $54.88 * * *$ \\
\hline GROUP FIVE & 0.018 & 0.003 & 0.022 & 0.003 & 0.89 & 0.013 & 0.006 & 0.033 & 0.003 & $2.22 * *$ & 0.004 & 0.004 & 0.034 & 0.003 & $2.79 * * *$ \\
\hline PERCENT W/O HS & 0.122 & 0.002 & 0.088 & 0.002 & $-10.80 * * *$ & 0.115 & 0.005 & 0.085 & 0.001 & $-4.98 * * *$ & 0.081 & 0.004 & 0.092 & 0.001 & $3.23 * * *$ \\
\hline EXEMPT & 0.375 & 0.011 & 0.458 & 0.011 & $5.36 * * *$ & 0.373 & 0.024 & 0.503 & 0.009 & $4.84^{* * *}$ & 0.498 & 0.030 & 0.476 & 0.009 & -0.76 \\
\hline $\begin{array}{l}\text { LOG MEDIAN HOME } \\
\text { VALUE PER TRACT }\end{array}$ & 12.386 & 0.014 & 12.505 & 0.012 & $6.42 * * *$ & 12.405 & 0.033 & 12.559 & 0.009 & $3.81 * * *$ & 12.585 & 0.032 & 12.448 & 0.010 & $-4.34 * * *$ \\
\hline $\begin{array}{l}\text { LOG MEDIAN } \\
\text { INCOME PER TRACT }\end{array}$ & 10.997 & 0.011 & 11.112 & 0.009 & $8.44 * * *$ & 11.031 & 0.027 & 11.135 & 0.007 & $4.40 * * *$ & 11.169 & 0.026 & 11.087 & 0.008 & $-3.21 * * *$ \\
\hline $\begin{array}{l}\text { PERCENT W/AT } \\
\text { LEAST BACHELOR }\end{array}$ & 0.346 & 0.004 & 0.396 & 0.003 & $9.01 * * *$ & 0.368 & 0.010 & 0.406 & 0.003 & $3.33 * * *$ & 0.424 & 0.010 & 0.380 & 0.004 & $-4.57 * * *$ \\
\hline PERCENT TRACT BK & 0.225 & 0.006 & 0.166 & 0.005 & $-7.04 * * *$ & 0.240 & 0.014 & 0.147 & 0.004 & $-5.63 * * *$ & 0.140 & 0.012 & 0.176 & 0.004 & $4.03 * * *$ \\
\hline PERCENT TRACT WT & 0.699 & 0.006 & 0.755 & 0.005 & $6.24 * * *$ & 0.682 & 0.014 & 0.776 & 0.004 & $5.69 * * *$ & 0.778 & 0.012 & 0.741 & 0.004 & $-3.25 * * *$ \\
\hline AGENT & 0.662 & 0.011 & 0.623 & 0.010 & $-2.55 * * *$ & 0.672 & 0.024 & 0.860 & 0.006 & $9.71 * * *$ & 0.642 & 0.028 & 0.914 & 0.005 & $14.18^{* * *}$ \\
\hline
\end{tabular}


Figure 7

Broward County 2010 Percent of Successful Single Family Parcel Appeals by Census Tract

Legend

PERCENT_REDUCED_WITHIN_TRACT

$\square .000000-0.125000$

$0.125001-0.363636$

$0.363637-0.555556$

$0.555557-0.800000$

$0.800001-1.000000$ 
Figure 8

Broward County 2011 Percent of Successful Single Family Parcel Appeals by Census Tract

\section{Legend}

PERCENT_REDUCED_WITHIN_TRACT

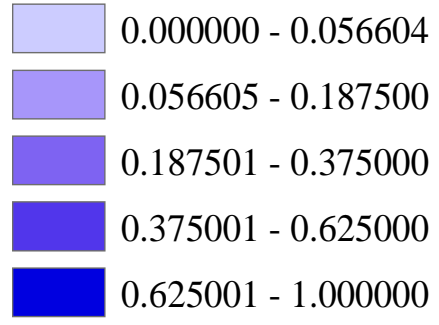


Figure 9

Broward County 2012 Percent of Successful Single Family Parcel Appeals by Census Tract

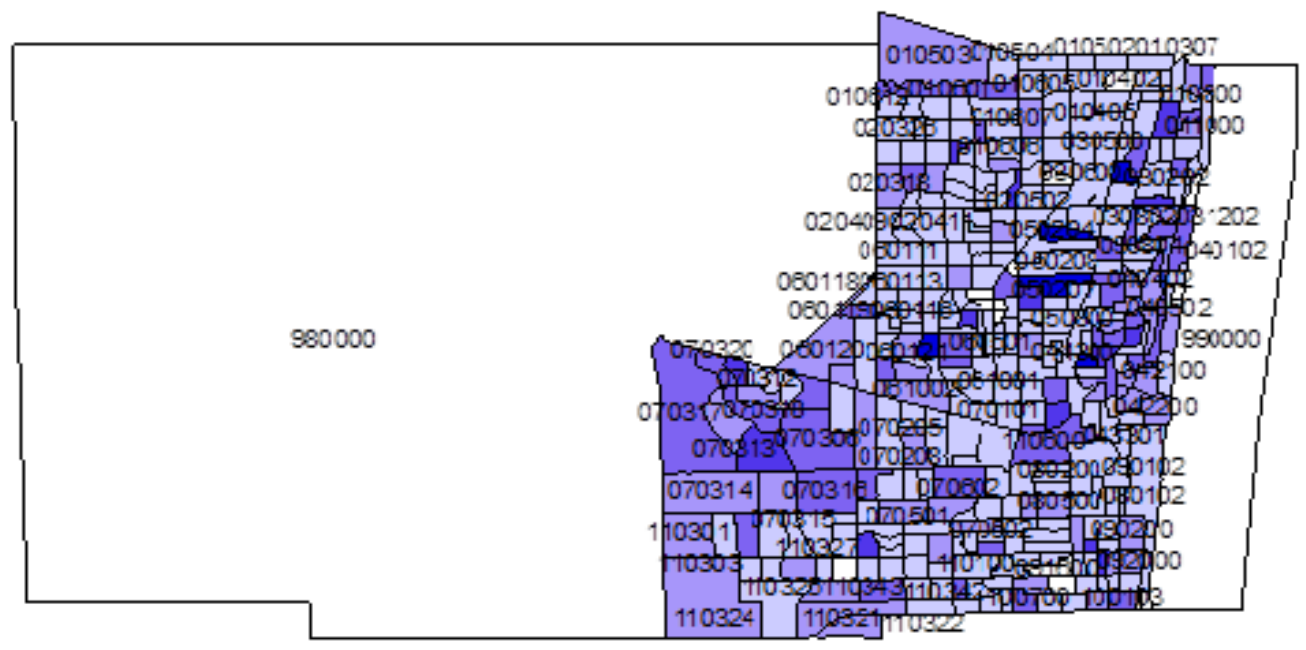

\section{Legend}

\section{PERCENT_REDUCED_WITHIN_TRACT}

\begin{tabular}{|c|}
\hline $0.000000-0.040816$ \\
\hline $0.040817-0.125000$ \\
\hline $0.125001-0.250000$ \\
\hline $0.250001-0.50000$ \\
\hline $500001-1$ \\
\hline
\end{tabular}




\section{Broward County Value Change Model Results}

Table 46 presents the maximum likelihood regression results for the Broward County Value Change Model. The model examines the effect the aforementioned independent variables have on the market value for appealed single-family properties.

The results of the value change analysis are largely mixed. Only one variable, the log of the preliminary just value, exhibited a consistent (positive) and statistically significant relationship $(\mathrm{p}<.001)$ over the three-year period. Many of the estimations were consistent for the 2010 and 2011 tax years, but the 2012 tax year often produced conflicting results. For example the total living area exhibited a negative coefficient and was statistically significant $(\mathrm{p}<0.001)$. However, the same variable exhibited a positive coefficient and was statistically insignificant for the 2012 tax year $(\mathrm{p}=.580)$. The log of the median income per census tract produced positive and statistically significant results for the $2010(\mathrm{p}<.001)$ and 2011 tax years $(\mathrm{p}<.05)$. For the 2012 tax year the result indicated a negative relationship that was not statistically significant $(\mathrm{p}=.536)$.

For the quality of construction, the below average category is omitted because of collinearity. For 2010, the remaining categories exhibit a negative coefficient. For the 2011, and 2012 tax years the above average and average coefficients are positive. These are variables are statistically insignificant for the entire period. The building age is negative for first two years, but positive for the 2012 tax year. Demographic variables produce conflicting results in terms of the coefficients and statistical significance throughout the study. The variable agent indicated that representation resulted in a larger decrease in the market value for 2010, but was less effective, as compared to owners that represented themselves, in obtaining a reduction for the 2011 and 2012 tax years. 
Table 46

Broward County MLE Regression Results for Percentage Change in Market Value

\begin{tabular}{|c|c|c|c|c|c|c|c|c|c|}
\hline Broward County Heckman Selection Model & \multicolumn{3}{|c|}{2010} & \multicolumn{3}{|c|}{2011} & \multicolumn{3}{|c|}{2012} \\
\hline Independent Variables & Est. Coefficient & $\mathrm{Z}$ & $\mathrm{P}>\mathrm{Z}$ & Est. Coefficient & $\mathrm{z}$ & $\mathrm{P}>\mathrm{Z}$ & Est. Coefficient & $\mathrm{z}$ & $\mathrm{P}>\mathrm{Z}$ \\
\hline ABOVE AVERAGE QUALITY & -0.075 & -0.44 & 0.662 & $\begin{array}{r}0.282 \\
\end{array}$ & 1.05 & 0.294 & 0.223 & 0.61 & 0.540 \\
\hline AVERAGE QUALITY & -0.021 & -0.15 & 0.881 & 0.330 & 1.39 & 0.164 & 0.337 & 1.06 & 0.290 \\
\hline BELOW AVERAGE QUALITY & 0 (omitted) & & & 0 (omitted) & & & 0 (omitted) & & \\
\hline LOG TOTAL LIVING AREA & -1.285 & -14.60 & 0.000 & -0.551 & -4.55 & 0.000 & 0.0869 & 0.55 & 0.580 \\
\hline AGE OF BUILDING & -0.003 & -1.52 & 0.128 & -0.007 & -2.85 & 0.004 & 0.007 & 1.97 & 0.049 \\
\hline RECENT SALE DIRECTION & -0.138 & -3.55 & 0.000 & 0.063 & 1.16 & 0.248 & 0.128 & 1.94 & 0.053 \\
\hline SALES PER TRACT & 0.001 & 4.35 & 0.000 & 0.003 & 6.66 & 0.000 & 0.001 & 1.18 & 0.240 \\
\hline LOG PRELIMINARY JUST VALUE & 0.879 & 14.50 & 0.000 & 0.520 & 6.56 & 0.000 & 0.241 & 2.39 & 0.017 \\
\hline$\%$ CHANGE VALUE PREVIOUS YEAR & -0.028 & -0.28 & 0.777 & -0.406 & -3.08 & 0.002 & -0.173 & -20.26 & 0.000 \\
\hline GROUP FIVE & -0.184 & -1.14 & 0.253 & 0.672 & 4.32 & 0.000 & -0.263 & -.0 .80 & 0.426 \\
\hline PERCENT W/O HS DEGREE & 3.834 & 7.12 & 0.000 & 4.105 & 5.11 & 0.000 & 0.723 & 0.67 & 0.505 \\
\hline EXEMPT & -0.045 & -1.03 & 0.303 & -0.223 & -3.37 & 0.001 & -0.037 & -0.47 & 0.642 \\
\hline LOG MEDIAN HOME VALUE PER TRACT & 0.002 & 0.03 & 0.979 & -0.514 & -4.66 & 0.000 & -0.235 & -1.58 & 0.113 \\
\hline LOG MEDIAN INCOME PER TRACT & 0.373 & 3.44 & 0.001 & 0.308 & 2.06 & 0.040 & -.0125 & -0.62 & 0.536 \\
\hline PERCENT W/AT LEAST BACHELOR & -1.224 & -3.65 & 0.000 & 0.577 & 1.23 & 0.219 & 1.126 & 1.79 & 0.074 \\
\hline PERCENT OF TRACT BLACK & -0.396 & -0.78 & 0.438 & 1.323 & 1.92 & 0.055 & -0.980 & -1.05 & 0.292 \\
\hline PERCENT OF TRACT WHITE & -0.471 & -0.90 & 0.366 & 1.114 & 1.57 & 0.117 & -1.432 & -1.54 & 0.124 \\
\hline AGENT & 0.153 & 3.37 & 0.001 & -0.515 & -7.26 & 0.000 & -0.578 & -5.76 & 0.000 \\
\hline CONSTANT & -4.986 & -3.99 & 0.000 & -2.097 & -1.18 & 0.238 & -0.442 & -0.19 & 0.847 \\
\hline \multicolumn{10}{|l|}{ mills } \\
\hline lambda & 0.145 & 4.51 & 0.0000 & 0.0128 & 2.82 & 0.005 & -.0004 & -0.32 & 0.752 \\
\hline \multicolumn{10}{|c|}{ note: BELOW AVERAGE QUALITY omitted because of collinearity } \\
\hline & Number of obs & & 3979 & Number of obs & \multicolumn{3}{|c|}{3804 Number of obs } & & 3504 \\
\hline & Censored obs & & 2169 & Censored obs & \multicolumn{3}{|c|}{ 3358Censored obs } & & 3167 \\
\hline & Uncensored obs & & 1810 & Uncensored obs & \multicolumn{3}{|c|}{ 445Uncensored obs } & & 337 \\
\hline & Wald chi2(14) & & 13310.130 & Wald chi2(14) & \multicolumn{3}{|c|}{ 111328.640Wald chi2(14) } & \multicolumn{2}{|c|}{798010.14} \\
\hline & \begin{tabular}{|l|l} 
Prob $>$ chi2 & \\
\end{tabular} & & 0.000 & Prob > chi2 & & 0.000 & Prob > chi2 & & 0.000 \\
\hline & \multicolumn{3}{|c|}{$\begin{array}{l}\text { note: two-step estimate of rho }=1.272 \text { is being } \\
\text { truncated to } 1\end{array}$} & \multicolumn{3}{|l|}{ rho $=.678$} & \multicolumn{3}{|l|}{ rho $=-.027$} \\
\hline
\end{tabular}




\section{Broward County Assessment Uniformity Results}

As previously discussed in Chapter Two, a distinctive characteristic of the property tax is that it is based upon an assessor's opinion of value, rather than being directly observed from market transactions (i.e., sales tax). The industry standard by which to judge the accuracy of assessment activities is to compare the assessments estimated by the property appraiser to the actual sales price of a given property. As a result, recent sales data serve as a critical element in evaluating the uniformity of property tax assessments.

In order to determine the effect of single-family appeals activity on the assessment uniformity of single-family properties located in Broward County, separate sales ratio studies were conducted for each year of the study period. Following the IAAO’s Standard on Ratio Studies and the State of Florida's administrative rules for property tax assessments, the ratio studies only included qualified sales, which occurred a year prior to the respective tax year's assessment date (January $1^{\text {st }}$ ). As a result of applying these criteria to the Broward County data, a total of 11,438 qualified sales were identified, of which 3,908 were from 2010, 3,754 from 2011, and 3,776 from 2012. Each of the identified sales was matched to their respective assessed value to create an assessment-to-sale ratio. Nonparametric procedures were then used to eliminate statistical outliers for each tax year (IAAO, 2010). The lower bound for trimming outliers was the $25^{\text {th }}$ percentile minus three times the interquartile range, and the upper bound was the $75^{\text {th }}$ percentile plus three times the interquartile range. Table 47 indicates the critical ratio values used for trimming the statistical outliers. The assessment-to-sale ratios were based on the preliminary assessed values and final assessed values for each 
tax year. Based on these critical values, any observation less than the lower bound, or greater than the upper bound, was eliminated from the ratio study analysis. Combined, the outlier trimming procedure removed 565 sales from the sample leaving 10,873 observations in Broward County assessment uniformity data set.

Table 47

Broward County VAB Ratio Study Outlier Trimming 2010-2012

\begin{tabular}{|l|c|c|c|c|c|c|}
\hline & \multicolumn{2}{|c|}{2010} & \multicolumn{2}{c|}{2011} & \multicolumn{2}{c|}{2012} \\
\cline { 2 - 7 } & $\begin{array}{c}\text { Assessment- } \\
\text { to-Sale } \\
\text { Ratio Based } \\
\text { on Initial } \\
\text { Assessed } \\
\text { Value }\end{array}$ & $\begin{array}{c}\text { Assessment- } \\
\text { to-Sale Ratio } \\
\text { Based on } \\
\text { Final } \\
\text { Assessed } \\
\text { Value }\end{array}$ & $\begin{array}{c}\text { Assessment- } \\
\text { to-Sale Ratio } \\
\text { Based on } \\
\text { Initial } \\
\text { Assessed } \\
\text { Value }\end{array}$ & $\begin{array}{c}\text { Assessment- } \\
\text { to-Sale Ratio } \\
\text { Based on } \\
\text { Final } \\
\text { Assessed } \\
\text { Value }\end{array}$ & $\begin{array}{c}\text { Assessment } \\
\text {-to-Sale } \\
\text { Ratio Based } \\
\text { on Initial } \\
\text { Assessed } \\
\text { Value }\end{array}$ & $\begin{array}{c}\text { Assessment- } \\
\text { to-Sale } \\
\text { Ratio Based } \\
\text { on Final } \\
\text { Assessed } \\
\text { Value }\end{array}$ \\
\hline 1st percentile & 0.624176 & 0.613465 & 0.645069 & 0.634444 & 0.565833 & 0.565833 \\
\hline 25th percentile & 0.849198 & 0.847194 & 0.852300 & 0.851743 & 0.857306 & 0.856969 \\
\hline Median & 0.878103 & 0.872800 & 0.889422 & 0.888430 & 0.908264 & 0.907597 \\
\hline 75th percentile & 0.959337 & 0.951647 & 0.971323 & 0.970945 & 0.969955 & 0.969398 \\
\hline 99th percentile & 1.708209 & 1.612000 & 2.316182 & 2.289533 & 1.476327 & 1.458250 \\
\hline $\begin{array}{l}\text { Lower bound } \\
\text { for trimming }\end{array}$ & 0.518781 & 0.533835 & 0.495233 & 0.494137 & 0.519360 & 0.519679 \\
\hline $\begin{array}{l}\text { Upper bound } \\
\text { for trimming }\end{array}$ & 1.289753 & 1.265006 & 1.328390 & 1.328550 & 1.307901 & 1.306687 \\
\hline
\end{tabular}

Five groups of assessment-to-sale ratio statistics were produced for the Broward County sample set. Each group reflects the traditional assessment uniformity metrics: mean, median, weighted mean, coefficient of dispersion, and the price related differential (see Chapter Two for further discussion).

The first group provided statistics for the preliminary tax roll. These statistics reflect the uniformity statistics of all sales observations prior to any review. The second group of statistics reflects the uniformity statistics of all observations after the assessment appeal and review process has been completed. In addition to the preliminary and final assessed value uniformity statistics, the data was further stratified to reflect non-appealed 
and appealed statistics. The third group reflects the uniformity statistics for which no appeal was filed. While the fourth and fifth groups identified the pre-appeal and postappeal ratio statistics for appealed properties.

Tables 48 through 50 provide the assessment-to-sale ratio statistics for the 2010, 2011, and 2012 tax years. For the 2010 tax year, the mean initial assessment-to-sale ratio for the preliminary tax roll is $89.3 \%$, while the median assessment-to-sale ratio is $87 \%$. The mean and median are $88.9 \%$ and $87 \%$ after the assessment review and appeal process. The non-appealed parcels reflect a similar mean and median of $88.6 \%$ and $87 \%$.

The statistics for the appeal preliminary category reveal that the mean assessmentto-sale ratio for the appealed properties was 93.3\%, while the median assessment-to-sale ratio was $89.9 \%$. In addition, the mean and median assessment-to-sale ratios for the appeal final group were $89.4 \%$ and $86.7 \%$, respectively. The mean and median assessment-to-sale ratio statistics were higher than the mean and median assessment-tosale ratio statistics for the non-appealed group. The comparison of the non-appealed ratios with the appealed preliminary ratios, for the 2010 tax year, suggests that appealed properties had higher preliminary assessments. Interestingly, the mean assessment-tosale ratio for final appealed properties (89.4\%) was higher than the mean assessment-tosale ratio for non-appealed properties (88.6\%). This pattern suggests that the appeal process lowered the assessments for properties that were initially too high, but perhaps the process did not lower the initial assessment enough (when compared to non-appealed parcels).

A comparison of the coefficient of dispersion for the five groups reveals that the assessment review and appeal process lowered the degree of variability in property tax 
assessments for the 2010 tax year; across all observations in the sample, the COD fell from 8.05 to 7.84 . When the sample was further divided into the non-appealed and appealed groups, a pronounced difference in the preliminary CODs is revealed; here, the preliminary non-appealed COD is 7.51, while the preliminary appealed COD is 10.07 . Once the appealed properties completed the assessment review and appeal process, the COD for appealed parcels declined from 10.07 to 8.63.

A comparison of the COD statistics reveals the same patterns as the comparison of the mean and median statistics. The appeal process lowered the assessments for properties that were initially too high, but did not lower the assessments to the same level as the non-appealed properties.

The last indicator of assessment uniformity is the price related differential. The PRD helps to determine if assessment activities systematically lead to a regressive, proportional, or progressive property tax burden. As previously mentioned, the PRD is an index centered on a value of one and is calculated by dividing the overall mean assessment-to-sales ratio of a jurisdiction by the sum of assessment divided by the sum of sale price (weighted average). Acceptable assessment practices produce a PRD between .98 and 1.03, which indicates that the assessment system is proportional (IAAO, 1999). If the PRD is less than .98, the assessment system is considered progressive. If the PRD is greater than 1.03, the assessment system is considered regressive.

An examination of the PRD for the Broward County 2010 VAB activities reveal that the price related differential for the preliminary and final tax rolls are very similar at 1.0235 and 1.0262, respectively. Based on these overall PRDs, the assessments appear to be proportional. However, the PRD for the appealed preliminary category is noticeably 
higher at 1.0416, which suggests that the appealed properties exhibited signs of regressivity prior to the appeal process. The final appealed PRD indicates that the PRD is lowered to 1.0327, which improved the vertical equity of the appealed properties, but still indicates a slight propensity towards regressivity.

Table 48

Broward County 2010 VAB Ratio Study Statistics

\begin{tabular}{|l|r|r|r|r|r|}
\hline \multicolumn{1}{|c|}{$\begin{array}{c}\text { Sample } \\
\text { Assessment }\end{array}$} & $\begin{array}{c}\text { All } \\
\text { Observations } \\
\text { Preliminary }\end{array}$ & $\begin{array}{c}\text { All } \\
\text { Observations } \\
\text { Final }\end{array}$ & $\begin{array}{c}\text { No Appeal } \\
\text { Preliminary }= \\
\text { Final }\end{array}$ & $\begin{array}{c}\text { Appeal } \\
\text { Preliminary }\end{array}$ & $\begin{array}{c}\text { Appeal } \\
\text { Final }\end{array}$ \\
\hline Mean & 0.893400 & 0.889267 & 0.886249 & 0.933835 & 0.894270 \\
\hline Median & 0.870902 & 0.870561 & 0.870486 & 0.899099 & 0.867044 \\
\hline Weighted Mean & 0.872848 & 0.866559 & 0.864067 & 0.896467 & 0.865945 \\
\hline $\begin{array}{l}\text { Coefficient of } \\
\text { Dispersion }\end{array}$ & 8.046781 & 7.839330 & 7.510942 & 10.071290 & 8.630382 \\
\hline $\begin{array}{l}\text { Price Related } \\
\text { Differential }\end{array}$ & 1.023545 & 1.026205 & 1.025671 & 1.041683 & 1.032710 \\
\hline Number of Ratios & 3705 & 3705 & 3295 & 387 & 387 \\
\hline
\end{tabular}

An examination of the Broward County 2011 and 2012 VAB ratio study statistics revealed patterns similar to the Broward County 2010 VAB ratio study statistics. The mean and median assessment-to-sale ratio and COD statistics all indicated that the preliminary assessments for appealed properties were higher than the assessments of nonappealed properties. Again, the uniformity statistics for final appealed properties were lower than the preliminary appealed statistics, suggesting that the assessment review and appeal process improved assessment uniformity by lowering assessments that were too high. In the same vein, the uniformity statistics of the non-appealed properties were lower than the statistics of the final appealed properties, indicating that appealed assessments could have been lowered further. 
Conversely, the Broward County 2011 and 2012 price-related differential statistics differ from the 2010 tax year. Here, the PRD statistics indicate proportional assessments for all preliminary observations, all final observations, non-appealed observations, and preliminary appealed observations. However, the PRDs for the final appealed observations for the 2011 and 2012 tax years increased relative to the other observation groups, suggesting that the appeal process slightly increased regressivity.

Table 49

Broward County 2011 VAB Ratio Study Statistics

\begin{tabular}{|l|r|r|r|r|r|}
\hline \multicolumn{1}{|c|}{$\begin{array}{c}\text { Sample } \\
\text { Assessment }\end{array}$} & $\begin{array}{c}\text { All } \\
\text { Observations } \\
\text { Preliminary }\end{array}$ & $\begin{array}{c}\text { All } \\
\text { Observations } \\
\text { Final }\end{array}$ & $\begin{array}{c}\text { No Appeal } \\
\text { Preliminary } \\
\text { = Final }\end{array}$ & $\begin{array}{c}\text { Appeal } \\
\text { Preliminary }\end{array}$ & \multicolumn{1}{c|}{$\begin{array}{c}\text { Appeal } \\
\text { Final }\end{array}$} \\
\hline Mean & 0.901719 & 0.900748 & 0.897470 & 0.948696 & 0.936989 \\
\hline Median & 0.881000 & 0.880914 & 0.880690 & 0.911689 & 0.901579 \\
\hline Weighted Mean & 0.887353 & 0.883605 & 0.879515 & 0.921148 & 0.901238 \\
\hline $\begin{array}{l}\text { Coefficient of } \\
\text { Dispersion }\end{array}$ & 8.684847 & 8.634155 & 8.402273 & 11.021579 & 10.729246 \\
\hline $\begin{array}{l}\text { Price Related } \\
\text { Differential }\end{array}$ & 1.016189 & 1.019401 & 1.020414 & 1.029905 & 1.039669 \\
\hline Number of Ratios & 3484 & 3484 & 3195 & 289 & 289 \\
\hline
\end{tabular}

Table 50

Broward County 2012 VAB Ratio Study Statistics

\begin{tabular}{|l|r|r|r|r|r|}
\hline \multicolumn{1}{|c|}{$\begin{array}{c}\text { Sample } \\
\text { Assessment }\end{array}$} & $\begin{array}{c}\text { All } \\
\text { Observations } \\
\text { Preliminary }\end{array}$ & $\begin{array}{c}\text { All } \\
\text { Observations } \\
\text { Final }\end{array}$ & $\begin{array}{c}\text { No Appeal } \\
\text { Preliminary } \\
\text { = Final }\end{array}$ & $\begin{array}{c}\text { Appeal } \\
\text { Preliminary }\end{array}$ & $\begin{array}{c}\text { Appeal } \\
\text { Final }\end{array}$ \\
\hline Mean & 0.907903 & 0.907203 & 0.904868 & 0.946755 & 0.937087 \\
\hline Median & 0.906720 & 0.905653 & 0.903876 & 0.937877 & 0.928950 \\
\hline Weighted Mean & 0.899559 & 0.896820 & 0.892783 & 0.933089 & 0.916795 \\
\hline $\begin{array}{l}\text { Coefficient of } \\
\text { Dispersion }\end{array}$ & 8.033927 & 7.993581 & 8.013835 & 7.853674 & 7.520944 \\
\hline $\begin{array}{l}\text { Price Related } \\
\text { Differential }\end{array}$ & 1.009276 & 1.011578 & 1.013536 & 1.014646 & 1.022133 \\
\hline Number of Ratios & 3684 & 3684 & 3417 & 267 & 267 \\
\hline
\end{tabular}




\section{Summary of Broward County Appeals Analyses}

An examination of the Decision to Appeal descriptive data revealed that appealed parcels were more prevalent in census tracts with higher median home values, higher median incomes, and large percentages of college graduates. In addition, census tracts with a large percentage of black residents were less likely to appeal as compared to the control group: non-appealed parcels. These descriptive statistics are consistent with findings in previous studies (Weber \& McMillen, 2010).

Prior to performing the Firth logit regression, the Decision to Appel Model predicted certain outcomes associated with the relationship between a single-family property owner's decision to appeal, and various variables related to the structure of the property, market activity, assessment practices, and neighborhood demographics. These assumptions were based upon the prior empirical research presented in Chapter Three (see Table 3).

The Decision to Appeal Model indicated a number of the independent variables were statistically significant and consistent with the model's hypotheses. The coefficients on the market value were positive and statistically significant $(\mathrm{p}<0.001)$, indicating that more expensive properties were more likely to be appealed. The exemption variable was significantly negative for all years. $(\mathrm{p}<0.001)$, indicating properties with homestead exemptions were less likely to be appealed. Group Five properties exhibited a positive and statistically significant $(\mathrm{p}<0.001)$ relationship with the decision to appeal. In addition, the variables indicating the percentage of residents without a high school education and the racial composition of a given census tract were all indicated a positive coefficient and were statistically significant $(\mathrm{p}<0.001)$. Contrary 
to the original hypotheses, the building size and sales per census tract indicated the opposite coefficient for all years. The remaining variables provided mixed results, which did not support the stated hypotheses.

The results of the Value Change analysis were also largely mixed. Many of the estimations were consistent for the 2010 and 2011 tax years, but the 2012 tax year often produced conflicting results. For example the total living area exhibited a negative coefficient and was statistically significant $(\mathrm{p}<0.001)$. However, the same variable exhibited a positive coefficient and was deemed statistically insignificant for the 2012 tax year $(\mathrm{p}=.580)$. The coefficients for log of median income per census tract produced similar results. The variable agent indicated that professional representation resulted in a larger percentage decrease in the market value for 2010, but was less effective in obtaining a reduction for the 2011 and 2012 tax years.

Lastly, in terms of assessment uniformity, the sales ratio studies indicated that Broward County’s assessment review and appeal process improved the assessment uniformity of single-family properties in terms of horizontal equity. For every year of the study, the appealed properties exhibited CODs higher than the non-appealed parcels. After the appeal process was completed, the appealed properties exhibited a lower COD. However, the appealed COD’s did not approach the COD of non-appealed parcels. Conversely, the examination of vertical equity indicated that appealed parcels exhibited a slight increase in regressivity, after the appeals process was completed. In other words, higher valued appealed properties exhibited lower assessment-to-sale ratios as compared to lower valued appealed properties. This suggests, on the surface, that higher-valued properties experienced a larger reduction in value. 


\section{CHAPTER VII}

\section{DUVAL COUNTY APPEALS ANALYSES}

\section{Structure and Overview}

This section presents the results of the Duval County appeals analyses. This section emulates the presentation of the Broward County appeal analyses. The appeal activities of single-family property owners in Duval County are analyzed utilizing the Decision to Appeal Model. The section then presents the results of the Value Change Model. Finally, the section presents the traditional indicators of assessment uniformity, to determine whether the appeals activity of single-family property owners improved assessment uniformity in Duval County.

\section{$\underline{\text { Duval County Decision to Appeal Model }}$}

This section examines the appeals activity of single-family property owners in Duval County from 2010 to 2012. During this time, the Duval County Value Adjustment Board received 18,329 value change petitions, of these petitions 6,462 , or $35 \%$ were classified as single-family properties (See Table 51).

Table 51

Duval County VAB Petitions for a Reduction in Value 2010 -2012

\begin{tabular}{|l|r|r|r|r|r|r|}
\hline \multirow{2}{*}{ Duval County } & \multicolumn{2}{c|}{2010} & \multicolumn{2}{c|}{2011} & \multicolumn{2}{c|}{2012} \\
\cline { 2 - 7 } & Total & Percent & Total & Percent & Total & Percent \\
\hline All appealed parcels & 6,322 & $100 \%$ & 7,557 & $100 \%$ & 4,450 & $100 \%$ \\
\hline Appealed single-family parcels & 2,150 & $34 \%$ & 2,462 & $32.6 \%$ & 1,850 & $41.6 \%$ \\
\hline
\end{tabular}

The descriptive statistics (See Table 52) indicate that the total living area for both the appealed and non-appealed parcels were similar and consistent over the study period. There is a noticeable difference in the age of the properties; the appealed properties were 
approximately 45 years old, while the non-appealed properties were around 35 years old. The sales per census tract for the appealed properties are lower than the sales per census tract for the non-appealed properties. The market or just values for the appealed properties are roughly the same as the non-appealed properties. While properties were assessed at a lower value than the previous year, the non-appealed properties regularly experienced a greater reduction year-over-year. Group Five properties appeared in greater quantities when compared to the non-appealed group. In terms of residents of census tracts without a high school diploma, the difference between appealed and non-appealed properties indicated that appealed properties exhibited a higher mean. In terms of the homestead exemption, the appealed properties had less homesteaded properties as compared to the non-appealed properties. The median home value was consistent for both the appealed and non-appealed properties. While, the appealed properties were more likely to come from census tracts which exhibited a higher median income. In a similar vein, appealed parcels where more likely to be found in census tracts with a greater percentage of college graduates. Lastly, in terms of race, appealed properties were more likely to exhibit a greater concentration of black residents when compared to the non-appealed properties. Conversely, appealed parcels exhibited a lower concentration of white residents per census tract, when compared to nonappealed properties.

The thematic maps of single-family parcel appeals per tract (Figures 10, 11, 12) reveal that appealed parcels were clustered around the southern portions (particularly along the St. Johns River and within the I-295 loop) and the eastern portions (Atlantic Beach, Neptune Beach, Jacksonville Beach, and areas along the intra-coastal) of the county. While the total number of single-family appeals declined over the study period, the location of appealed properties appeared to move westward towards the center of the county. 
Table 52

Descriptive Statistics for Duval County Decision to Appeal Model

\begin{tabular}{|c|c|c|c|c|c|c|c|c|c|c|c|c|c|c|c|}
\hline \multirow{3}{*}{$\begin{array}{c}\text { Duval County } \\
\text { Independent Variables }\end{array}$} & \multicolumn{5}{|c|}{2010} & \multicolumn{5}{|c|}{2011} & \multicolumn{5}{|c|}{2012} \\
\hline & \multicolumn{2}{|c|}{ Appealed } & \multicolumn{2}{|c|}{ Non-Appealed } & \multirow[b]{2}{*}{ Z-Score } & \multicolumn{2}{|c|}{ Appealed } & \multicolumn{2}{|c|}{ Non-Appealed } & \multirow[b]{2}{*}{ Z-Score } & \multicolumn{2}{|c|}{ Appealed } & \multicolumn{2}{|c|}{ Non-Appealed } & \multirow[b]{2}{*}{ Z-Score } \\
\hline & Mean & $\begin{array}{l}\text { Std. } \\
\text { Dev. }\end{array}$ & Mean & $\begin{array}{l}\text { Std. } \\
\text { Dev. }\end{array}$ & & Mean & $\begin{array}{l}\text { Std. } \\
\text { Dev. }\end{array}$ & Mean & \begin{tabular}{|l} 
Std. \\
Dev.
\end{tabular} & & Mean & $\begin{array}{l}\text { Std. } \\
\text { Dev. }\end{array}$ & Mean & $\begin{array}{l}\text { Std. } \\
\text { Dev. }\end{array}$ & \\
\hline $\begin{array}{l}\text { LOG TOTAL LIVING } \\
\text { AREA }\end{array}$ & 7.507 & 0.546 & 7.479 & 0.382 & $2.39 * *$ & 7.392 & 0.497 & 7.485 & 0.383 & $16.36 * * *$ & 7.397 & 0.488 & 7.485 & 0.384 & $13.70 * * *$ \\
\hline AGE OF BUILDING & 42.008 & 26.296 & 34.847 & 23.654 & $-12.42 * * *$ & 45.937 & 25.628 & 35.800 & 23.847 & $-19.70 * * *$ & 48.518 & 23.990 & 36.434 & 23.787 & $-21.23 * * *$ \\
\hline RECENT SALE DIRE & 0.026 & 0.200 & 0.052 & 0.313 & $2.62 * * *$ & 0.026 & 0.194 & 0.046 & 0.297 & 1.48 & 0.051 & 0.286 & 0.050 & 0.306 & $-1.77^{*}$ \\
\hline SALES PER TRACT & 31.040 & 37.307 & 43.337 & 52.778 & $13.66^{* * *}$ & 27.426 & 33.077 & 40.150 & 44.457 & $16.62 * * *$ & 24.766 & 27.623 & 38.680 & 39.400 & $17.65 * * *$ \\
\hline LOG PRELIM JV & 11.950 & 0.991 & 11.756 & 0.607 & $-3.95 * * *$ & 11.615 & 0.922 & 11.659 & 0.623 & $10.58 * * *$ & 11.484 & 0.965 & 11.526 & 0.692 & $8.97 * * *$ \\
\hline $\begin{array}{l}\text { \% CHANGE VALUE } \\
\text { PREVIOUS YEAR }\end{array}$ & -0.060 & 0.276 & -0.101 & 0.087 & $-14.16^{* * *}$ & -0.024 & 0.268 & -0.091 & 0.080 & $-14.42 * * *$ & -0.007 & 0.267 & -0.142 & 0.231 & $-26.07 * * *$ \\
\hline GROUP FIVE & 0.208 & 0.406 & 0.125 & 0.331 & $-11.31 * * *$ & 0.258 & 0.438 & 0.124 & 0.329 & $-19.52 * * *$ & 0.261 & 0.439 & 0.140 & 0.347 & $-14.62 * * *$ \\
\hline $\begin{array}{l}\text { PERCENT W/O HS } \\
\text { DEGREE }\end{array}$ & 0.139 & 0.090 & 0.124 & 0.077 & $-6.01 * * *$ & 0.145 & 0.089 & 0.124 & 0.077 & $-10.13 * * *$ & 0.142 & 0.083 & 0.124 & 0.077 & $-9.11 * * *$ \\
\hline EXEMPT & 0.304 & 0.460 & 0.746 & 0.435 & $45.24^{* * *}$ & 0.249 & 0.433 & 0.732 & 0.443 & $51.76^{* * *}$ & 0.247 & 0.431 & 0.727 & 0.445 & $44.91^{* * *}$ \\
\hline $\begin{array}{l}\text { LOG MEDIAN HOME } \\
\text { VALUE PER TRACT }\end{array}$ & 11.873 & 0.544 & 11.876 & 0.440 & $1.885^{*}$ & 11.809 & 0.529 & 11.878 & 0.440 & $8.67 * * *$ & 11.803 & 0.494 & 11.878 & 0.438 & $8.80 * * *$ \\
\hline $\begin{array}{l}\text { LOG MEDIAN } \\
\text { INCOME PER TRACT }\end{array}$ & 10.702 & 0.464 & 10.787 & 0.400 & $8.93 * * *$ & 10.674 & 0.453 & 10.788 & 0.401 & $12.91^{* * *}$ & 10.669 & 0.426 & 10.789 & 0.399 & $13.27 * * *$ \\
\hline $\begin{array}{l}\text { PERCENT W/AT } \\
\text { LEAST BACHELOR }\end{array}$ & 0.263 & 0.168 & 0.259 & 0.147 & $2.125 * *$ & 0.247 & 0.165 & 0.259 & 0.147 & $7.36 * * *$ & 0.244 & 0.160 & 0.259 & 0.147 & $6.74 * * *$ \\
\hline PERCENT TRACT BK & 0.351 & 0.325 & 0.303 & 0.283 & $-3.14 * *$ & 0.360 & 0.316 & 0.305 & 0.284 & $-6.56 * * *$ & 0.364 & 0.314 & 0.303 & 0.282 & $-6.65 * * *$ \\
\hline PERCENT TRACT WT & 0.583 & 0.307 & 0.614 & 0.266 & 1.62 & 0.572 & 0.299 & 0.613 & 0.268 & $4.89 * * *$ & 0.571 & 0.298 & 0.614 & 0.266 & $4.47 * * *$ \\
\hline
\end{tabular}


Figure 10

Duval County 2010 Percent of Single Family Parcels Appealed by Census Tract

\section{Legend}

PERCENT_OF_TOTAL_APPEALS

\begin{tabular}{|l|l|}
\hline & $0.000000-0.002791$ \\
\hline & $0.002792-0.006047$ \\
$0.006048-0.010233$ \\
$0.010234-0.014884$ \\
$0.014885-0.022791$
\end{tabular} 
Figure 11

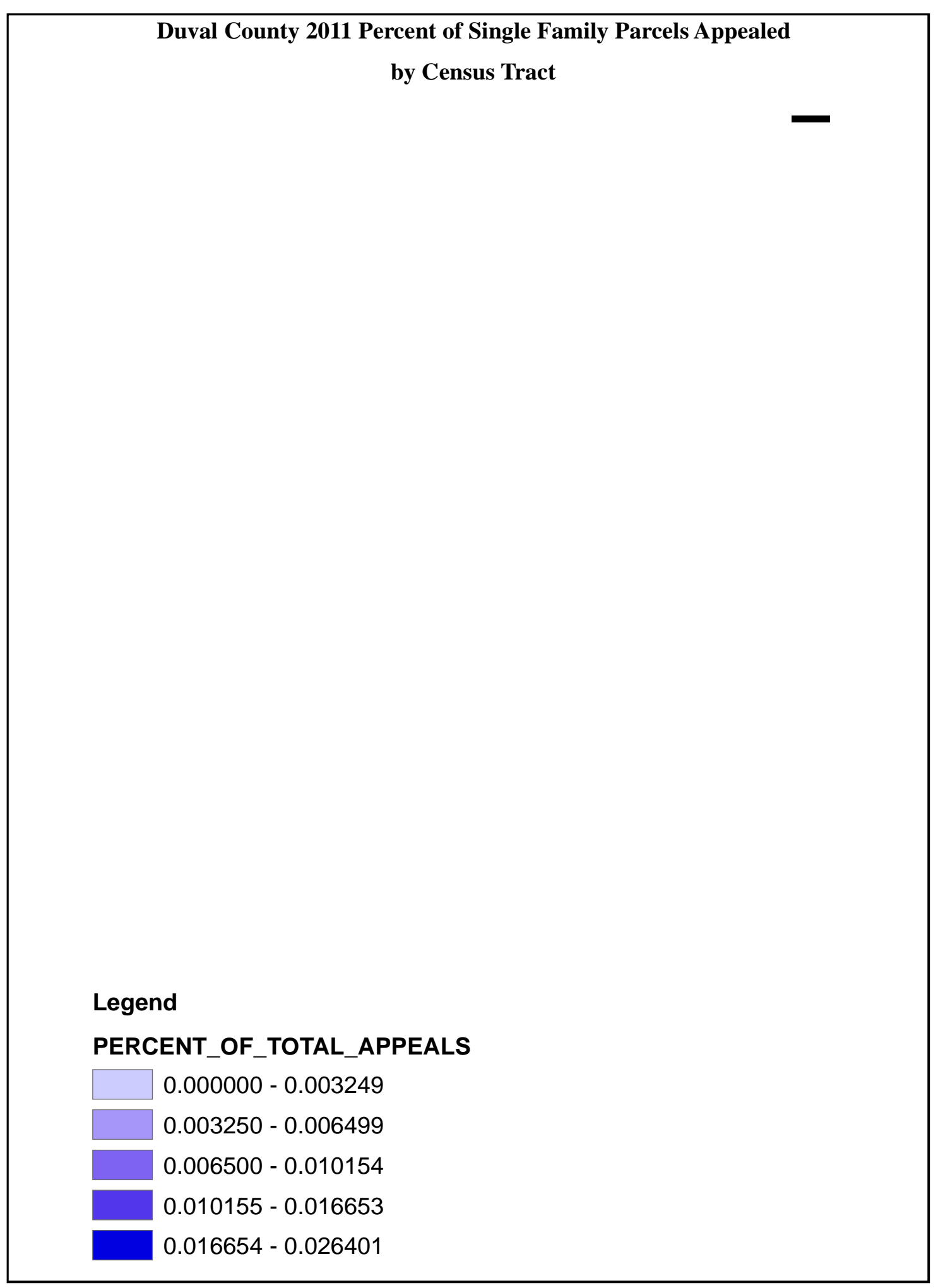


Figure 12

Duval County 2012 Percent of Single Family Parcel Appealed by Census Tract

Legend

PERCENT_OF_TOTAL_APPEALS

$0.000000-0.002703$

$0.002704-0.005405$

$0.005406-0.009189$

$0.009190-0.014595$

$0.014596-0.024324$ 


\section{Duval County Decision to Appeal Model Results}

The results from the Duval County Decision to Appeal Model are presented in Table 53. The table demonstrates the relationship between the independent variables and the probability of filing an appeal. The Decision to Appeal Model indicates that a number of the independent variables exhibited consistent relationships with the dependent variable. During the course of the data analysis concerning the Decision to Appeal Model for Duval County, the same issue concerning the failure to converge was encountered.

Again, after reexamining the data sets, introducing alternative models, and studying the statistical literature concerning the failure of a maximum likelihood regression to converge, it was determined that the number of appeals was too small when compared to the number of non-appealed properties. As a result, a maximum likelihood regression analysis known as the penalized maximum likelihood estimation or Firth Logit was adopted to analyze the Decision to Appeal data sets (Firth, 1993). The Firth Logit regression is utilized to explore rare event data.

The coefficients on the preliminary just values were positive and statistically significant $(\mathrm{p}<0.001)$, indicating that more expensive properties were more likely to be appealed. Similarly, the coefficient for the age of the property was positive and statistically significant $(\mathrm{p}<.001)$, indicating that older properties were more likely to be appealed. The exemption variable was significantly negative for all years. $(p<0.001)$, indicating properties with homestead exemptions were less likely to be appealed. Likewise, the log of the total living area was negative and statistically significant for all three years. Group Five properties exhibited a positive and statistically significant 
$(\mathrm{p}<0.001)$ relationship with the decision to appeal. In addition, the coefficient for sales per tract were negative and statistically significant $(\mathrm{p}<0.001)$, indicating that appeals were more likely come from areas with less market activity. Lastly, the coefficients for percent change in value from the previous year were positive; indicating that a greater change in value prompted appeals activity $(\mathrm{p}<.001)$.

Other variables indicated a consistent coefficient, but were inconsistent in terms of statistical significance; providing only limited evidence of their relationship to the decision to appeal. Recent sales direction indicated a consistent negative relationship, however it was only statistically significant for the 2010, and 2011 tax years. The coefficients for the percent of census tracts for black and white exhibited positive coefficients but were not statistically significant. The remaining variables did not exhibit consistent relationships or statistical strength.

The summary statistics of the Firth Logit Model are consistent over the study period. The Wald Chi-Square tests indicate scores of 2632.1; 2731.79; and 2639.89, with a p-value of .0000 respectively. That is, if none of the independent variables has an impact on appealing a property, the probability of achieving the Wald Chi-Square scores would be less than .0001. Therefore, there is confidence in rejecting the null hypothesis and can conclude that dependent variable, appealed is related to at least one of the independent variables in the population. 
Table 53

Firth Logit Results for Duval County Decision to Appeal Model

\begin{tabular}{|c|c|c|c|c|c|c|c|c|c|}
\hline Duval County & \multicolumn{3}{|c|}{2010} & \multicolumn{3}{|c|}{2011} & \multicolumn{3}{|c|}{2012} \\
\hline Independent Variables & $\begin{array}{c}\text { Estimated } \\
\text { Coefficient }\end{array}$ & $\mathrm{Z}$ & $\mathrm{P}>\mathrm{Z}$ & \begin{tabular}{c|} 
Estimated \\
Coefficient
\end{tabular} & $\mathrm{Z}$ & $\mathrm{P}>\mathrm{Z}$ & \begin{tabular}{c|} 
Estimated \\
Coefficient
\end{tabular} & $\mathrm{Z}$ & $\mathrm{P}>\mathrm{Z}$ \\
\hline LOG TOTAL LIVING AREA & -0.600 & -5.9200 & 0.000 & -0.659 & -6.890 & 0.000 & -0.248 & -2.300 & 0.021 \\
\hline AGE OF BUILDING & 0.005 & 3.9000 & 0.000 & 0.008 & 7.520 & 0.000 & 0.011 & 8.920 & 0.000 \\
\hline RECENT SALE DIRECTION & -0.356 & -3.2300 & 0.001 & -0.333 & -3.310 & 0.001 & -0.008 & -0.090 & 0.928 \\
\hline SALES PER TRACT & -0.003 & -3.8300 & 0.000 & -0.004 & -4.850 & 0.000 & -0.009 & -6.740 & 0.000 \\
\hline LOG PRELIMINARY JUST VALUE & 1.766 & 25.0400 & 0.000 & 1.314 & 18.640 & 0.000 & 0.950 & 12.470 & 0.000 \\
\hline \% CHANGE VALUE PREVIOUS YEAR & 1.588 & 8.2900 & 0.000 & 3.296 & 17.320 & 0.000 & 4.241 & 25.260 & 0.000 \\
\hline GROUP FIVE & 0.743 & 9.0500 & 0.000 & 0.791 & 10.460 & 0.000 & 0.753 & 8.760 & 0.000 \\
\hline PERCENT W/O HS DEGREE & 2.358 & 4.0500 & 0.000 & 1.557 & 2.890 & 0.004 & 0.800 & 1.290 & 0.197 \\
\hline EXEMPT & -2.148 & -39.5200 & 0.000 & -2.163 & -41.370 & 0.000 & -2.108 & -34.760 & 0.000 \\
\hline LOG MEDIAN HOME VALUE PER TRACT & 0.022 & 0.1600 & 0.877 & -0.357 & -2.690 & 0.007 & -0.351 & -2.290 & 0.022 \\
\hline LOG MEDIAN INCOME PER TRACT & -0.173 & -1.2900 & 0.199 & 0.233 & 1.790 & 0.074 & 0.292 & 1.970 & 0.049 \\
\hline PERCENT W/AT LEAST BACHELOR & -0.640 & -1.7500 & 0.080 & 0.005 & 0.010 & 0.988 & -0.181 & -0.460 & 0.649 \\
\hline PERCENT OF TRACT BLACK & 1.634 & 3.3700 & 0.001 & 0.515 & 1.130 & 0.256 & 0.994 & 1.870 & 0.062 \\
\hline PERCENT OF TRACT WHITE & 1.149 & 2.2100 & 0.027 & 0.493 & 1.020 & 0.310 & 0.893 & 1.580 & 0.114 \\
\hline CONSTANT & -18.312 & -9.9400 & 0.000 & -11.478 & -6.690 & 0.000 & -11.377 & -5.650 & 0.000 \\
\hline & Number of obs & & 56,650 & Number of obs & & 56,991 & Number of obs & & 56,552 \\
\hline & Wald chi2(14) & & 2632.1 & Wald chi2(14) & & 31.79 & Wald chi2(14) & & 639.89 \\
\hline & Prob $>$ chi2 & & 0.0000 & Prob > chi2 & & .0000 & Prob > chi2 & & 0.0000 \\
\hline & $\begin{array}{l}\text { Penalized } \\
\text { Log-likelihood }\end{array}$ & -737 & 71.1662 & $\begin{array}{l}\text { Penalized } \\
\text { Log-likelihood }\end{array}$ & -8239 & .7719 & $\begin{array}{l}\text { Penalized } \\
\text { Log-likelihood }\end{array}$ & -6351 & 1.4528 \\
\hline
\end{tabular}




\section{Duval County Value Change Model}

As compared to the Broward County Value Change Model, the Duval County Value Change Model presented more consistent descriptive statistics over the study period. In fact, every variable exhibited a consistent relationship, in terms of the mean, between the group of properties that did and did not receive a reduction. Table 55 suggests that the reduction and no reduction properties are significantly different on nearly every variable (with above average quality construction, sales direction, and agent being the exceptions).

In terms of properties' structural characteristics, the data suggests that properties that received a reduction were of average or below average construction quality, older, and smaller than properties that did not receive a reduction. In terms of market influences, the data suggests properties that did receive a reduction came from census tracts with less sales activity. In addition, successfully appealed parcels were more likely to come from census tracts with lower median home values.

The assessment variables indicate that on average, all of the appealed properties experienced a reduction in the preliminary market value when compared to the previous tax year. However, the successfully appealed properties, on average, experienced less of a reduction in their preliminary market values when compared to the properties that failed to receive a reduction. In addition the log of the preliminary just value variable indicates that successfully appealed properties were less expensive when compared to properties that did not receive a reduction. Properties, which were excluded from the PTOP's initial sales qualification analysis (classified as Group Five), occurred more frequently as successfully appealed parcels. 
In terms of the demographics, the data indicated that properties more successful in achieving a reduction came from census tracts with lower median incomes, a lower percentage of college graduates, and a greater percentage of minority populations. Lastly, properties represented by professionals were less successful in achieving a reduction. For all three years, the mean value for properties receiving a reduction through an agent was less than those properties that did not receive a reduction. Overall, the use of agents ranged from 15\% - 22\% during the study period (Table 54).

Table 54

Duval County Property Owner Use of Professional Representation 2010-2012

\begin{tabular}{|l|r|r|r|r|r|r|}
\cline { 2 - 7 } & \multicolumn{2}{|c|}{2010} & \multicolumn{2}{c|}{2011} & \multicolumn{2}{c|}{2012} \\
\cline { 2 - 7 } Representational & Frequency & Percentage & Frequency & Percentage & Frequency & Percentage \\
\hline No & 1,738 & $80.84 \%$ & 2,085 & $84.69 \%$ & 1,433 & $77.46 \%$ \\
\hline Yes & 412 & $19.16 \%$ & 377 & $15.31 \%$ & 417 & $22.54 \%$ \\
\hline Total & 2,150 & $100.00 \%$ & 2,462 & $100.00 \%$ & 1,850 & $100.00 \%$ \\
\hline
\end{tabular}

The previous maps of single-family parcel appeals per tract (Figures 10, 11, 12)

revealed that appealed parcels were clustered around the southern portions (particularly along the St. Johns River) and the eastern portions (Atlantic Beach, Neptune Beach, Jacksonville Beach, and areas along the intra-coastal) of the county. While the total number of single-family appeals declined over the study period, the location of the appealed properties appeared to move westward towards the center of the county. In terms of achieving a value change through participation in the appeal process, the following maps (Figures $13,14,15$ ) indicate that a majority of the single-family properties, which filed an appeal in Duval County, received some type of reduction in market value over the three-year period. The higher concentrations of reductions per census tract, took place in the center of the county, while the lower concentrations of reductions per census tract took place in the southeast portion of the county. 
Table 55

Descriptive Statistics for Duval County Value Change Model

\begin{tabular}{|c|c|c|c|c|c|c|c|c|c|c|c|c|c|c|c|}
\hline \multirow{3}{*}{\begin{tabular}{|c|} 
Duval County \\
Independent Variables
\end{tabular}} & \multicolumn{5}{|c|}{2010} & \multicolumn{5}{|c|}{2011} & \multicolumn{5}{|c|}{2012} \\
\hline & \multicolumn{2}{|c|}{ Reduction } & \multicolumn{2}{|c|}{ No Reduction } & \multirow[b]{2}{*}{ Z-Score } & \multicolumn{2}{|c|}{ Reduction } & \multicolumn{2}{|c|}{ No Reduction } & \multirow[b]{2}{*}{ Z-Score } & \multicolumn{2}{|c|}{ Reduction } & \multicolumn{2}{|c|}{ No Reduction } & \multirow[b]{2}{*}{ Z-Score } \\
\hline & Mean & $\begin{array}{l}\text { Std. } \\
\text { Dev. }\end{array}$ & Mean & $\begin{array}{l}\text { Std. } \\
\text { Dev. }\end{array}$ & & Mean & $\begin{array}{l}\text { Std. } \\
\text { Dev. }\end{array}$ & Mean & $\begin{array}{l}\text { Std. } \\
\text { Dev. }\end{array}$ & & Mean & $\begin{array}{l}\text { Std. } \\
\text { Dev. }\end{array}$ & Mean & $\begin{array}{l}\text { Std. } \\
\text { Dev. }\end{array}$ & \\
\hline AVERAGE QUALITY & 0.778 & 0.010 & 0.766 & 0.018 & -0.63 & 0.778 & 0.009 & 0.735 & 0.027 & -1.61 & 0.709 & 0.012 & 0.662 & 0.027 & $-1.65 *$ \\
\hline $\begin{array}{l}\text { BELOW AVERAGE } \\
\text { QUALITY }\end{array}$ & 0.036 & 0.005 & 0.019 & 0.006 & $-2.04 * *$ & 0.065 & 0.005 & 0.036 & 0.011 & $-1.86^{*}$ & 0.170 & 0.010 & 0.110 & 0.018 & $-2.60 * * *$ \\
\hline LOG TOTAL LIVING & 7.449 & 0.014 & 7.663 & 0.022 & $8.76 * * *$ & 7.361 & 0.011 & 7.638 & 0.027 & $10.15^{* * *}$ & 7.362 & 0.012 & 7.572 & 0.030 & $6.92 * * *$ \\
\hline AGE OF BUILDING & 45.125 & 0.661 & 33.572 & 1.028 & $-9.06 * * *$ & 46.923 & 0.544 & 37.836 & 1.564 & $-5.62 * * *$ & 50.018 & 0.592 & 41.013 & 1.489 & $-5.81 * * *$ \\
\hline RECENT SALE DIRE & 0.021 & 0.004 & 0.038 & 0.011 & 0.93 & 0.025 & 0.004 & 0.036 & 0.015 & 0.26 & 0.032 & 0.005 & 0.146 & 0.029 & $4.76 * * *$ \\
\hline SALES PER TRACT & 27.897 & 0.864 & 39.548 & 1.804 & $8.69 * * *$ & 26.268 & 0.686 & 36.625 & 2.365 & $6.50 * * *$ & 23.063 & 0.652 & 33.292 & 1.985 & $6.01 * * *$ \\
\hline LOG PRELIM JV & 11.897 & 0.026 & 12.110 & 0.038 & $5.91 * * *$ & 11.573 & 0.020 & 11.950 & 0.053 & $7.98 * * *$ & 11.434 & 0.024 & 11.736 & 0.056 & $5.44 * * *$ \\
\hline $\begin{array}{l}\text { \% CHANGE VALUE } \\
\text { PREVIOUS YEAR }\end{array}$ & -0.049 & 0.008 & -0.089 & 0.004 & $-3.58 * * *$ & -0.018 & 0.006 & -0.068 & 0.013 & $-2.88 * * *$ & -0.003 & 0.007 & -0.056 & 0.013 & $-2.67 * * *$ \\
\hline GROUP FIVE & 0.241 & 0.011 & 0.121 & 0.014 & $-6.08 * * *$ & 0.275 & 0.010 & 0.116 & 0.194 & $-5.71 * * *$ & 0.280 & 0.011 & 0.169 & 0.021 & $-4.04 * * *$ \\
\hline EXEMPT & 0.261 & 0.011 & 0.421 & 0.021 & $7.17 * * *$ & 0.226 & 0.009 & 0.436 & 0.030 & $7.62 * * *$ & 0.219 & 0.011 & 0.383 & 0.028 & $6.09 * * *$ \\
\hline $\begin{array}{l}\text { LOG MEDIAN HOME } \\
\text { VALUE PER TRACT }\end{array}$ & 11.825 & 0.014 & 12.001 & 0.020 & $7.49 * * *$ & 11.784 & 0.011 & 12.008 & 0.029 & $6.93 * * *$ & 11.774 & 0.012 & 11.949 & 0.028 & $5.71 * * *$ \\
\hline $\begin{array}{l}\text { LOG MEDIAN } \\
\text { INCOME PER TRACT }\end{array}$ & 10.649 & 0.012 & 10.847 & 0.017 & $8.96 * * *$ & 10.651 & 0.010 & 10.862 & 0.024 & $7.09 * * *$ & 10.641 & 0.011 & 10.806 & 0.023 & $6.36 * * *$ \\
\hline $\begin{array}{l}\text { PERCENT W/AT } \\
\text { LEAST BACHELOR }\end{array}$ & 0.246 & 0.004 & 0.307 & 0.007 & $7.86 * * *$ & 0.240 & 0.004 & 0.302 & 0.010 & $6.52 * * *$ & 0.236 & 0.004 & 0.285 & 0.009 & $5.04 * * *$ \\
\hline PERCENT TRACT BK & 0.387 & 0.008 & 0.252 & 0.011 & $-7.79 * * *$ & 0.375 & 0.007 & 0.240 & 0.015 & $-6.87 * * *$ & 0.385 & 0.008 & 0.261 & 0.016 & $-6.39 * * *$ \\
\hline $\begin{array}{l}\text { PERCENT TRACT } \\
\text { WT }\end{array}$ & 0.552 & 0.008 & 0.667 & 0.011 & $6.78 * * *$ & 0.558 & 0.006 & 0.684 & 0.015 & $6.59 * * *$ & 0.551 & 0.008 & 0.672 & 0.015 & $6.61^{* * *}$ \\
\hline AGENT & 0.178 & 0.010 & 0.229 & 0.017 & $2.70 * * *$ & 0.152 & 0.008 & 0.164 & 0.022 & 0.51 & 0.207 & 0.010 & 0.318 & 0.027 & $4.27 * * *$ \\
\hline
\end{tabular}

Z-Score reflects z-statistics from the Wilcoxon rank sum test for assessing whether the groups are significantly different on the corresponding variable. $*, * *, * * *$ indicates statistical significance at $10 \%, 5 \%, 1 \%$ respectively, using a two-tailed test. 
Figure 13

Duval County 2010 Percent of Successful Single Family Parcel Appeals by Census Tract

\section{Legend}

PERCENT_REDUCED_WITHIN_TRACT

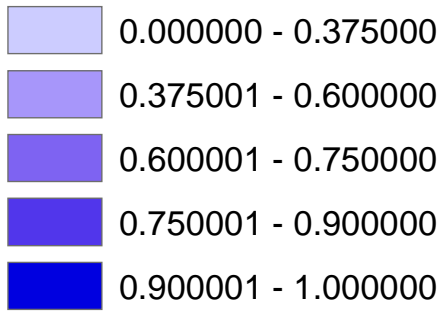


Figure 14

Duval County 2011 Percent of Successful Single Family Parcel Appeals by Census Tract

\section{Legend}

PERCENT_REDUCED_WITHIN_TRACT

$0.000000-0.375000$

$0.375001-0.666667$

$0.666668-0.857143$

$0.857144-0.956522$

$0.956523-1.000000$ 
Figure 15

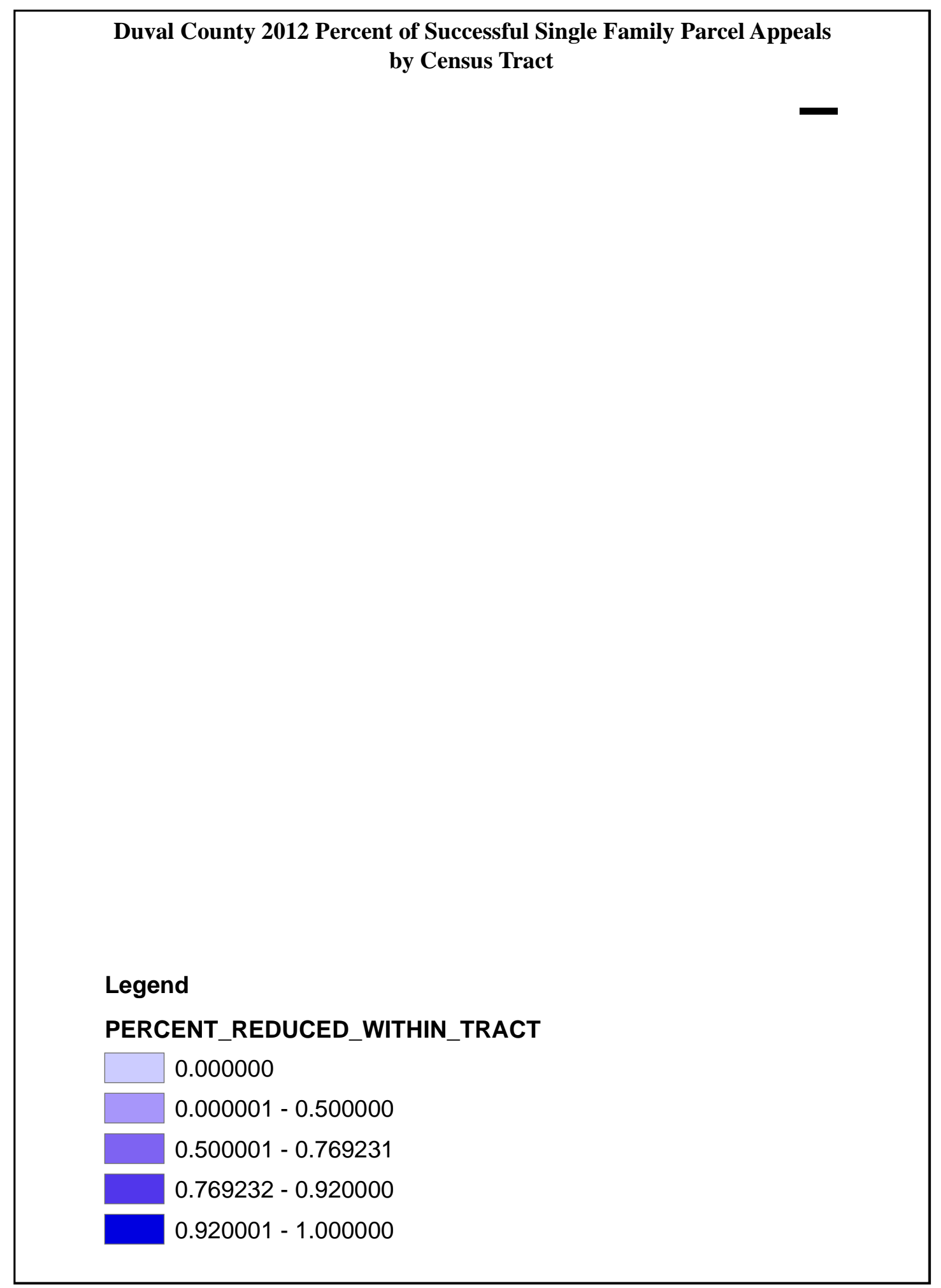




\section{$\underline{\text { Duval County Value Change Model Results }}$}

Table 56 presents the maximum likelihood regression results for the Duval County Value Change Model which examined the effects structural, market, assessment, and demographic variables may have on the extent of a reduction single-family properties obtained by participating in the assessment review and appeal process.

The Duval County Value Change Model indicated a few consistent and statistically significant relationships between the dependent and independent variables. For all years, the total living area coefficient was negative and statistically significant $(\mathrm{p}<0.001)$. This suggests that, all else being equal, the percentage appeals adjustment decreases as a property's total building area increases. In addition, the coefficient for the preliminary just value or market value is significantly positive for all years $(\mathrm{p}<0.001)$. This suggests that percentage appeals adjustments are larger for homes that are more expensive. In addition, the coefficients for the percentage change in market value are positive for all three years, which suggests that the change in the market value year-overyear is directly related to the percentage change in market value achieved at the value adjustment board. Lastly, the exemption coefficient is significantly negative $(\mathrm{p}<0.001)$ during the entire study period. This suggests that the percentage change in market value is less if the property has a homestead exemption.

The remaining variables provided less conclusive information. In some instances, the variables produced mixed results, while others were completely inconclusive. For 2010, the quality construction coefficients are negative. The reverse is true for the 2011 tax year, with positive coefficients. For the 2012 tax year, above average properties exhibit a positive coefficient, while average properties exhibit a negative coefficient. The 
coefficient for the age of the building is significantly positive for 2010 and 2012 ( $\mathrm{p}<0.001)$, but only marginally significant for $2011(\mathrm{p}=.381)$. This suggests that the percentage appeals adjustments are larger for older homes.

Many of the variables exhibit consistent coefficient directions, but were deemed statistically insignificant. For example, the coefficients for properties classified as group five and percent of census tract without a high school degree are positive for all three years. The coefficient for Recent Sale Direction is negative for the entire study period. However, the coefficient is not statistically significant for the 2010 and 2011 tax years. These consistent coefficients suggest that the percentage of value changes were greater for properties that were excluded from the initial PTOP sales studies and for properties located in areas with a lower percentage of high school graduates. In addition, properties with recent sales were likely to receive a smaller reduction as compared to properties that had not recently sold.

The coefficients estimates for the median home value per census tract, the median income per census tract, the percentage of college graduates per census tract, the percentage black per census tract, and the percentage white are all inconsistent over the study period, with most lacking any statistical significance. The coefficient for agent is negative for all years of the study. Indicating that professional representative were less effective, as compared to homeowners that represented themselves, in obtaining value changes. However, the coefficient for agent is only statistically significant for the 2012 tax year. 
Table 56

Duval County MLE Regression Results for Percentage Change in Market Value

\begin{tabular}{|c|c|c|c|c|c|c|c|c|c|}
\hline Duval County Heckman Selection Model & \multicolumn{3}{|l|}{2010} & \multicolumn{3}{|c|}{2011} & \multicolumn{3}{|c|}{2012} \\
\hline Independent Variables & \begin{tabular}{l|l} 
Est. Coefficient \\
\end{tabular} & $\mathrm{Z}$ & $\mathrm{P}>\mathrm{Z}$ & Est. Coefficient & $\mathrm{Z}$ & $\mathrm{P}>\mathrm{Z}$ & Est. Coefficient & $\mathrm{z}$ & $\mathrm{P}>\mathrm{Z}$ \\
\hline ABOVE AVERAGE QUALITY & -0.463 & -2.02 & 0.043 & 0.154 & 0.70 & 0.485 & $\begin{array}{r}0.087 \\
\end{array}$ & 0.45 & 0.650 \\
\hline AVERAGE QUALITY & -0.695 & -3.28 & 0.001 & 0.109 & 0.56 & 0.578 & -0.026 & -0.19 & 0.851 \\
\hline BELOW AVERAGE QUALITY & 0 (omitted) & & & 0 (omitted) & & & 0 (omitted) & & \\
\hline LOG TOTAL LIVING AREA & -0.894 & -6.80 & 0.000 & -0.853 & -5.22 & 0.000 & -0.826 & -4.51 & 0.000 \\
\hline AGE OF BUILDING & 0.007 & 4.49 & 0.000 & 0.002 & 0.88 & 0.381 & 0.006 & 3.26 & 0.001 \\
\hline RECENT SALE DIRECTION & -0.134 & -0.90 & 0.368 & -0.133 & -0.84 & 0.402 & -0.343 & -2.98 & 0.003 \\
\hline SALES PER TRACT & -0.0002 & -0.20 & 0.838 & -0.0005 & 0.42 & 0.677 & -0.003 & -1.63 & 0.104 \\
\hline LOG PRELIMINARY JUST VALUE & 0.659 & 7.14 & 0.000 & 0.411 & 3.85 & 0.000 & 0.573 & 4.79 & 0.000 \\
\hline \% CHANGE VALUE PREVIOUS YEAR & 0.954 & 3.38 & 0.001 & 0.386 & 1.92 & 0.055 & 0.469 & 2.98 & 0.003 \\
\hline GROUP FIVE & 0.077 & 0.69 & 0.492 & 0.336 & 2.30 & 0.021 & 0.024 & 0.18 & 0.858 \\
\hline PERCENT W/O HS DEGREE & 1.425 & 1.79 & 0.074 & 0.554 & 0.57 & 0.568 & 1.472 & 1.52 & 0.128 \\
\hline EXEMPT & -0.087 & -1.08 & 0.281 & -0.111 & -1.16 & 0.245 & -0.118 & -1.19 & 0.232 \\
\hline LOG MEDIAN HOME VALUE PER TRACT & 0.245 & 1.33 & 0.185 & -0.072 & -0.31 & 0.754 & -0.146 & -0.61 & 0.539 \\
\hline LOG MEDIAN INCOME PER TRACT & 0.068 & 0.39 & 0.693 & -0.248 & -1.17 & 0.242 & 0.303 & 1.35 & 0.177 \\
\hline PERCENT W/AT LEAST BACHELOR & -1.727 & -3.53 & 0.000 & 0.116 & 0.20 & 0.845 & 0.069 & 0.11 & 0.913 \\
\hline PERCENT OF TRACT BLACK & 2.037 & 3.18 & 0.001 & -0.188 & -0.26 & 0.795 & -0.943 & -1.19 & 0.233 \\
\hline PERCENT OF TRACT WHITE & 1.601 & 2.34 & 0.019 & -0.228 & -0.30 & 0.766 & -1.813 & -2.17 & 0.030 \\
\hline AGENT & -0.049 & -0.63 & 0.529 & -0.011 & -0.10 & 0.917 & -0.307 & -3.57 & 0.000 \\
\hline CONSTANT & -5.034 & -2.10 & 0.036 & 6.331 & 2.12 & 0.034 & 0.191 & 0.06 & 0.952 \\
\hline \multicolumn{10}{|l|}{ mills } \\
\hline lambda & 0.0672 & 3.77 & 0.000 & -0.274 & -1.32 & 0.185 & 0.0277 & 2.33 & 0.020 \\
\hline \multicolumn{10}{|c|}{ note: BELOW AVERAGE QUALITY omitted because of collinearity } \\
\hline & \begin{tabular}{|l|l} 
Number of obs & \\
\end{tabular} & & 2106 & 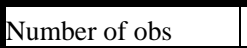 & & 2426 & Number of obs & & 1817 \\
\hline & Censored obs & & 537 & Censored obs & & 225 & Censored obs & & 265 \\
\hline & Uncensored obs & & 1569 & Uncensored obs & & 2201 & Uncensored obs & & 1552 \\
\hline & Wald chi2(14) & & 2985.520 & Wald chi2(14) & & 8027.150 & Wald chi2(14) & & 515626.800 \\
\hline & \begin{tabular}{l|l} 
Prob $>$ chi2 & \\
\end{tabular} & & 0.0000 & Prob > chi2 & & 0.0000 & Prob > chi2 & & 0.0000 \\
\hline & \multicolumn{3}{|c|}{ two-step est. of rho $=1.50$ truncated to 1} & \multicolumn{3}{|c|}{ two-step est. of rho $=-2.00$ truncated to -1} & \multicolumn{3}{|c|}{ two-step est. of rho $=1.44$ truncated to 1} \\
\hline
\end{tabular}




\section{Duval County Assessment Uniformity Results}

As mentioned in the previous chapters, a unique characteristic of the property tax is that it is based upon an assessor's opinion of value, rather than being directly observed from market transactions (i.e., sales tax). The industry standard by which to judge the accuracy of assessment activities is to compare the assessments derived by the property appraiser to the actual sales price of a given property. As a result, recent sales data serve as a critical element in evaluating the uniformity of property tax assessments.

In order to determine the effect of single-family appeals activity on the assessment uniformity of single-family properties located in Duval County, separate ratio studies were conducted for each year of the study period. Following the IAAO's Standard on Ratio Studies and the State of Florida's statutory requirements for property tax assessments, the ratio studies only included qualified sales, which occurred a year prior to the respective tax year's assessment date (January $\left.1^{\text {st }}\right)$. As a result of applying these criteria to the Duval County sample data, a total of 4,465 qualified sales were identified, of which 1,535 were from 2010, 1,385 from 2011, and 1,554 from 2012.

Again, each of the identified sales was matched to their respective assessed value to create assessment-to-sale ratios. Nonparametric procedures were then used to eliminate statistical outliers for each tax year (IAAO, 2010). The lower bound for trimming outliers was the $25^{\text {th }}$ percentile minus three times the interquartile range, and the upper bound was the $75^{\text {th }}$ percentile plus three times the interquartile range. Table 58 indicates the critical ratio values used for trimming the statistical outliers. The assessment-to-sale ratios were based on the preliminary assessed values and final assessed values for each tax year. Based on these critical values, any observation less 
than the lower bound, or greater than the upper bound, was eliminated from the ratio study analysis. Combined, the outlier trimming procedure removed 128 sales from the sample leaving 4,337 observations in the Duval County assessment uniformity data set.

Table 57

Duval County VAB Ratio Study Outlier Trimming 2010-2012

\begin{tabular}{|l|c|c|r|r|r|r|}
\hline & \multicolumn{2}{|c|}{2010} & \multicolumn{2}{c|}{2011} & \multicolumn{2}{c|}{2012} \\
\cline { 2 - 7 } & $\begin{array}{c}\text { Assessment- } \\
\text { to-Sale } \\
\text { Ratio Based } \\
\text { on Initial } \\
\text { Assessed } \\
\text { Value }\end{array}$ & $\begin{array}{c}\text { Assessment- } \\
\text { to-Sale Ratio } \\
\text { Based on } \\
\text { Final } \\
\text { Assessed } \\
\text { Value }\end{array}$ & $\begin{array}{c}\text { Assessment- } \\
\text { to-Sale } \\
\text { Ratio Based } \\
\text { on Initial } \\
\text { Assessed } \\
\text { Value }\end{array}$ & $\begin{array}{c}\text { Assessment- } \\
\text { to-Sale Ratio } \\
\text { Based on Final } \\
\text { Assessed } \\
\text { Value }\end{array}$ & $\begin{array}{c}\text { Assessment- } \\
\text { to-Sale Ratio } \\
\text { Based on } \\
\text { Initial } \\
\text { Assessed } \\
\text { Value }\end{array}$ & $\begin{array}{c}\text { Assessment- } \\
\text { to-Sale } \\
\text { Ratio Based } \\
\text { on Final } \\
\text { Assessed } \\
\text { Value }\end{array}$ \\
\hline 1st percentile & 0.6141125 & 0.5988212 & 0.6433667 & 0.6432658 & 0.6545823 & 0.6545823 \\
\hline 25th percentile & 0.8283561 & 0.8268395 & 0.8050851 & 0.8041763 & 0.8161006 & 0.8156207 \\
\hline Median & 0.8840286 & 0.8832133 & 0.8598685 & 0.8580925 & 0.8673766 & 0.8658099 \\
\hline 75th percentile & 0.9396822 & 0.9389443 & 0.9227614 & 0.9189 & 0.9477427 & 0.9429229 \\
\hline 99th percentile & 1.76098 & 1.751211 & 1.584712 & 1.282832 & 1.976333 & 1.87852 \\
\hline $\begin{array}{l}\text { Lower bound for } \\
\text { trimming }\end{array}$ & 0.4943778 & 0.4905251 & 0.4520562 & 0.4600052 & 0.4211743 & 0.4337141 \\
\hline $\begin{array}{l}\text { Upper bound for } \\
\text { trimming }\end{array}$ & 1.2736605 & 1.2752587 & 1.2757903 & 1.2630711 & 1.342669 & 1.3248295 \\
\hline
\end{tabular}

Five groups of assessment-to-sale ratio statistics were produced for the Duval County sample set. Each group reflects the traditional assessment uniformity metrics: mean, median, weighted mean, coefficient of dispersion, and the price related differential (see Chapter Two for further discussion).

The first group provided statistics for the preliminary tax roll. These statistics reflect the uniformity statistics of all sales observations prior to any review. The second group of statistics reflects the uniformity statistics of all observations after the appeal process has been completed. In addition to the preliminary and final assessed value uniformity statistics, the data was further stratified to reflect non-appealed and appealed statistics. The third group reflects the uniformity statistics for which no appeal was filed. 
While the fourth and fifth groups identified the pre-appeal and post-appeal ratio statistics for appealed properties.

Tables 58 through 60 provide the assessment-to-sale ratio statistics for the 2010, 2011, and 2012 tax years. For the 2010 tax year, the mean initial assessment-to-sale ratio for the preliminary tax roll was $88.2 \%$, while the median assessment-to-sale ratio was 88.2\%. The mean and median are $88.0 \%$ and $88.1 \%$ for all final observations. The nonappealed parcels reflect a similar mean and median of $88 \%$ and $88 \%$.

The statistics for the appeal preliminary category reveal that the mean assessmentto-sale ratio for the appealed properties was $98.8 \%$, while the median assessment-to-sale ratio was $96.8 \%$. In addition, the mean and median assessment-to-sale ratios for the appeal final group were $88 \%$ and $89.5 \%$, respectively. These mean and median assessment-to-sale ratio statistics were higher than the mean and median assessment-tosale ratio statistics for the non-appealed group.

The comparison of the non-appealed ratios with the appealed preliminary ratios, for the 2010 tax year, suggests that appealed properties had higher preliminary property tax assessments. Here, the mean assessment-to-sale ratio for final appealed properties (88\%) was equal to the mean assessment-to-sale ratio for non-appealed properties (88\%). This pattern suggests that the appeal process lowered the assessments for properties that were initially too high to the same level of non-appealed properties.

A comparison of the coefficient of dispersion for the five groups reveals that the assessment review and appeal process lowered the degree of variability in property tax assessments for the 2010 tax year; across all observations in the sample, the COD fell slightly from 8.05 to 7.97 . When the sample was further divided into the non-appealed 
and appealed groups, a pronounced difference in the preliminary CODs was revealed; the preliminary non-appealed COD indicated a 7.95, while the preliminary appealed COD was 11.05. Once the appealed properties completed the assessment review and appeal process, the COD for appealed parcels declined from 11.05 to 9.44. The COD of the final appealed parcels was higher than the COD of the non-appealed parcels suggesting that appeals process lowered the assessments for properties that were initially too high, but perhaps did not lower the assessment enough.

The last indicator of assessment uniformity is the price related differential. The PRD helps to determine if assessment activities systematically lead to a regressive, proportional, or progressive property tax burden. Again, the PRD is an index centered on a value of one, and is calculated by dividing the overall mean assessment-to-sales ratio of a jurisdiction by the sum of assessment divided by the sum of sale price (weighted average). Acceptable assessment practices produce a PRD between .98 and 1.03, which indicates that the assessment system is proportional (IAAO, 1999). If the PRD is less than .98, the assessment system is considered progressive. If the PRD is greater than 1.03, the assessment system is considered regressive.

An examination of the PRD for the Duval County 2010 VAB activities reveal that the price related differential for the preliminary and final tax rolls were very similar at 1.012 and 1.013, respectively. Based on the overall PRDs, the assessments appear to be proportional. Further examination of the remaining comparison groups revealed that the assessments are indeed proportional; the non-appealed PRD was 1.013, the preliminary appealed PRD was 1.0268, and the final appealed PRD was even lower at 1.007146. 
Table 58

Duval County 2010 VAB Ratio Study Statistics

\begin{tabular}{|l|r|r|r|r|r|}
\hline \multicolumn{1}{|c|}{$\begin{array}{c}\text { Sample } \\
\text { Assessment }\end{array}$} & $\begin{array}{c}\text { All } \\
\text { Observations } \\
\text { Preliminary }\end{array}$ & $\begin{array}{c}\text { All } \\
\text { Observations } \\
\text { Final }\end{array}$ & $\begin{array}{c}\text { No Appeal } \\
\text { Preliminary }= \\
\text { Final }\end{array}$ & $\begin{array}{c}\text { Appeal } \\
\text { Preliminary }\end{array}$ & \multicolumn{1}{c|}{$\begin{array}{c}\text { Appeal } \\
\text { Final }\end{array}$} \\
\hline Mean & 0.882554 & 0.880535 & 0.880529 & 0.988431 & 0.880840 \\
\hline Median & 0.882072 & 0.881412 & 0.880681 & 0.968487 & 0.895398 \\
\hline Weighted Mean & 0.871594 & 0.868633 & 0.868425 & 0.962575 & 0.874590 \\
\hline $\begin{array}{l}\text { Coefficient of } \\
\text { Dispersion }\end{array}$ & 8.058510 & 7.979333 & 7.951073 & 11.052316 & 9.448149 \\
\hline $\begin{array}{l}\text { Price Related } \\
\text { Differential }\end{array}$ & 1.012575 & 1.013702 & 1.013938 & 1.026861 & 1.007146 \\
\hline Number of Ratios & 1492 & 1492 & 1464 & 28 & 28 \\
\hline
\end{tabular}

An examination of the Duval County 2011 and 2012 VAB ratio study statistics

revealed patterns similar to the Duval County 2010 VAB ratio study statistics. The mean and median assessment-to-sale ratio and COD statistics all indicated that the preliminary assessments for appealed properties were higher than the assessments of non-appealed properties. Again, the uniformity statistics for final appealed properties were lower than the preliminary appealed statistics and non-appealed statistics, suggesting that Duval County’s assessment review and appeal process improved assessment uniformity by lowering high assessments to the levels of non-appealed properties.

An examination of the Duval County 2011 and 2012 price-related differential statistics produced mixed results. For 2011, the PRD statistics indicate proportional assessments for all preliminary observations, all final observations, and non-appealed observations. However, the PRD for the preliminary appealed observations (1.0396) exhibited signs of regressivity. The PRD was subsequently lowered towards a more proportional level (1.0267) after the appeal process. For 2012, the PRD statistics exhibited similar indicators of proportionality for all comparison groups. 
Table 59

Duval County 2011 VAB Ratio Study Statistics

\begin{tabular}{|l|r|r|r|r|r|}
\hline \multicolumn{1}{|c|}{$\begin{array}{c}\text { Sample } \\
\text { Assessment }\end{array}$} & $\begin{array}{c}\text { All } \\
\text { Observations } \\
\text { Preliminary }\end{array}$ & $\begin{array}{c}\text { All } \\
\text { Observations } \\
\text { Final }\end{array}$ & $\begin{array}{c}\text { No Appeal } \\
\text { Preliminary }= \\
\text { Final }\end{array}$ & $\begin{array}{c}\text { Appeal } \\
\text { Preliminary }\end{array}$ & $\begin{array}{c}\text { Appeal } \\
\text { Final }\end{array}$ \\
\hline Mean & 0.868937 & 0.865169 & 0.864766 & 1.017967 & 0.879596 \\
\hline Median & 0.858649 & 0.856595 & 0.856445 & 1.062491 & 0.862388 \\
\hline Weighted Mean & 0.861441 & 0.856557 & 0.856553 & 0.979151 & 0.856673 \\
\hline $\begin{array}{l}\text { Coefficient of } \\
\text { Dispersion }\end{array}$ & 8.626381 & 8.369022 & 8.333663 & 10.887956 & 9.547391 \\
\hline $\begin{array}{l}\text { Price Related } \\
\text { Differential }\end{array}$ & 1.008701 & 1.010054 & 1.009588 & 1.039643 & 1.026758 \\
\hline Number of Ratios & 1359 & 1359 & 1322 & 37 & 37 \\
\hline
\end{tabular}

Table 60

Duval County 2012 VAB Ratio Study Statistics

\begin{tabular}{|l|r|r|r|r|r|}
\hline \multicolumn{1}{|c|}{$\begin{array}{c}\text { Sample } \\
\text { Assessment }\end{array}$} & $\begin{array}{c}\text { All } \\
\text { Observations } \\
\text { Preliminary }\end{array}$ & $\begin{array}{c}\text { All } \\
\text { Observations } \\
\text { Final }\end{array}$ & $\begin{array}{c}\text { No Appeal } \\
\text { Preliminary }= \\
\text { Final }\end{array}$ & $\begin{array}{c}\text { Appeal } \\
\text { Preliminary }\end{array}$ & $\begin{array}{c}\text { Appeal } \\
\text { Final }\end{array}$ \\
\hline Mean & 0.885127 & 0.882471 & 0.883042 & 0.945017 & 0.866078 \\
\hline Median & 0.864014 & 0.862995 & 0.863397 & 0.886986 & 0.853143 \\
\hline Weighted Mean & 0.871828 & 0.865139 & 0.866635 & 0.853143 & 0.847235 \\
\hline $\begin{array}{l}\text { Coefficient of } \\
\text { Dispersion }\end{array}$ & 9.453388 & 9.197727 & 9.194569 & 16.472017 & 9.143446 \\
\hline $\begin{array}{l}\text { Price Related } \\
\text { Differential }\end{array}$ & 1.015255 & 1.020034 & 1.018932 & 1.011834 & 1.022241 \\
\hline Number of Ratios & 1486 & 1486 & 1436 & 50 & 50 \\
\hline
\end{tabular}

Summary of Duval County Appeals Analyses

An examination of the Decision to Appeal data revealed that appealed parcels

occurred more frequently in areas with older properties, within census tracts with a lower occurrence of qualified sales, and areas with a higher median income. Many variables were negligible in terms of the difference between the appealed and non-appealed groups. Total living area, education, median home values were all similar and consistent over the study period for single-family properties. Appealed parcels did exhibit a greater 
concentration of areas with a higher concentration of black residents when compared to non-appealed properties.

Prior to performing the Firth logit regression, the Decision to Appel Model predicted certain outcomes associated with the relationship between a single-family property owner's decision to appeal, and various variables related to the structure of the property, market activity, assessment practices, and neighborhood demographics. These assumptions were based upon the prior empirical research presented in Chapter Three (see Table 3).

The Decision to Appeal Model indicated a number of the independent variables were statistically significant and consistent with the model's hypotheses. The coefficients on the market value and age were positive and statistically significant $(\mathrm{p}<0.001)$, indicating that more older and more expensive properties were more likely to be appealed. The exemption variable was significantly negative for all years. $(p<0.001)$, indicating properties with homestead exemptions were less likely to be appealed. Group Five properties exhibited a positive and statistically significant $(\mathrm{p}<0.001)$ relationship with the decision to appeal. In addition, the variable representing the percentage change in market value from the previous year was positive, indicating that large increases in market value may have been an impetus for appealing a property. In addition, the sales per tract indicated a negative relationship, which suggests that the greater number of sales a given census tract resulted in fewer appeals. The remaining variables provided mixed results, which did not support the stated hypotheses.

The Duval County Value Change Model indicated a few consistent and statistically significant relationships between the dependent and independent variables. 
For all years, the total living area coefficient is significantly negative $(\mathrm{p}<0.001)$. This suggests that, all else being equal, the percentage appeals adjustment decreases as a property’s total building area increases. In addition, the coefficient for the preliminary just value or market value is significantly positive for all years $(\mathrm{p}<0.001)$. This suggests that percentage appeals adjustments are larger for homes that are more expensive. Lastly, the exemption coefficient is significantly negative $(\mathrm{p}<0.001)$ during the study period. This suggests that the percentage change in market value is less if the property has a homestead exemption.

The coefficient for the age of the building is significantly positive for 2010 and $2012(\mathrm{p}<0.001)$, but only marginally significant for $2011(\mathrm{p}=.381)$. This suggests that the percentage appeals adjustments are larger for older homes. The coefficients for the percentage change in market value are positive for all three years, which suggests that the change in the market value year-over-year is directly related to the percentage change in market value achieved at the value adjustment board.

Lastly, in terms of assessment uniformity, the sales ratio studies indicated that Duval County’s assessment review and appeal process improved the assessment uniformity of single-family properties in terms of horizontal and vertical equity. For every year of the study, the appealed properties exhibited CODs higher than the nonappealed parcels. After the appeal process was completed, the appealed properties exhibited a lower COD. However, the appealed COD's did not approach the COD of non-appealed parcels. The PRD indicated proportional assessments for all years of the study period. In some instances, the appeal process improved upon already uniform assessment statistics. 


\section{CHAPTER VIII}

\section{FINDINGS, DISCUSSION, AND CONCLUSION}

\section{$\underline{\text { Structure and Overview }}$}

This section summarizes the results of the Broward and Duval County singlefamily property appeals analyses. The section begins with a review and comparison of the property owner survey results. Next, the Decision to Appeal Model, Value Change Model, and the assessment uniformity indicators for the two counties are presented and examined. The presentation then moves to a brief discussion of the possible explanations and implications of the findings. The final section culminates the dissertation with concluding comments and suggestions for further research. For ease of presentation, summary tables from each stage of analysis, the decision to appeal, appeal value change, and assessment uniformity are first presented in Tables 61, 62, 63, and 64.

\section{Table 61}

\section{Summary of Decision to Appeal Findings}

\begin{tabular}{|c|c|c|c|c|c|c|c|c|}
\hline \multirow[t]{2}{*}{ Category } & \multirow[t]{2}{*}{ Variable Name } & \multirow[t]{2}{*}{$\begin{array}{l}\text { Expected } \\
\text { Sign } \\
\end{array}$} & \multicolumn{3}{|c|}{$\begin{array}{l}\text { Broward } \\
\text { County }\end{array}$} & \multicolumn{3}{|c|}{$\begin{array}{l}\text { Duval } \\
\text { County }\end{array}$} \\
\hline & & & 2010 & 2011 & 2012 & 2010 & 2011 & 2012 \\
\hline \multirow{2}{*}{$\begin{array}{l}\text { Structural } \\
\text { Characteristics }\end{array}$} & Log Total Living Area & + & $-* * *$ & - & - & $-* * *$ & $-* * *$ & $-* *$ \\
\hline & Age of Building & + & $-* * *$ & + & -** & $+* * *$ & $+* * *$ & $+* * *$ \\
\hline \multirow[t]{2}{*}{ Market Activity } & Recent Sale of Property & - & $+* * *$ & - & -*** & $-* * *$ & $-* * *$ & - \\
\hline & Sales Per Tract & - & $+*$ & $+* * *$ & - & $-* * *$ & $-* * *$ & $-* * *$ \\
\hline \multirow{4}{*}{$\begin{array}{l}\text { Assessment } \\
\text { Characteristics }\end{array}$} & Log Preliminary Market Value & + & $+* * *$ & $+* * *$ & $+* * *$ & $+* * *$ & $+* * *$ & $+* * *$ \\
\hline & \% Change in Market Value & - & - & + & $-* * *$ & $+* * *$ & $+* * *$ & $+* * *$ \\
\hline & Group Five & + & $+* * *$ & $+* * *$ & $+* * *$ & $+* * *$ & $+* * *$ & $+* * *$ \\
\hline & Exempt & - & -*** & $-* * *$ & _*** & $-* * *$ & -*** & _*** \\
\hline \multirow{6}{*}{$\begin{array}{l}\text { Neighborhood } \\
\text { Economic and } \\
\text { Demographic } \\
\text { Characteristics } \\
\text { Category }\end{array}$} & Log Median Income Per Tract & + & $-* * *$ & - & - & - & $+*$ & $+* *$ \\
\hline & $\begin{array}{l}\text { Log Med Home Value Per } \\
\text { Tract }\end{array}$ & + & $+* * *$ & $+* * *$ & $+*$ & + & $-* * *$ & -** \\
\hline & Percent of Tract Black & - & $+* * *$ & $+* * *$ & $+* * *$ & $+* * *$ & + & $+*$ \\
\hline & Percent of Tract White & + & $+* * *$ & $+* * *$ & $+* * *$ & $+* *$ & + & + \\
\hline & Percent without HS degree & - & $+* * *$ & $+* * *$ & $+* * *$ & $+* * *$ & $+* * *$ & + \\
\hline & $\begin{array}{l}\text { Percent w/at least Bachelor } \\
\text { Degree }\end{array}$ & + & $-* *$ & - & _*** & $-*$ & + & - \\
\hline
\end{tabular}




\section{Table 62}

Summary of Value Change Findings

\begin{tabular}{|c|c|c|c|c|c|c|c|c|}
\hline \multirow[t]{2}{*}{ Category } & \multirow[t]{2}{*}{ Variable Name } & \multirow[t]{2}{*}{$\begin{array}{l}\text { Expected } \\
\text { Sign } \\
\end{array}$} & \multicolumn{3}{|c|}{$\begin{array}{l}\text { Broward } \\
\text { County }\end{array}$} & \multicolumn{3}{|c|}{$\begin{array}{l}\text { Duval } \\
\text { County }\end{array}$} \\
\hline & & & 2010 & 2011 & 2012 & 2010 & 2011 & 2012 \\
\hline \multirow{5}{*}{$\begin{array}{l}\text { Structural } \\
\text { Characteristics }\end{array}$} & Above Average Quality & & - & + & - & $-* *$ & + & - \\
\hline & Average Quality & & - & + & + & $-* * *$ & + & - \\
\hline & Below Average Quality & & $\mathrm{n} / \mathrm{a}$ & $\mathrm{n} / \mathrm{a}$ & $\mathrm{n} / \mathrm{a}$ & $\mathrm{n} / \mathrm{a}$ & $\mathrm{n} / \mathrm{a}$ & $\mathrm{n} / \mathrm{a}$ \\
\hline & Log Total Living Area & + & $-* * *$ & $-* * *$ & + & $-* * *$ & $-* * *$ & $-* * *$ \\
\hline & Age of Building & + & - & $-* * *$ & $+* *$ & $+* * *$ & + & $+* * *$ \\
\hline \multirow[t]{2}{*}{ Market Activity } & Recent Sale of Property & - & $-* * *$ & + & + & - & - & $-* * *$ \\
\hline & Sales Per Tract & - & $-* * *$ & $-* * *$ & - & - & - & - \\
\hline \multirow{4}{*}{$\begin{array}{l}\text { Assessment } \\
\text { Characteristics }\end{array}$} & Log Preliminary Market Value & + & $+* * *$ & $+* * *$ & $+* *$ & $+* * *$ & $+* * *$ & $+* * *$ \\
\hline & \% Change in Market Value & - & - & $-* * *$ & $-* * *$ & $+* * *$ & $+*$ & $+* * *$ \\
\hline & Group Five & + & - & $+* * *$ & - & + & $+* *$ & + \\
\hline & Exempt & - & - & $-* * *$ & - & - & - & - \\
\hline \multirow{8}{*}{$\begin{array}{l}\text { Neighborhood } \\
\text { Economic and } \\
\text { Demographic } \\
\text { Characteristics } \\
\text { Category }\end{array}$} & Log Median Income Per Tract & + & $+* * *$ & $+* * *$ & - & + & - & + \\
\hline & Log Med Home Value Per Tract & + & + & $-* * *$ & - & + & - & - \\
\hline & Percent Black & - & - & $+*$ & - & $+^{*}$ & - & - \\
\hline & Percent White & + & - & + & - & $+* *$ & - & $-* *$ \\
\hline & Percent without HS degree & - & + & + & + & $+*$ & + & + \\
\hline & $\begin{array}{l}\text { Percent w/at least Bachelor } \\
\text { Degree }\end{array}$ & + & - & + & $+* *$ & $-* * *$ & + & + \\
\hline & Agent & $?$ & $+* * *$ & -*** & -*** & - & - & $-* * *$ \\
\hline & Mills Inverse Ratio & $?$ & $+* * *$ & $+* * *$ & - & $+*$ & - & $+* *$ \\
\hline
\end{tabular}

Table 63

Summary of Broward County Uniformity Indicators

\begin{tabular}{|c|c|c|c|c|c|c|c|c|c|}
\hline & \multicolumn{9}{|c|}{ Broward County } \\
\hline & \multicolumn{3}{|c|}{2010} & \multicolumn{3}{|c|}{2011} & \multicolumn{3}{|c|}{2012} \\
\hline & $\begin{array}{c}\text { No } \\
\text { Appeal }\end{array}$ & $\begin{array}{l}\text { Appeal } \\
\text { Prelim }\end{array}$ & $\begin{array}{c}\text { Appeal } \\
\text { Final }\end{array}$ & $\begin{array}{c}\text { No } \\
\text { Appeal }\end{array}$ & $\begin{array}{l}\text { Appeal } \\
\text { Prelim }\end{array}$ & $\begin{array}{c}\text { Appeal } \\
\text { Final }\end{array}$ & $\begin{array}{c}\text { No } \\
\text { Appeal }\end{array}$ & $\begin{array}{l}\text { Appeal } \\
\text { Prelim }\end{array}$ & $\begin{array}{c}\text { Appeal } \\
\text { Final }\end{array}$ \\
\hline Mean & 0.88624 & 0.93383 & 0.89427 & 0.89747 & 0.94869 & 0.93698 & 0.90486 & 0.94675 & 0.93708 \\
\hline Median & 0.87048 & 0.89909 & 0.86704 & 0.88069 & 0.91168 & 0.90157 & 0.90387 & 0.93787 & 0.92895 \\
\hline $\begin{array}{l}\text { Weighted } \\
\text { Mean }\end{array}$ & 0.86406 & 0.89646 & 0.86594 & 0.87951 & 0.92114 & 0.90123 & 0.89278 & 0.93308 & 0.91679 \\
\hline $\begin{array}{l}\text { Coefficient } \\
\text { of } \\
\text { Dispersion }\end{array}$ & 7.51094 & 10.07129 & 8.63038 & 8.40227 & 11.02157 & 10.72924 & 8.01383 & 7.85367 & 7.52094 \\
\hline $\begin{array}{l}\text { Price } \\
\text { Related } \\
\text { Differential }\end{array}$ & 1.02567 & 1.04168 & 1.03271 & 1.02041 & 1.02990 & 1.03966 & 1.01353 & 1.01464 & 1.02213 \\
\hline
\end{tabular}


Table 64

Summary of Duval County Uniformity Indicators

\begin{tabular}{|c|c|c|c|c|c|c|c|c|c|}
\hline & \multicolumn{9}{|c|}{ Duval County } \\
\hline & \multicolumn{3}{|c|}{2010} & \multicolumn{3}{|c|}{2011} & \multicolumn{3}{|c|}{2012} \\
\hline & $\begin{array}{c}\text { No } \\
\text { Appeal }\end{array}$ & $\begin{array}{l}\text { Appeal } \\
\text { Prelim }\end{array}$ & $\begin{array}{c}\text { Appeal } \\
\text { Final }\end{array}$ & $\begin{array}{c}\text { No } \\
\text { Appeal }\end{array}$ & $\begin{array}{l}\text { Appeal } \\
\text { Prelim }\end{array}$ & $\begin{array}{c}\text { Appeal } \\
\text { Final }\end{array}$ & $\begin{array}{c}\text { No } \\
\text { Appeal }\end{array}$ & $\begin{array}{c}\text { Appeal } \\
\text { Prelim }\end{array}$ & $\begin{array}{c}\text { Appeal } \\
\text { Final }\end{array}$ \\
\hline Mean & 0.88052 & 0.98843 & 0.88084 & 0.86476 & 1.01796 & 0.87959 & 0.88304 & 0.94501 & 0.86607 \\
\hline Median & 0.8806 & 0.96848 & 0.89539 & 0.85644 & 1.06249 & 0.86238 & 0.86339 & 0.88698 & 0.85314 \\
\hline $\begin{array}{l}\text { Weighted } \\
\text { Mean }\end{array}$ & 0.86842 & 0.96257 & 0.87459 & 0.85655 & 0.97915 & 0.85667 & 0.86663 & 0.85314 & 0.84723 \\
\hline $\begin{array}{l}\text { Coefficient } \\
\text { of } \\
\text { Dispersion }\end{array}$ & 7.95107 & 11.05231 & 9.44814 & 8.33366 & 10.88795 & 9.54739 & 9.19456 & 16.47201 & 9.14344 \\
\hline \begin{tabular}{|l|} 
Price \\
Related \\
Differential \\
\end{tabular} & 1.01393 & 1.02686 & 1.00714 & 1.00958 & 1.03964 & 1.02675 & 1.01893 & 1.01183 & 1.02224 \\
\hline
\end{tabular}

$\underline{\text { Survey Results }}$

All of the previous empirical research related to the study of property tax assessment review and appeal systems utilized the analyses of available data sets as the primary research methodology. With improvements in information technology and the implementation of public information access laws, quantitative data related to property tax appeals has become increasingly available and relatively inexpensive to access for researchers interested in the subject of property tax assessment uniformity.

This study attempted to enhance the current property tax administration literature by utilizing a mixed-method design, which included the use of a custom-designed survey instrument distributed directly to single-family property owners. The survey would then be used in conjunction with the traditional analysis of available property tax appeal data to provide a richer perspective of the property tax appeal process.

The expectation concerning the survey was to include variables related to singlefamily property owners’ opinions of property taxes and government services with 
structural, assessment, market, and demographic variables to explain and predict property owners' participation in the assessment review and appeal process. Unfortunately, the response rates for both Broward and Duval Counties were too low, limiting the statistical significance of the data and consequently the ability to utilize inferential statistics in the study. However, the survey data remained useful by providing context related to property owners' participation in the appeals process, opinions concerning property taxes, and opinions concerning government services.

Surveys from both counties revealed that $21 \%-25 \%$ of the respondents had previously participated in the informal appeals process, where in, the property owner contacted their respective property appraiser to question the assessment of their property. In some instances, property owners experienced an increase in their property's market value.

A much lower percentage of respondents reported moving beyond the informal process and actually filing a formal petition with their county's Value Adjustment Board. Remarkably, 58.9\% of Broward respondents and 37.5\% of Duval respondents indicated they were unaware that properties could be appealed on a yearly basis, despite efforts of government officials to make property owners aware of the process through mailings and notifications on their respective websites.

When questioned about attitudes concerning the property tax itself, the responses were largely positive. Single-family property owners in both counties indicated that they preferred the property tax when compared to the prospect of a state income tax. In addition, property owners felt their property taxes were fair when compared to their 
neighbors. However, the property owners did indicate that the property tax represented a significant household budget concern in both counties.

Overall, the survey data suggests that property owners were more concerned with government service and the conduct of government officials than the property tax itself. Respondents in both counties indicated that the revenues derived from the property tax were not utilized in an efficient manner, county government officials did not act in an ethical manner that officials were influenced by special interests, and did not consider the needs of local property owners.

\section{Decision to Appeal}

Previous research has examined a property owner's decision to appeal a property tax assessment as a dependent binary variable wherein the decision to appeal is equal to one and the decision to appeal is zero (Weber \& McMillen, 2010; Plummer 2014). Despite the obvious motivation, reducing the value of the property and therefore reducing the tax burden, this study sought to discover additional variables that spurred participation in the property tax appeals process. In the Decision to Appeal Model, the explanatory variables are a vector of variables that reflect the characteristics of property owners in the area, the structural characteristics of their respective properties, data related to the local real estate market, and local assessment practices.

It was previously postulated that the variable interactions within the Decision to Appeal Model would reveal patterns allowing the researcher to identify who utilizes assessment review and appeal system, and ascertain their motivations for participation. However, the results of the Decision to Appeal Model produced varied results, limiting the ability to predict and interpret the interaction of the variables. 
In all, fifteen variables were utilized to reflect independent variables that may have an effect on a property owner's decision to appeal a property tax assessment. Of the fifteen variables, only three variables exhibited a statistically significant and consistent relationship with the decision to appeal, in both counties, over the three-year period (See Table 61). The coefficients on the preliminary just or market values were positive and statistically significant $(p<0.001)$, indicating that more expensive properties were more likely to be appealed. In addition, the exemption variable was significantly negative for all years ( $\mathrm{p}<0.001$ ), indicating properties with homestead exemptions were less likely to be appealed. Finally, Group Five properties exhibited a positive and statistically significant $(\mathrm{p}<0.001)$, relationship with the decision to appeal.

Other variables exhibited statistically significant and statistically significant relationships but were limited to a particular county. For example in Broward County, the variables indicating the percentage of residents without a high school education and the racial composition of a given census tract were all indicated a positive coefficient and were statistically significant $(\mathrm{p}<0.001)$.

Meanwhile, in Duval County, the coefficient for the age of the property was positive and statistically significant $(\mathrm{p}<.001)$, indicating that older properties were more likely to be appealed. In addition, the coefficient for sales per tract were negative and statistically significant $(\mathrm{p}<0.001)$, indicating that appeals were more likely come from areas with less market activity. Lastly, the coefficients for percent change in value from the previous year were positive; indicating that a greater change in the appraiser's opinion of market value prompted appeals activity. 
In addition to the Decision to Appeal regression analyses, choropleth maps were created to observe patterns of single-family appeals activity in both counties (See Figures 4, 5 and 6). The maps of Broward County single-family parcels appealed by census tract revealed that appealed parcels were largely clustered around the western portions (including municipalities such as Parkland, Weston, and Miramar) and the eastern portions (Fort Lauderdale, Lauderdale by the Seas, and portions of the intra-coastal waterway) of the county. The appeals activity effectively mimicked a donut shape in which the interior portions of the county were appealed less frequently. While the total number of single-family parcel appeals declined over the study period, the concentration of the appealed properties appeared to remain in the same areas of the county.

In Duval County, the thematic maps of single-family parcel appeals per tract revealed that appealed parcels were clustered around the southern portions (particularly along the St. Johns River) and the eastern portions (Atlantic Beach, Neptune Beach, Jacksonville Beach, and areas along the intra-coastal) of the county (See Figures 10, 11, 12). Similar to Broward County, the total number of single-family appeals declined over the study period. However, unlike Broward, the location of appealed properties appeared to move westward towards the center of the county over time.

\section{Value Change}

In addition to the Decision to Appeal Model, the changes in the market value of appealed parcels were examined. Earlier studies examined the output of the assessment review and appeals process in one of two ways. The first approach is to examine the probability of a successful appeal (Weber \& McMillen, 2010). Here, appeal success is framed as a binary output, in which a reduction in value is granted or denied. The second 
approach is to examine appeal success in terms of the change in market value for an appealed property (Plummer, 2010). Under this approach, the change is market value serves as a continuous dependent variable.

This study employed the change in market value approach or Value Change Model but utilized a slightly different technique in the development of the dependent variable. An examination of the available appeal data revealed the output of Florida's assessment review and appeals process can be characterized under several different categories: granted, denied, withdrawn, resolved, and no show. In light of the various categories associated with the outputs of the VAB process, the Value Change Model included any adjustment made to the just or market value of properties that were appealed. The intent was to account for all reductions in market value for properties that were denied a reduction, or withdrawn from VAB consideration.

While the dependent variable differed slightly from the previous studies, in this instance, the independent variables were very similar. Again the same fifteen variables from the Decision to Appeal were included the Value Change Model. In addition, three new variables were included for consideration; the quality of construction, the use of professional representation, and the inverse Mills ratio (to control for endogeneity).

The results of the value change analysis for Broward County were largely mixed (See Table 62). Many of the estimations were consistent for the 2010 and 2011 tax years, but the 2012 tax year often produced conflicting results. For example the total living area exhibited a negative coefficient and was statistically significant $(\mathrm{p}<0.001)$. However, the same variable exhibited a positive coefficient and was deemed statistically insignificant for the 2012 tax year $(p=.580)$. The coefficients for sales per tract and the log of the 
preliminary just value produced did produce consistent and statistically significant results during the study period. The variable agent indicated that professional representation resulted in a percentage decrease in the market value for 2010, but was less effective, as compared to homeowners that represented themselves, in obtaining a reduction for the 2011 and 2012 tax years.

Unlike the Broward County data, the Duval County Value Change Model indicated quite a few consistent and statistically significant relationships between the dependent and independent variables (See Table 62). For all years, the total living area coefficient is significantly negative $(\mathrm{p}<0.001)$. This suggests that, all else being equal, the percentage appeals adjustment decreases as a property's total building area increases. In addition, the coefficient for the preliminary just value or market value is significantly positive for all years $(\mathrm{p}<0.001)$. This suggests that percentage appeals adjustments are larger for homes that are more expensive. Lastly, the exemption coefficient is significantly negative $(\mathrm{p}<0.001)$ during the entire study period, suggesting that the percentage change in market value is less if the property has a homestead exemption.

In addition to the Heckman two-stage regression analyses for the change in market value of appealed properties, thematic maps were created to indicate the percent of successful single-family appeals per census tract. The Broward County maps indicated that the squeakiest wheels did not necessarily get the proverbial grease. Census tracts located in the center of the county received a greater percentage of reductions (Figures 7, 8, 9), as opposed to areas along the perimeter of the county which exhibited a higher appeal rate. 
For Duval County, the Value Change Maps indicated that a majority of the singlefamily properties, which filed an appeal in Duval County, received some type of reduction in market value over the three-year period (Figures 13, 14, 15). The higher concentrations of reductions per census tract, took place in the center of the county, while the lower concentrations of reductions per census tract took place in the southeast portion of the county.

\section{Assessment Uniformity}

The industry standard by which to judge the uniformity of property tax assessment activities is to compare the assessments derived by the property appraiser to the actual sales price of a given property. In order to determine the effect of singlefamily appeals activity on the assessment uniformity of single-family properties located in Broward and Duval Counties, separate sales-ratio studies were conducted for each year of the study period. The ratio studies were conducted using the IAAO's Standard on Ratio Studies and the State of Florida's statutory requirements for property tax assessments. The ratio study analyses indicated that the initial assessments of singlefamily properties were in line with the level of assessment standards (85\%-100\%), measures of horizontal equity (COD between 8 and 9), and measures of vertical equity (PRD between 1.00-1.02) (See Table 3). However, when the data was stratified by county, year, and appealed versus non-appealed status, systematic differences in assessment uniformity were discovered. At the conclusion of the ratio study analyses it was determined that the appeal process largely improved aspects of assessment uniformity in both counties. 
In Broward County, the sales ratio studies indicated that Broward County's assessment review and appeal process improved the assessment uniformity of singlefamily properties in terms of horizontal equity but slightly increased regressivity in terms of vertical equity (See Table 63). For every year of the study, the appealed properties exhibited CODs higher than the non-appealed parcels. After the appeal process was completed, the appealed properties exhibited a lower COD. However, the appealed COD's did not approach the COD of non-appealed parcels. Conversely, the examination of vertical equity indicated that appealed parcels exhibited an increase in regressivity, after the appeals process was completed. In other words, the higher-valued appealed properties exhibited lower assessment-to-sale ratios as compared to lower-valued appealed properties.

The sales ratio studies also indicated that Duval County's assessment review and appeal process improved the assessment uniformity of single-family properties in terms of horizontal equity and vertical equity. For every year of the study, the appealed properties exhibited CODs higher than the non-appealed parcels (See Table 64). After the appeal process was completed, the appealed properties exhibited a lower COD. However, the appealed COD's did not approach the COD of non-appealed parcels. The PRD indicated proportional assessments for all years of the study period. In some instances, the Duval County property tax appeal process improved upon already uniform assessment statistics. 


\section{$\underline{\text { Conclusion }}$}

Property tax assessment review and appeals systems are present, in some form, in every state of the Union. As a result of its decentralized beginnings, these various systems have developed distinct methods for accomplishing common goals. As previously mentioned, media outlets across the country have chronicled an increase in the occurrence of property owners participating in the property tax assessment review and appeal process. Considering the abundance of these institutions, the record number of property owners participating in the process, and the paucity of empirical research related to property tax assessment review and appeal systems, this study presented an excellent opportunity to contribute to the property tax administration literature.

The objectives of the dissertation were to gain a better understanding of who participated in the property tax appeal process and their motivations for participation; to determine who was successful and why; and to determine whether the outcomes of assessment review and appeal process were proportional, regressive, or progressive. To a limited extent, this dissertation accomplished those goals. Attempting to predict the factors that motivated participation in the assessment review and appeal system and the degree of property tax appeal success, proved to be a challenging academic exercise in which the study yielded inconsistent results.

Anecdotal evidence has suggested that wealthy property owners and unruly property tax agents have commandeered the property tax assessment review and appeal process (Kestin \& Maines, 2010; Christensen, 2014; Smiley, 2014). However, the empirical evidence from both counties provided a more muddled portrayal of the property tax appeal process. 
The empirical evidence suggests that appeals are more likely to come from properties with higher assessed values and from census tracts with high median values in both counties. Furthermore, the thematic maps of single-family appeals activity in both counties suggest that appealed properties were more prevalent in the coastal portions (areas traditionally associated with higher property values). These occurrences suggest that more affluent (or at least property rich) property owners are more likely to utilize the property tax assessment review and appeal system, as the anecdotal evidence suggests.

However, in terms of the use of professional representatives at the VAB hearings, the evidence is conflicting. The Broward County appeals data indicated a much higher percentage of properties represented by property tax agents over the study period (64\%89\%) as compared to Duval County (15\%-23\%). Interestingly, regardless of the county, owners who represented themselves were more likely to receive a reduction in market value than property owners who utilized a professional representative.

When it came to examining the outputs and outcomes of the two counties' value adjustment boards, the data again provided mixed results. While the majority of appeals came from areas along the coast and western portions of Broward County data, the greater number of reductions (single-family properties per census tract) came from the interior portions of the county, which on average have an older housing inventory, lower median home values, and lower median incomes. This suggests that in Broward County, the squeakiest and shiniest wheels did not necessarily get the grease.

The Duval County data indicates a similar appeal activity pattern in terms of geography, with the majority of appeals taking place along the coastal areas. However, 
as opposed to Broward County, market value changes obtained because of appeal participation, took place in all areas of Duval County.

The most useful aspect of this empirical exercise were the findings of the assessment uniformity analyses. The results indicated that the appeals mechanisms in both counties improved assessment uniformity over the study period. On average, appealed properties exhibited greater indications of horizontal and vertical inequities, as compared to non-appealed properties. However, after the appeal process was completed, these indicators of horizontal and vertical were largely improved, albeit the indicators were not equivalent to the uniformity indicators of non-appealed properties.

The inconsistencies in this study's findings serves to highlight the obstacles in generalizing this type of research to different geographic areas, even for areas located within the same state. Despite the challenges associated with examining property tax appeal systems, the study was able to confirm that the assessment review and appeal process does serve to improve property tax uniformity among single-family properties.

\section{$\underline{\text { Recommendations }}$}

Despite the negative perceptions often associated with the property tax, history has shown that the tax will likely continue to serve as a major revenue source for local governments. However, policy reforms throughout the United States simultaneously indicate that political pressures may continue to place stricter restrictions on how the property tax is utilized and administered (Haveman, 2008). If recent news headlines are any indicator, property tax assessment appeal and review systems may soon be subject to these reform movements. In light of the new and ever-changing realities surrounding the 
property tax and its administration, policy makers and administrators have to continue to ensure citizens that the property tax is accurate, fair, and efficient.

In the case of Florida, the evidence suggests (albeit, contextually) that singlefamily property owners are supportive of the property tax, at least when compared to the prospects of a state income tax. Further evidence suggests that many of the factors that influence the decision to appeal a property may be out of the immediate control of local government officials, and as such, may have little impact on the day-to-day operations of local property tax appraisers and the entities involved with property tax assessment review and appeal process.

However, these agencies would be well served to better educate their constituents about the property tax appeal process. First, officials should work to better inform citizens of the existence of the property tax appeal process. Despite, the current efforts of local property appraisers (referring to the VAB in TRIM documents and websites), a large portion of survey respondents indicated that they were unaware of the appeals process. Secondly, in the same vein, officials should take care to examine the outputs and share the outcomes of the property tax appeal process with all stakeholders in their respective jurisdictions. The study indicated that in terms of single-family properties, the assessment review and appeal process improved assessment uniformity among like properties and that the process was not biased in favor of properties represented by property tax agents.

\section{Opportunities for Further Study}

This study marks the beginning of a broader research agenda involving elements of property tax policy and administration. Future research prospects look to extend the 
scope of the research questions presented in this study. The extension of this research includes examining other residential property types including condominiums and townhomes, and examining various commercial properties such as offices, retail, multifamily and warehouse space.

Prospective research projects are not limited to various property types, opportunities to expand exist temporally and spatially, as well. Future studies could include longer study periods to account for various macroeconomic factors including boom and bust real estate cycles. Research could also expand geographically through the examination of large metropolitan regions, states, and even international property tax systems. Metropolitan statistical areas with multiple county appeal mechanisms or states with more centralized appeal mechanisms are candidates for examination. Many countries located in Africa and Eastern Europe have adopted fiscal decentralization policies, which have included the adoption of the property tax as a revenue-generating source (Bell \& Bowman, 2008; Sennoga, Sjoquist, \& Wallace, 2008). 


\section{LIST OF REFERENCES}

Advisory Commission on Intergovernmental Relations. (1963). The Role of the States in Strengthening the Property Tax, Vol.2. Washington, DC: Government Printing Office.

Advisory Commission on Intergovernmental Relations. (1974). Federal-State-Local Finances: Significant Features of Fiscal Federalism. Washington, DC: Government Printing Office.

Advisory Commission on Intergovernmental Relations. (1974). Property Tax Circuit Breakers: Current Status and Policy Issues. Washington, DC: Government Printing Office.

Advisory Commission on Intergovernmental Relations. (1974). The Property Tax in a Changing Environment; Select State Studies. Washington, DC: Government Printing Office.

Advisory Commission on Intergovernmental Relations. (1975). State Legislative Program Part 3. Washington, DC: Government Printing Office.

Advisory Commission on Intergovernmental Relations. (1995). Tax and Expenditure Limits on Local Governments. Washington, DC: Government Printing Office.

Advisory Commission on Intergovernmental Relations. (1997). Significant Features of Fiscal Federalism, 1995: Volume 2 - Revenues and Expenditures. Washington, DC: Government Printing Office.

Allen, M.T., \& Dare, W.H. (2002). Identifying Determinants of Horizontal Property Tax Inequity: Evidence from Florida. Journal of Real Estate Research, 24, 153-163.

Bell, M.E., \& Bowman, J.H. (2008). Extending Property Taxation into Previously Untaxed Areas; South African Townships and Tribal Areas. In R. Bahl, J. Martinez-Vasquez, \& J. Youngman (Eds.) Making the Property Tax Work: Experiences in Developing and Transitional Countries. Cambridge, MA. Lincoln Institute of Land Policy.

Bowman, J.H., \& Butcher, W.A. (1986). Institutional Remedies and the Uniform Assessment of Property: An Update and Extension. National Tax Journal, 39, 157-169.

Bowman, J.H., \& Mikesell, J.L. (1978). Uniform Assessment of Property: Returns from Institutional Remedies. National Tax Journal, 31, 137-152.

Bowman, J.H., \& Mikesell, J.L. (1990). Assessment Uniformity: The Standard on Its Attainment. Property Tax Journal, 9, 219-233. 
Blocksidge, C. \& Downing, R.H. (1989). The Effect of the Appeal Process on Property Tax Equity. $55^{\text {th }}$ International Conference on Assessment Administration, 127142.

Christensen, D. (2014, Jun 18). Property tax appeals process rigged, audit finds - Boards that consider property tax appeals from the public lack independence and are stacked against property owners, an audit has found. The Miami Herald. Retrieved from http://infoweb.newsbank.com/resources/doc/nb/news/14E8B9D2D5B2D710?p=A WNB

Coffman, J.F. (1989). Alternatives in Property Tax System Design. Property Tax Journal, 8, 235-248.

Converse, J.M. \& Presser, S. (1986). Survey Questions Handcrafting the Standardized Questionnaire. Sage University Paper series on Quantitative Applications in Social Sciences, series no. 07-063). Thousand Oaks, CA: Sage Publications.

Cornia, G.C. \& Walters, L.C. (2005). Full Disclosure: Unanticipated Improvements in Property Tax Uniformity. Public Budgeting \& Finance, 25, 106-123.

Doerner, W.M. (2012). The Effects of House Prices on Taxation and Property Valuation. Retrieved from Dissertations and Theses database. (UMI No. 3539546)

Doerner, W.M. \& Ihlanfeldt, K. (2014). An Empirical Analysis of the Property Tax Appeals Process. Journal of Property Tax Assessment \& Administration, 11.4, 534

Doerner, W.M. \& Ihlanfeldt, K. (2015). The Role of Representative Agents in the Property Tax Appeals Process. National Tax Journal, 68.1, 59-92.

Downing, R.H. \& Blocksidge, C. (1990). The Appeal Process and Residential Property Tax Regression. $56^{\text {th }}$ International Conference on Assessment Administration, 201-212.

Eckert, J.K., Gloudemans, R.J., and Almy R.R. eds. Property Appraisal and Assessment Administration. Chicago: International Association of Assessing Officers, 1990.

Eom, T.H. (2008). A Comprehensive Model of Determinants of Property Tax Assessment Quality: Evidence in New York State. Public Budgeting \& Finance, 28, 58-81

Fisher, G.W. (1989). Property Taxation and Local Government: Four Hypotheses. Property Tax Journal, 8, 113-128.

Fisher, G.W. (1997). Some Lessons from the History of the Property Tax. Assessment Journal, 4, 40-46. 
Firoozi, F., Hollas, D.R., Rutherford, R.C., \& Thomson, T.A. (2006). Property Assessments and Information Asymmetry in Residential Real Estate. Journal of Real Estate Research, 28, 275-291.

Firth, D. (1993). Bias Reduction of Maximum Likelihood Estimates. Biometrika, 80, 27-38.

Florida Department of Revenue. (2002). Property Tax Rules Chapters 12D-1 through 12D-51, and 12-9 Florida Administrative Code. Tallahassee, FL: Government Printing Office.

Florida Department of Revenue. (2002). The Florida Real Property Appraisal Guidelines. Tallahassee, FL: Government Printing Office.

Florida Department of Revenue. (2013). Broward County Property Tax Overview 2012. Tallahassee, FL: Government Printing Office.

Florida Department of Revenue. (2013). Duval County Property Tax Overview 2012. Tallahassee, FL: Government Printing Office.

Fowler, F.J. (2013). Survey Research Methods. (Fifth Edition). Thousand Oaks, CA: Sage Publishers.

Geraci, V.J., \& Plourde, J.L. (1976). The Determinants of Uniform Property Tax Assessment. Assessor's Journal, 11, 231-251.

Green, N. (2013, Sep 5). Dade property appraiser changes appeal process. The Miami Herald. Retrieved from http://infoweb.newsbank.com/resources/doc/nb/news/148A768DA38C6B08?p=A WNB

Haveman, M., \& Sexton, T.A., (2008). Property Tax Assessment Limits: Lessons from Thirty Years of Experience. Policy Focus Report. Cambridge, MA. Lincoln Institute of Land Policy.

Hale, D. (1985). The Evolution of the Property Tax: A Study of the Relation between Public Finance and Political Theory, Journal of Politics, 47, 382-404.

Harris, B.H., \& Moore, B.D., (2013). Residential Property Taxes in the United States. Research Report. Washington DC, Urban-Brookings Tax Policy Center.

Hellerstein, J.R. \& Hellerstein, W. (1988). State and Local Taxation: Cases and Materials. $5^{\text {th }}$ ed. St. Paul, MN. West Publishing.

Hissong, R.V., \& Hawley, R.F. (2012). Analyzing the Residential Property Appraisal and Outcomes to Determine if a Property Tax Revolt is Imminent. Social Science Quarterly, 93, 191-210. 
Howe, E.T. \& Reeb, D.J. (1994). An Overview of State-Published Local Government Financial Data. Public Administration Review, 5, 496-500.

Howe, E.T, \& Reeb, D.J. (1997). The Historic Evolution of State and Local Tax Systems. Social Science Quarterly, 1, 109-122.

Ihlanfeldt, K. (2004). The Use of an Econometric Model for Estimating Aggregate Levels of Property Tax Assessment within Local Jurisdictions. National Tax Journal, 57, 7-23.

International Association of Assessing Officers. (2001). Standard on Assessment Appeal. Assessment Journal, 4, 37-41.

International Association of Assessing Officers. (2010), Standard on Ratio Studies. Kansas City, MO. International Association of Assessing Officers.

International Association of Assessing Officers, (2010). Standard on Property Tax Policy. Kansas City MO. International Association of Assessing Officers.

International Association of Assessing Officers, (2011). Ratio Study Practices in the United States and Canada: Results of 2011 Survey. Journal of Property Tax Assessment and Administration, 9, 5-88.

Jackson, G. (2010, January 22). County scrambles to adjust its budget: Prison appealed value assessment, costing anticipated tax revenue. Florida Times-Union, 3.

Kestin, S. \& Maines, J. (2010, August 15) Property tax appeals on a blistering pace: More taxpayers challenge valuations but the process favors the wealthy, who win more cases. Sun-Sentinel (FL), 1A.

Lamendola, M. (2010, August 5). Town borrows \$3.75M to cover tax appeals. South Bergenite (NJ), 3.

Levy, J. (1995). Essential Microeconomics for Public Policy Analysis. Westport, CT: Praeger Publishers.

Lynn Jr., A.D. (Ed.) (1967). The Property Tax and its Administration. Wisconsin: The University of Wisconsin Press.

Malme, J. (1991). Policies and Practices That Promote Assessment Equity: Case Studies of Alternative Models, Working Paper. Cambridge, MA. Lincoln Institute of Land Policy.

Marimow, A.E. (2010, April 18). Overhaul sought for real estate tax panel D.C. finance chief says appeals are deepening city's financial woes. Washington Post, C1. 
Mazzei, P. (2014, Aug 4). Miami-Dade property appraiser: Florida should change rule that contributes to tax-collection delays. The Miami Herald. Retrieved from http://infoweb.newsbank.com/resources/doc/nb/news/14F8374805F9DC88?p=A WNB

Mazzei, P. (2014, Nov 18). Miami-Dade must reapprove budget, tax rate after state finds advertising error. The Miami Herald. Retrieved from http://infoweb.newsbank.com/resources/doc/nb/news/151B2A8B58F13160?p=A WNB

Mazzei, P. (2014, Dec 1). Ads for do-over Miami-Dade budget hearing to be published twice. The Miami Herald. Retrieved from

http://infoweb.newsbank.com/resources/doc/nb/news/151F736B85F56FB8?p=A WNB

McMillen, D.P. (2013). The Effect of Appeals on Assessment Ratio Distributions: Some Nonparametric Approaches. Real Estate Economics, 41.1, 165-191.

Miami Herald Editorial. (2011, Jun 27). New law fair to all Florida taxpayers - OUR OPINION: Property owners challenging their home assessment will have to pay part of bill upfront. The Miami Herald. Retrieved from http://infoweb.newsbank.com/resources/doc/nb/news/1382398B5581E7B8?p=A WNB

Mikesell, J.L. (1980). Property Tax Reassessment Cycles: Significance for Uniformity and Effective Rates. Public Finance Review, 8, 23-37

Mitchell, G.W. (1956). Is This Where We Came In? Proceedings of the National Tax Association, 1956, 494.

Musgrave, R.A., \& Musgrave, P.B., (1989). Public Finance in Theory and Practice. $5^{\text {th }}$ ed. New York: McGraw-Hill.

Netzer, D. (1966). Economics of the Property Tax. Washington D.C.: The Brookings Institution.

Olorunnipa, T. (2012, Mar 20). New property tax appeals process could surprise homeowners - Property owners who have appealed their tax bills have until March 31 to pay up — or their appeals will be thrown out. The Miami Herald. Retrieved from http://infoweb.newsbank.com/resources/doc/nb/news/13DA8CF8ABCED030?p= AWNB

Plummer, E. (2006). The Effect of Land Value Ratio on Property Tax Protests and the Effects of Protests on Assessment Uniformity, Working Paper. Cambridge, MA. Lincoln Institute of Land Policy. 
Plummer, E. (2014). The Effects of Property Tax Protests on the Assessment Uniformity of Residential Properties. Real Estate Economics, 42, 900-937.

Pops, G.M. (1985). An Overview of Property Assessment Review and Appeal Systems: Goals, Variables, and Issues. Property Tax Journal, 4, 105-128.

Ratcliff, R., \& Pennick, P. (1983). Property Tax Appeals and the Distribution of the Tax Burden: An Analysis of a Losing Battle in the Citizen's “Tax Revolt.” Journal of Political and Military Sociology. 11, 69-91.

Rodriguez-Taseff, L. (2013, Jul 7). Water drives South Florida's economy. The Miami Herald. Retrieved

from http://infoweb.newsbank.com/resources/doc/nb/news/1476AFEBB4D64690 ?p=AWNB

Seligman, E.R.A. (1895). Essays in Taxation. New York, NY: The McMillan Company.

Sennoga, E.B., Sjoquist, D.L., \& Wallace, S. (2008). Incidence and Economic Impacts of Property Taxes in Developing and Transitional Countries. In R. Bahl, J. Martinez-Vasquez, \& J. Youngman (Eds.) Making the Property Tax Work:

Experiences in Developing and Transitional Countries. Cambridge, MA. Lincoln Institute of Land Policy. Significant Features of the Property Tax. http://www.lincolninst.edu/subcenters/significant-features-propertytax/Report_State.aspx. Lincoln Institute of Land Policy and George Washington Institute of Public Policy. (State Summaries; accessed: 10/22/2010 1:03:57 PM)

Sirmans, G., Diskin, B., \& Friday, H. (1995). Vertical Inequity in the Taxation of Real Property. National Tax Journal, 68, 71-84.

Smiley, D. (2013, Sep 2). Miami-Dade schools: Tax collections short \$65 million. The Miami Herald. Retrieved from http://infoweb.newsbank.com/resources/doc/nb/news/14897EA1092BF620?p=A WNB

Smiley, D. (2014, Mar 20). Miami-Dade budget crunch puts tax agents under fire. The Miami Herald. Retrieved from http://infoweb.newsbank.com/resources/doc/nb/news/14CB0FE8820C6618?p=A WNB

Smiley, D. (2014, Feb 5). Carvalho: Miami-Dade Schools tax collections could fall \$60 million short - again. The Miami Herald. Retrieved from http://infoweb.newsbank.com/resources/doc/nb/news/14BCE7634B6582D0?p=A WNB

Twark, R.D., Eyerly, R.W., \& Downing, R.H. (1989). Some Insights into Understanding Assessment Uniformity Measures: Regressivity and Progressivity. Property Tax Journal, 8, 183-191. 
Veiga, C., \& Nehamas, N. (2015, Jan 14). Miami-Dade school board considers suit to recover \$40 million in tax shortfalls. The Miami Herald. Retrieved from http://infoweb.newsbank.com/resources/doc/nb/news/152DF3EB15588210?p=A WNB

Weber, R., \& McMillen, D. (2006). Ask and Ye Shall Receive? Predicting the Successful Appeal of Property Tax Assessments, Working Paper. Cambridge, MA. Lincoln Institute of Land Policy.

Weber, R., \& McMillen, D. (2010). Ask and Ye Shall Receive? Predicting the Successful Appeal of Property Tax Assessments. Public Finance Review, 38.1, 74-101.

Wilde, J.R. (2001). Property Tax Systems: Analysis of the Maine, Michigan, and Pennsylvania Assessment and Appeals Systems. Journal of Property Tax Management, 12, 73-82.

Wyland, S., (2010, March 13). Revenue to fall on property value appeals. Las Vegas Review-Journal, 5B.

Youngman, J.M. (1989). Legal Aspects of United States Property Taxation: The Federal Role in Local Taxation. Property Tax Journal, 4, 263-275.

Youngman, J.M. (1994). Introduction to Legal Issues in Property Valuation and Taxation, Assessment Journal, 2, 60-77. 
APPENDICES 


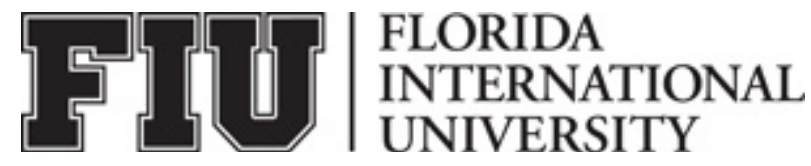

\section{INFORMATIONAL LETTER}

\section{UNDERSTANDING THE IMPACT OF THE PROPERTY TAX APPEAL PROCESS ON ASSESSMENT UNIFORMITY; PROCEDURES, STRUCTURES AND OUTCOMES}

Hello, my name is Michael Paparesta; I am a doctoral student at Florida International University. You have been chosen at random to take part in a research study about the state of Florida's property tax appeal system. The purpose of this study is to explore the motivations of property owners who choose to participate or not to participate in the property tax appeal process. It is expected that this study will benefit society by providing scholars and policymakers a better understanding of why property owners choose to appeal their property tax assessments.

Participation in this study will take approximately fifteen to thirty minutes of your time. There are no foreseeable risks in your participating in this study. Your identity will remain anonymous and your answers are confidential. Your participation in this study is voluntary, and you will not be penalized if you choose not to participate. If you agree to take part in the study, you will be asked to do the following:

1. Complete the provided questionnaire, and

2. Mail the questionnaire in the provided return envelope.

There is no cost or payment to you. If you have questions while taking part in the study, please feel free to contact me at mpapa002@fiu.edu or 305-439-2486.

If you would like to talk with someone about your rights as a participant in this research study or about ethical issues concerning this project, you may contact the Florida International University's Office of Research Integrity by phone at 305-348-2494 or by email at ori@fiu.edu.

You may keep a copy of this form for your records.

Thank you for your time.

Sincerely,

Michael Paparesta

Ph. D. Candidate

School of Public Affairs

Florida International University 
1) What county is your property located?

Broward

Orange

Duval

2) Which best describes the location of your property?

Urban

Suburban

Rural, farm

Rural, nonfarm

3) What type of property do you own?

Single-family house

Condominium

Townhome

Duplex

Apartment (4 units or less)

Other (please specify)

4) How long have you owned your property (estimated or actual)? years Months

5) Please indicate the year (estimated or actual) that your property was built.

6) What is the approximate square footage of your property?

7) Does the property serve as your primary residence?

Yes No

8) Does the property have an exemption (if no, skip to \#11)? Yes No

9) If yes, what type of exemption? (Check all that apply) Homestead

Seniors

Long-term Seniors

Disability

Veterans

Other (please specify)

10) Have you ever contacted your county's property appraiser/tax assessor to question the value of your property? Yes No

11) If yes, what was the result of your discussion with the property appraiser/tax assessor? Value was increased

No change to value Value was decreased 
12) Are you aware the value of your property can be appealed on a yearly basis?

Yes $\quad$ No

13) If yes, have you ever filed an appeal with the Value Adjustment Board? (if no, skip to \#18) Yes No

14) If you did file an appeal, did you use a representative to appeal the property's value? Yes No

15) If you have filed an appeal, was a reduction in value obtained?

Yes No

16) If you have filed an appeal, what was your motivation to file? (Check all that apply) An increase in property value An increase in the amount of taxes due Sales of properties in area indicated a lower value Error in property appraiser's records (for example, incorrect measurement) Property tax agent's advertisement Media report Word of mouth Other (please specify)

17) Do you own any other properties?

Yes No

18) If you do own other properties, which best describes the property type? (Check all that apply)

Second Home

Time-Share

Commercial

Vacant Land

Other (please specify)

19) If you do own other properties, have you ever filed an appeal for those properties, with the Value Adjustment Board? (if no, skip to \#21)

Yes No

20) If you have filed an appeal for the other properties, was a reduction obtained? Yes No 
21) Please indicate your level of agreement or disagreement with the following statements concerning the use of property taxes.

(5)

Strongly

Agree
(2)
(3) Agree

Neutral

Disagree Strongly Disagree

\begin{tabular}{|c|c|c|}
\hline $\begin{array}{l}\text { Money collected from property taxes is } \\
\text { used in an efficient manner }\end{array}$ & & \\
\hline $\begin{array}{l}\text { Property taxes are a fair way to raise } \\
\text { money for local services }\end{array}$ & & \\
\hline $\begin{array}{l}\text { Higher property taxes equal better local } \\
\text { services }\end{array}$ & & \\
\hline $\begin{array}{l}\text { I prefer property taxes when compared } \\
\text { to state income taxes }\end{array}$ & & \\
\hline $\begin{array}{l}\text { My property taxes are fair when } \\
\text { compared to my neighbors }\end{array}$ & & \\
\hline
\end{tabular}

22) Please rank the following local government services in order of importance (5) being the most important, (1) being the least important.

Opinion of Government Services Delivery Rank

\begin{tabular}{|l|l|}
\hline Public Safety (Police, Fire etc.) & \\
\hline Education & \\
\hline Infrastructure (Roads, Sewers, etc.) & \\
\hline Libraries & \\
\hline Water Management & \\
\hline
\end{tabular}

23) Please indicate your level of agreement or disagreement with the following statements concerning the opinions of your county government.

(5) (4)

Opinion of your county government Strongly Agree

(3)

(2)

Agree

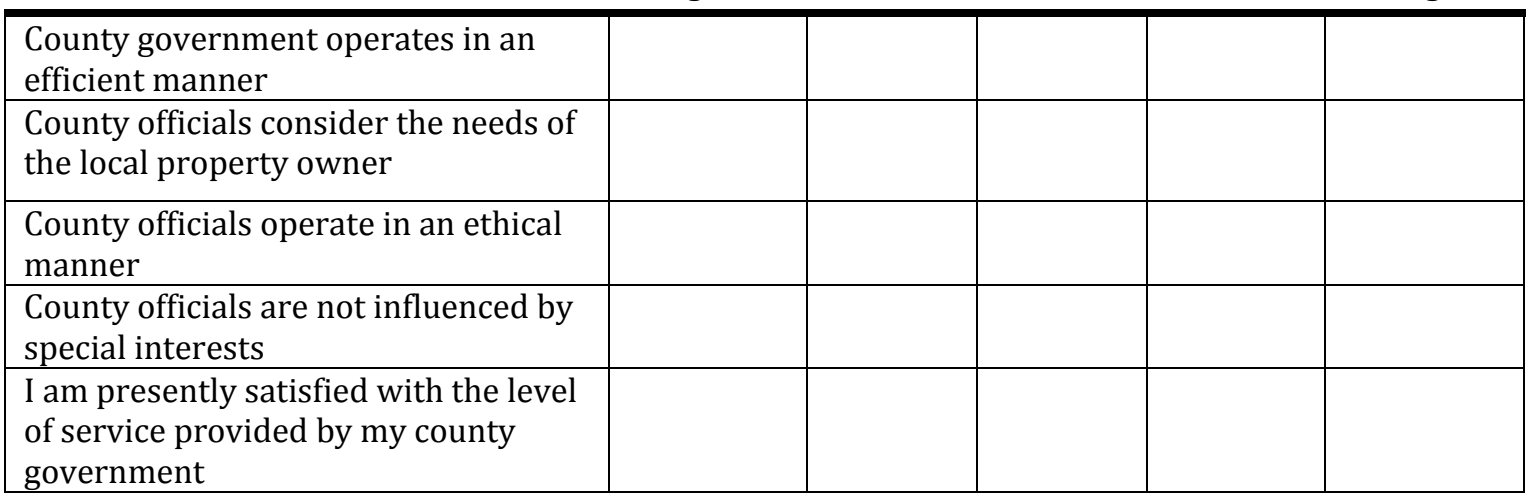

24) Which of the following household budget items represents your greatest concern? (choose one)

Flood Insurance

Hurricane Insurance

Property Taxes

Federal Income Taxes 
25) What is your highest level of education?

Some high school or less

High school graduate

Some college

Four-year-college graduate

Juris Doctorate

Graduate degree - other

26) What category best describes your occupation?

Professional

Clerical/Secretarial

Sales

Service

Labor (other than construction and agriculture)

Construction

Agriculture

Other (please specify)

27) Please indicate your estimated total annual household income, before taxes:

28) Which best describes your political affiliation?

Republican

Democrat

No Political Affiliation

Other (please specify)

29) What is your marital status?

Single

Married or Domestic Partnership

Widowed

Divorced

Separated

30) Please indicate your age

31) Please indicate your race or ethnicity:

American Indian or Alaska Native

Asian

Black or African American

Hispanic or Latino

Native Hawaiian or Other Pacific Islander

White (Non-Hispanic) 


\section{SURVEY DATABASE CODEBOOK}

\begin{tabular}{|c|c|c|c|c|}
\hline VARIABLE NAME & VARIABLE DESCRIPTION & $\begin{array}{l}\text { VARIABLE } \\
\text { TYPE }\end{array}$ & \multicolumn{2}{|c|}{ ADDITIONAL NOTE(S) } \\
\hline ID_NUM & $\begin{array}{l}\text { IDENTIFICATION NUMBER - a unique number used to identify } \\
\text { each respondent's survey. }\end{array}$ & INTERVAL & & \\
\hline \multirow[t]{6}{*}{ PA_GRP_NUM } & \multirow{6}{*}{$\begin{array}{l}\text { PROPERTY APPRAISER GROUP NUMBER - FDOR created } \\
\text { variable used to further stratify the active strata into groups used in the } \\
\text { FDOR's statistical analysis and approval process. }\end{array}$} & \multirow{6}{*}{ NOMINAL } & 1 & GRP 1 \\
\hline & & & 2 & GRP 2 \\
\hline & & & 3 & GRP 3 \\
\hline & & & 4 & GRP 4 \\
\hline & & & 5 & GRP 5 \\
\hline & & & 9 & MISSING \\
\hline \multirow[t]{4}{*}{ PROP_CNTY } & \multirow{4}{*}{$\begin{array}{l}\text { PROPERTY COUNTY - indicates which county the property is } \\
\text { located. }\end{array}$} & \multirow[t]{4}{*}{ NOMINAL } & 1 & BROWARD \\
\hline & & & 2 & ORANGE \\
\hline & & & 3 & DUVAL \\
\hline & & & 9 & MISSING \\
\hline \multirow[t]{5}{*}{ PROP_LOC } & \multirow{5}{*}{$\begin{array}{l}\text { PROPERTY LOCATION - Indicates whether the property is located } \\
\text { in an urban, suburban, rural farm, or rural nonfarm area. }\end{array}$} & \multirow[t]{5}{*}{ NOMINAL } & 1 & URBAN \\
\hline & & & 2 & SUBURBAN \\
\hline & & & 3 & RURAL FARM \\
\hline & & & 4 & RURAL NONFARM \\
\hline & & & 9 & MISSING \\
\hline \multirow[t]{7}{*}{ PROP_TYPE } & \multirow[t]{7}{*}{ PROPERTY TYPE - Indicates the property type. } & \multirow[t]{7}{*}{ NOMINAL } & 1 & SINGLE FAM \\
\hline & & & 2 & CONDO \\
\hline & & & 3 & TOWNHOME \\
\hline & & & 4 & DUPLEX \\
\hline & & & 5 & APARTMENT \\
\hline & & & 6 & OTHER \\
\hline & & & 9 & MISSING \\
\hline \multirow[t]{2}{*}{ YRS_OWN } & \multirow{2}{*}{$\begin{array}{l}\text { YEARS OWNED - Indicates how many years the owner has owned } \\
\text { the property. }\end{array}$} & \multirow[t]{2}{*}{ INTERVAL } & & \\
\hline & & & 99999 & MISSING \\
\hline \multirow[t]{2}{*}{ BLDG_YR_BLT } & \multirow{2}{*}{ BUILDING YEAR BUILT - Indicates the age of the property. } & \multirow[t]{2}{*}{ INTERVAL } & & \\
\hline & & & 99999 & MISSING \\
\hline \multirow[t]{2}{*}{ BLDG_SIZE } & \multirow[t]{2}{*}{ BUILDING SIZE - indicates the size of the building. } & \multirow[t]{2}{*}{ INTERVAL } & & \\
\hline & & & 99999 & MISSING \\
\hline
\end{tabular}




\begin{tabular}{|c|c|c|c|c|}
\hline \multirow{4}{*}{\begin{tabular}{|l|} 
VARIABLE NAME \\
PRIM_RESID
\end{tabular}} & \multirow{4}{*}{$\begin{array}{l}\text { VARIABLE DESCRIPTION } \\
\text { PRIMARY RESIDENCE - indicates whether the property serves as } \\
\text { the owner's primary residence. }\end{array}$} & \multirow{4}{*}{\begin{tabular}{|l|} 
VARIABLE \\
TYPE \\
NOMINAL
\end{tabular}} & \multicolumn{2}{|c|}{ ADDITIONAL NOTE(S) } \\
\hline & & & 1 & YES \\
\hline & & & 0 & NO \\
\hline & & & 9 & MISSING \\
\hline \multirow[t]{3}{*}{ EXEMPT } & \multirow{3}{*}{$\begin{array}{l}\text { EXEMPTION - indicates whether the property owner has applied and } \\
\text { been approved for a property tax exemption. }\end{array}$} & \multirow[t]{3}{*}{ NOMINAL } & 1 & YES \\
\hline & & & \begin{tabular}{|l|}
0 \\
\end{tabular} & $\mathrm{NO}$ \\
\hline & & & 9 & MISSING \\
\hline \multirow[t]{3}{*}{ HEX } & \multirow{3}{*}{$\begin{array}{l}\text { HOMESTEAD EXEMPTION - indicates whether the property owner } \\
\text { has a homestead exemption. }\end{array}$} & \multirow[t]{3}{*}{ NOMINAL } & 1 & YES \\
\hline & & & 0 & NO \\
\hline & & & 9 & MISSING \\
\hline \multirow[t]{3}{*}{ SENIOR } & \multirow{3}{*}{$\begin{array}{l}\text { SENIOR EXEMPTION - indicates whether the property owner has a } \\
\text { senior citizen's exemption. }\end{array}$} & \multirow[t]{3}{*}{ NOMINAL } & 1 & YES \\
\hline & & & 0 & NO \\
\hline & & & 9 & MISSING \\
\hline \multirow[t]{3}{*}{ LONG_SENIOR } & \multirow{3}{*}{$\begin{array}{l}\text { LONG TERM SENIOR EXEMPTION - indicates whether the } \\
\text { property owner has a long-term senior exemption. }\end{array}$} & \multirow[t]{3}{*}{ NOMINAL } & 1 & YES \\
\hline & & & 0 & $\mathrm{NO}$ \\
\hline & & & 9 & MISSING \\
\hline \multirow[t]{3}{*}{ DISABLE } & \multirow{3}{*}{$\begin{array}{l}\text { DISABILITY EXEMPTION - indicates whether the property owner } \\
\text { has a disability exemption. }\end{array}$} & \multirow[t]{3}{*}{ NOMINAL } & 1 & YES \\
\hline & & & 0 & NO \\
\hline & & & 9 & MISSING \\
\hline \multirow[t]{3}{*}{ VETERAN } & \multirow{3}{*}{$\begin{array}{l}\text { VETERAN EXEMPTION - indicates whether the property owner has } \\
\text { a veteran exemption. }\end{array}$} & \multirow[t]{3}{*}{ NOMINAL } & 1 & YES \\
\hline & & & 0 & NO \\
\hline & & & 9 & MISSING \\
\hline \multirow[t]{3}{*}{ OTHER_EX } & \multirow{3}{*}{$\begin{array}{l}\text { OTHER EXEMPTION - indicates whether there is another exemption } \\
\text { (not listed) associated with the property. }\end{array}$} & \multirow[t]{3}{*}{ NOMINAL } & 1 & YES \\
\hline & & & 0 & $\mathrm{NO}$ \\
\hline & & & 9 & MISSING \\
\hline \multirow[t]{3}{*}{ INFORM_APPEAL } & \multirow{3}{*}{$\begin{array}{l}\text { INFORMAL APPEAL - indicates whether the property owner has } \\
\text { ever contacted their respective property appraiser to review the value } \\
\text { of their property. }\end{array}$} & \multirow[t]{3}{*}{ NOMINAL } & 1 & YES \\
\hline & & & 0 & NO \\
\hline & & & 9 & MISSING \\
\hline \multirow[t]{5}{*}{ INFORM_RESULT } & \multirow{5}{*}{$\begin{array}{l}\text { INFORMAL APPEAL RESULT - indicates the property has received } \\
\text { a reduction because of an informal appeal. }\end{array}$} & NOMINAL & 1 & INCREASE \\
\hline & & & 2 & NO CHANGE \\
\hline & & & 3 & DECREASE \\
\hline & & & \begin{tabular}{|l|}
99 \\
\end{tabular} & NOT APP \\
\hline & & & 9 & MISS \\
\hline
\end{tabular}




\begin{tabular}{|c|c|c|c|c|}
\hline VARIABLE NAME & VARIABLE DESCRIPTION & VARIABLE & \multicolumn{2}{|c|}{ ADDITIONAL NOTE(S) } \\
\hline \multirow[t]{3}{*}{ APPEAL_AWARE } & \multirow{3}{*}{$\begin{array}{l}\text { APPEAL AWARENESS - indicates whether the property owner is } \\
\text { aware of the formal appeal process. }\end{array}$} & \multirow{3}{*}{ NOMINAL } & 1 & YES \\
\hline & & & 0 & NO \\
\hline & & & 9 & MISSING \\
\hline \multirow[t]{3}{*}{ APPEAL_FILE } & \multirow{3}{*}{$\begin{array}{l}\text { APPEAL FILED - indicates whether the property owner has ever } \\
\text { filed a formal appeal. }\end{array}$} & \multirow[t]{3}{*}{ NOMINAL } & 1 & YES \\
\hline & & & 0 & NO \\
\hline & & & 9 & MISSING \\
\hline \multirow[t]{4}{*}{ PROFESS } & \multirow{4}{*}{$\begin{array}{l}\text { PROFESSIONAL REPRESENTATION - indicates whether the } \\
\text { property owner has ever hired a property tax agent to represent him or } \\
\text { her. }\end{array}$} & \multirow[t]{4}{*}{ NOMINAL } & 1 & YES \\
\hline & & & 0 & NO \\
\hline & & & 99 & NOT APP \\
\hline & & & 9 & MISSING \\
\hline \multirow[t]{4}{*}{ APPEAL_RESULT } & \multirow{4}{*}{$\begin{array}{l}\text { APPEAL RESULT - indicates whether a reduction was achieved } \\
\text { during the appeal process. }\end{array}$} & \multirow[t]{4}{*}{ NOMINAL } & 1 & YES \\
\hline & & & 0 & NO \\
\hline & & & 99 & NOT APP \\
\hline & & & 9 & MISSING \\
\hline \multirow{10}{*}{ APPEAL_MOTIV } & \multirow{10}{*}{$\begin{array}{l}\text { APPEAL MOTIVATION - indicates the property owner's motivation } \\
\text { for filing an appeal. }\end{array}$} & \multirow{10}{*}{ NOMINAL } & 1 & VALUE INCREASE \\
\hline & & & \begin{tabular}{|l|}
2 \\
\end{tabular} & TAX INCREASE \\
\hline & & & 3 & SALES \\
\hline & & & 4 & ERROR \\
\hline & & & 5 & ADVERTISE \\
\hline & & & 6 & MEDIA \\
\hline & & & 7 & WOM \\
\hline & & & 8 & OTHER \\
\hline & & & 99 & NOT APP \\
\hline & & & 9 & MISSING \\
\hline \multirow[t]{3}{*}{ MULTI_PROP } & \multirow{3}{*}{$\begin{array}{l}\text { MULTIPLE PROPERTIES - indicates whether the property owner } \\
\text { owns multiple properties. }\end{array}$} & \multirow[t]{3}{*}{ NOMINAL } & 1 & YES \\
\hline & & & 0 & NO \\
\hline & & & 9 & MISSING \\
\hline \multirow[t]{4}{*}{ SEC_HOME } & \multirow{4}{*}{$\begin{array}{l}\text { SECOND HOME - indicates whether the property owner owns a } \\
\text { second home. }\end{array}$} & \multirow[t]{4}{*}{ NOMINAL } & 1 & YES \\
\hline & & & 0 & NO \\
\hline & & & 9 & MISSING \\
\hline & & & 99 & NOT APP \\
\hline
\end{tabular}




\begin{tabular}{|c|c|c|c|c|}
\hline VARIABLE NAME & VARIABLE DESCRIPTION & VARIABLE & \multicolumn{2}{|c|}{ ADDITIONAL NOTE(S) } \\
\hline \multirow[t]{4}{*}{ TIME_SHARE } & \multirow{4}{*}{$\begin{array}{l}\text { TIME SHARE - indicates whether the property owner owns a time- } \\
\text { share. }\end{array}$} & \multirow{4}{*}{ NOMINAL } & 1 & YES \\
\hline & & & 0 & NO \\
\hline & & & 9 & MISSING \\
\hline & & & 99 & NOT APP \\
\hline \multirow[t]{4}{*}{ COMM } & \multirow{4}{*}{$\begin{array}{l}\text { COMMERCIAL - indicates whether the property owner owns a } \\
\text { commercial property. }\end{array}$} & \multirow[t]{4}{*}{ NOMINAL } & 1 & YES \\
\hline & & & 0 & $\mathrm{NO}$ \\
\hline & & & 9 & MISSING \\
\hline & & & 99 & NOT APP \\
\hline \multirow[t]{4}{*}{ VACANT } & \multirow{4}{*}{ VACANT - indicates whether the property owner owns vacant land. } & \multirow[t]{4}{*}{ NOMINAL } & 1 & YES \\
\hline & & & 0 & NO \\
\hline & & & 9 & MISSING \\
\hline & & & 99 & NOT APP \\
\hline \multirow[t]{4}{*}{ OTHER_PROP } & \multirow{4}{*}{$\begin{array}{l}\text { OTHER PROPERTY - indicates whether the property owner owns } \\
\text { other real estate not listed. }\end{array}$} & \multirow[t]{4}{*}{ NOMINAL } & 1 & YES \\
\hline & & & 0 & $\mathrm{NO}$ \\
\hline & & & 9 & MISSING \\
\hline & & & 99 & NOT APP \\
\hline \multirow[t]{4}{*}{ MULTI_PROP_APPEAL } & \multirow{4}{*}{$\begin{array}{l}\text { MULTIPLE PROPERTY APPEAL - if the property owner owns } \\
\text { multiple properties, this variable indicates whether the property owner } \\
\text { has appealed any of those properties. }\end{array}$} & \multirow{4}{*}{ NOMINAL } & 1 & YES \\
\hline & & & 0 & NO \\
\hline & & & 9 & MISSING \\
\hline & & & 99 & NOT APP \\
\hline \multirow[t]{4}{*}{ MULTI_APP_RSLT } & \multirow{4}{*}{$\begin{array}{l}\text { MULTIPLE APPEAL RESULT - if the property owner owns } \\
\text { multiple properties, and has appealed those properties, this variable } \\
\text { indicates the result of the appeals. }\end{array}$} & \multirow[t]{4}{*}{ NOMINAL } & 1 & YES \\
\hline & & & 0 & NO \\
\hline & & & 9 & MISSING \\
\hline & & & 99 & NOT APP \\
\hline \multirow[t]{6}{*}{ TAX_EFF_USE } & \multirow{6}{*}{$\begin{array}{l}\text { TAX EFFECTIVE USE - indicates the property owner's opinion as to } \\
\text { whether the revenues collected from property taxes are used in an } \\
\text { efficient manner. }\end{array}$} & \multirow[t]{6}{*}{ ORDINAL } & 5 & S AGREE \\
\hline & & & 4 & AGREE \\
\hline & & & 3 & NEUTRAL \\
\hline & & & 2 & DISAGREE \\
\hline & & & 1 & S DISAGREE \\
\hline & & & 9 & MISSING \\
\hline
\end{tabular}




\begin{tabular}{|c|c|c|c|c|}
\hline VARIABLE NAME & VARIABLE DESCRIPTION & VARIABLE & \multicolumn{2}{|c|}{ ADDITIONAL NOTE(S) } \\
\hline \multirow[t]{6}{*}{ TAX_FAIR } & \multirow{6}{*}{$\begin{array}{l}\text { TAX FAIRNESS - indicates the property owner's opinion as whether } \\
\text { property taxes are a fair way to raise money for local services. }\end{array}$} & \multirow{6}{*}{ ORDINAL } & 5 & S AGREE \\
\hline & & & 4 & AGREE \\
\hline & & & 3 & NEUTRAL \\
\hline & & & 2 & DISAGREE \\
\hline & & & 1 & S DISAGREE \\
\hline & & & 9 & MISSING \\
\hline \multirow[t]{6}{*}{ TAX_SERV_LEV } & \multirow{6}{*}{$\begin{array}{l}\text { TAX SERVICE LEVEL - indicates the property owner's opinion as } \\
\text { to whether higher property taxes equate to better local services. }\end{array}$} & \multirow[t]{6}{*}{ ORDINAL } & 5 & S AGREE \\
\hline & & & 4 & AGREE \\
\hline & & & 3 & NEUTRAL \\
\hline & & & 2 & DISAGREE \\
\hline & & & 1 & S DISAGREE \\
\hline & & & 9 & MISSING \\
\hline \multirow[t]{6}{*}{ PTAX_VS_ITAX } & \multirow{6}{*}{$\begin{array}{l}\text { PROPERTY TAX VERSUS INCOME TAX - indicates the property } \\
\text { owner's opinion concerning property taxes when compared to state } \\
\text { income taxes. }\end{array}$} & \multirow[t]{6}{*}{ ORDINAL } & 5 & S AGREE \\
\hline & & & 4 & AGREE \\
\hline & & & 3 & NEUTRAL \\
\hline & & & 2 & DISAGREE \\
\hline & & & 1 & S DISAGREE \\
\hline & & & 9 & MISSING \\
\hline \multirow[t]{6}{*}{ TAX_FAIR_COMP } & \multirow{6}{*}{$\begin{array}{l}\text { TAX FAIR COMPARED TO NEIGHBOR - indicates the property } \\
\text { owner's opinion concerning their property taxes when compared to } \\
\text { their neighbors. }\end{array}$} & \multirow[t]{6}{*}{ ORDINAL } & 5 & S AGREE \\
\hline & & & 4 & AGREE \\
\hline & & & 3 & NEUTRAL \\
\hline & & & 2 & DISAGREE \\
\hline & & & 1 & S DISAGREE \\
\hline & & & 9 & MISSING \\
\hline \multirow[t]{6}{*}{ SERV_DELV_SAFE } & \multirow{6}{*}{$\begin{array}{l}\text { SERVICE DELIVERY SAFETY - indicates where the property } \\
\text { owner ranks public safety in terms of importance as compared to } \\
\text { education, infrastructure, libraries, and water management. }\end{array}$} & \multirow[t]{6}{*}{ ORDINAL } & 5 & VERY IMP \\
\hline & & & 4 & IMP \\
\hline & & & 3 & MOD IMP \\
\hline & & & 2 & LITTLE IMP \\
\hline & & & 1 & LEAST IMP \\
\hline & & & 9 & MISSING \\
\hline
\end{tabular}




\begin{tabular}{|c|c|c|c|c|}
\hline VARIABLE NAME & VARIABLE DESCRIPTION & VARIABLE & \multicolumn{2}{|c|}{ ADDITIONAL NOTE(S) } \\
\hline \multirow[t]{6}{*}{ SERV_DELV_EDU } & \multirow{6}{*}{$\begin{array}{l}\text { SERVICE DELIVERY EDUCATION - indicates where the property } \\
\text { owner ranks education in terms of importance as compared to public } \\
\text { safety, infrastructure, libraries, and water management. }\end{array}$} & \multirow{6}{*}{ ORDINAL } & 5 & VERY IMP \\
\hline & & & 4 & IMP \\
\hline & & & 3 & MOD IMP \\
\hline & & & 2 & LITTLE IMP \\
\hline & & & 1 & LEAST IMP \\
\hline & & & 9 & MISSING \\
\hline \multirow[t]{6}{*}{ SERV_DELV_STRU } & \multirow{6}{*}{$\begin{array}{l}\text { SERVICE DELIVERY INFRASTRUCTURE - indicates where the } \\
\text { property owner ranks infrastructure in terms of importance as } \\
\text { compared to public safety, education, libraries, and water } \\
\text { management. }\end{array}$} & \multirow[t]{6}{*}{ ORDINAL } & 5 & VERY IMP \\
\hline & & & 4 & IMP \\
\hline & & & 3 & MOD IMP \\
\hline & & & 2 & LITTLE IMP \\
\hline & & & 1 & LEAST IMP \\
\hline & & & 9 & MISSING \\
\hline \multirow[t]{6}{*}{ SERV_DELV_LIB } & \multirow{6}{*}{$\begin{array}{l}\text { SERVICE DELIVERY LIBRARY - indicates where the property } \\
\text { owner ranks library services in terms of importance as compared to } \\
\text { public safety, education, infrastructure, and water management. }\end{array}$} & \multirow[t]{6}{*}{ ORDINAL } & 5 & VERY IMP \\
\hline & & & 4 & IMP \\
\hline & & & 3 & MOD IMP \\
\hline & & & 2 & LITTLE IMP \\
\hline & & & 1 & LEAST IMP \\
\hline & & & 9 & MISSING \\
\hline \multirow[t]{6}{*}{ SERV_WAT } & \multirow{6}{*}{$\begin{array}{l}\text { SERVICE DELIVERY WATER - indicates where the property } \\
\text { owner ranks water management in terms of importance as compared } \\
\text { to public safety, education, infrastructure, and libraries. }\end{array}$} & \multirow[t]{6}{*}{ ORDINAL } & 5 & VERY IMP \\
\hline & & & 4 & IMP \\
\hline & & & 3 & MOD IMP \\
\hline & & & 2 & LITTLE IMP \\
\hline & & & 1 & LEAST IMP \\
\hline & & & 9 & MISSING \\
\hline \multirow[t]{6}{*}{ EFF_OPER } & \multirow{6}{*}{$\begin{array}{l}\text { EFFICIENT OPERATION - indicates whether the property owner } \\
\text { believes county government operates in an efficient manner. }\end{array}$} & \multirow[t]{6}{*}{ ORDINAL } & 5 & S AGREE \\
\hline & & & 4 & AGREE \\
\hline & & & 3 & NEUTRAL \\
\hline & & & 2 & DISAGREE \\
\hline & & & 1 & S DISAGREE \\
\hline & & & 9 & MISSING \\
\hline
\end{tabular}




\begin{tabular}{|c|c|c|c|c|}
\hline VARIABLE NAME & VARIABLE DESCRIPTION & VARIABLE & \multicolumn{2}{|c|}{ ADDITIONAL NOTE(S) } \\
\hline \multirow[t]{6}{*}{ LOCAL_NEED } & \multirow{6}{*}{$\begin{array}{l}\text { LOCAL NEED - indicates whether the property owner believes } \\
\text { county officials consider the needs of local property owners when } \\
\text { making policy decisions. }\end{array}$} & \multirow{6}{*}{ ORDINAL } & 5 & S AGREE \\
\hline & & & 4 & AGREE \\
\hline & & & 3 & NEUTRAL \\
\hline & & & 2 & DISAGREE \\
\hline & & & 1 & S DISAGREE \\
\hline & & & 9 & MISSING \\
\hline \multirow[t]{6}{*}{ GOV_ETHIC } & \multirow{6}{*}{$\begin{array}{l}\text { GOVERNMNET ETHICS - indicates whether the property owner } \\
\text { believes county officials operate in an ethical manner. }\end{array}$} & \multirow[t]{6}{*}{ ORDINAL } & 5 & S AGREE \\
\hline & & & 4 & AGREE \\
\hline & & & 3 & NEUTRAL \\
\hline & & & 2 & DISAGREE \\
\hline & & & 1 & S DISAGREE \\
\hline & & & 9 & MISSING \\
\hline \multirow[t]{6}{*}{ SPEC_INT } & \multirow{6}{*}{$\begin{array}{l}\text { SPECIAL INTEREST - indicates whether the property owner } \\
\text { believes special interests influence government officials. }\end{array}$} & \multirow[t]{6}{*}{ ORDINAL } & 5 & S AGREE \\
\hline & & & 4 & AGREE \\
\hline & & & 3 & NEUTRAL \\
\hline & & & 2 & DISAGREE \\
\hline & & & 1 & S DISAGREE \\
\hline & & & 9 & MISSING \\
\hline \multirow[t]{6}{*}{ GOV_SATIS } & \multirow{6}{*}{$\begin{array}{l}\text { GOVERNMENT SATISFACTION - indicates the property owner's } \\
\text { level of satisfaction with the delivery of county government services. }\end{array}$} & \multirow[t]{6}{*}{ ORDINAL } & 5 & S AGREE \\
\hline & & & 4 & AGREE \\
\hline & & & 3 & NEUTRAL \\
\hline & & & 2 & DISAGREE \\
\hline & & & 1 & S DISAGREE \\
\hline & & & 9 & MISSING \\
\hline \multirow[t]{5}{*}{ HBUD_CONC_FL } & \multirow{5}{*}{$\begin{array}{l}\text { HOUSEHOLD BUDGET CONCERN FLOOD INSURANCE - } \\
\text { indicates where the property owner ranks the impact of flood } \\
\text { insurance on their household budget. }\end{array}$} & \multirow[t]{5}{*}{ ORDINAL } & 4 & VERY IMP \\
\hline & & & 3 & MOD IMP \\
\hline & & & 2 & IMPORT \\
\hline & & & 1 & LEAST IMP \\
\hline & & & 9 & MISS \\
\hline
\end{tabular}




\begin{tabular}{|c|c|c|c|c|}
\hline VARIABLE NAME & VARIABLE DESCRIPTION & VARIABLE & \multicolumn{2}{|c|}{ ADDITIONAL NOTE(S) } \\
\hline \multirow{5}{*}{ HBUD_CONC_HR } & \multirow{5}{*}{$\begin{array}{l}\text { HOUSEHOLD BUDGET CONCERN HURRICANCE INSURANCE } \\
\text { - indicates where the property owner ranks the impact of hurricane } \\
\text { insurance on their household budget. }\end{array}$} & \multirow{5}{*}{ ORDINAL } & 4 & VERY IMP \\
\hline & & & 3 & MOD IMP \\
\hline & & & 2 & IMPORT \\
\hline & & & 1 & LEAST IMP \\
\hline & & & 9 & MISS \\
\hline \multirow[t]{5}{*}{ HBUD_CONC_PT } & \multirow{5}{*}{$\begin{array}{l}\text { HOUSEHOLD BUDGET CONCERN PROPERTY TAXES - } \\
\text { indicates where the property owner ranks the impact of property taxes } \\
\text { on their household budget. }\end{array}$} & \multirow[t]{5}{*}{ ORDINAL } & 4 & VERY IMP \\
\hline & & & 3 & MOD IMP \\
\hline & & & 2 & IMPORT \\
\hline & & & 1 & LEAST IMP \\
\hline & & & 9 & MISS \\
\hline \multirow{5}{*}{ HBUD_CONC_IT } & \multirow{5}{*}{$\begin{array}{l}\text { HOUSEHOLD BUDGET CONCERN FEDERAL INCOME TAX - } \\
\text { indicates where the property owner ranks the impact of the federal } \\
\text { income tax on their household budget. }\end{array}$} & \multirow{5}{*}{ ORDINAL } & 4 & VERY IMP \\
\hline & & & 3 & MOD IMP \\
\hline & & & 2 & IMPORT \\
\hline & & & 1 & LEAST IMP \\
\hline & & & 9 & MISS \\
\hline \multirow[t]{7}{*}{ EDUC } & \multirow{7}{*}{$\begin{array}{l}\text { EDUCATION LEVEL - indicates the education level of the property } \\
\text { owner. }\end{array}$} & \multirow[t]{7}{*}{ NOMINAL } & 1 & SOME HIGH \\
\hline & & & 2 & HIGH \\
\hline & & & 3 & SOME COLL \\
\hline & & & 4 & COLLEGE \\
\hline & & & 5 & JURID DOC \\
\hline & & & 6 & GRADUATE \\
\hline & & & 9 & MISSING \\
\hline \multirow[t]{9}{*}{ OCCUP } & \multirow[t]{9}{*}{ OCCUPATION - describes the occupation of the property owner. } & \multirow[t]{9}{*}{ NOMINAL } & 1 & PROFF \\
\hline & & & 2 & CLERIC \\
\hline & & & 3 & SALES \\
\hline & & & 4 & SERVICE \\
\hline & & & 5 & LABOR \\
\hline & & & 6 & CONST \\
\hline & & & 7 & RETIRED \\
\hline & & & 8 & OTHER \\
\hline & & & 9 & MISSING \\
\hline
\end{tabular}




\begin{tabular}{|c|c|c|c|c|}
\hline VARIABLE NAME & VARIABLE DESCRIPTION & VARIABLE & \multicolumn{2}{|c|}{ ADDITIONAL NOTE(S) } \\
\hline \multirow[t]{2}{*}{ INCOME } & \multirow{2}{*}{$\begin{array}{l}\text { INCOME - indicates the estimated total annual household income } \\
\text { before taxes. }\end{array}$} & \multirow[t]{2}{*}{ RATIO } & & \\
\hline & & & 99999 & MISSING \\
\hline \multirow[t]{5}{*}{ POLT_AFF } & \multirow{5}{*}{$\begin{array}{l}\text { POLITICAL AFFILIATION - indicates how the property owner } \\
\text { aligns politically. }\end{array}$} & \multirow[t]{5}{*}{ NOMINAL } & 1 & REP \\
\hline & & & 2 & DEM \\
\hline & & & 3 & NPA \\
\hline & & & 4 & OTHER \\
\hline & & & 9 & MISSING \\
\hline \multirow[t]{6}{*}{ MART_STAT } & \multirow{6}{*}{$\begin{array}{l}\text { MARITAL STATUS - indicates the marital status of the property } \\
\text { owner. }\end{array}$} & \multirow[t]{6}{*}{ NOMINAL } & 1 & SIN \\
\hline & & & 2 & MAR \\
\hline & & & 3 & WID \\
\hline & & & 4 & DIV \\
\hline & & & 5 & SEP \\
\hline & & & 9 & MISSING \\
\hline \multirow[t]{2}{*}{ AGE } & \multirow[t]{2}{*}{ AGE - indicates the age of the property owner. } & \multirow[t]{2}{*}{ INTERVAL } & & \\
\hline & & & 99999 & MISSING \\
\hline \multirow[t]{7}{*}{ RACE } & \multirow[t]{7}{*}{ RACE - indicates the race or ethnicity of the property owner. } & \multirow[t]{7}{*}{ NOMINAL } & 1 & NAT \\
\hline & & & 2 & ASIA \\
\hline & & & 3 & BLK \\
\hline & & & 4 & HIS \\
\hline & & & 5 & PAC \\
\hline & & & 6 & WHT \\
\hline & & & 9 & MISS \\
\hline
\end{tabular}




\section{APPEALS DATABASE CODEBOOK}

\begin{tabular}{|c|c|c|c|}
\hline VARIABLE NAME & VARIABLE DESCRIPTION & $\begin{array}{c}\text { VARIABLE } \\
\text { TYPE }\end{array}$ & ADDITIONAL NOTE(S) \\
\hline PARCEL_ID & $\begin{array}{l}\text { PARCEL INDENTIFICATION } \\
\text { NUMBER - A unique numerical } \\
\text { identifier assigned to each parcel. }\end{array}$ & Nominal & \\
\hline PET_NUM & $\begin{array}{l}\text { PETITION NUMBER - A unique } \\
\text { numerical identifier assigned to each } \\
\text { petitioned property for a tax year. }\end{array}$ & Nominal & \\
\hline PET_AGNT & $\begin{array}{l}\text { PETITION AGENT- Name of the agent } \\
\text { representing the petitioned property at } \\
\text { the VAB. If there is no agent, } \\
\text { PET_AGNT will reflect the PET_OWN. }\end{array}$ & Nominal & \\
\hline PET_OWN & $\begin{array}{l}\text { PETITION OWNER - Name of the } \\
\text { owner of the property as of January } 1^{\text {st }} \text { of } \\
\text { the respective tax year. }\end{array}$ & Nominal & \\
\hline AGENT & $\begin{array}{l}\text { AGENT - indicates whether the property } \\
\text { owner was represented by a professional. }\end{array}$ & $\begin{array}{l}\text { Categorical } \\
(\mathrm{Y} / \mathrm{N})\end{array}$ & $\begin{array}{l}\text { Includes real estate sales persons, } \\
\text { brokers, attorneys, title companies, } \\
\text { property tax reduction companies, and } \\
\text { tax services. }\end{array}$ \\
\hline JV_PRE_HEARING & $\begin{array}{l}\text { JUST VALUE PRE-HEARING - } \\
\text { Indicates the property appraiser's opinion } \\
\text { of market value prior to the VAB } \\
\text { hearing. }\end{array}$ & Ratio & \\
\hline JV_POST_HEARING & $\begin{array}{l}\text { JUST VALUE POST-HEARING - } \\
\text { Indicates the special magistrate's opinion } \\
\text { of market value after the VAB hearing. }\end{array}$ & Ratio & \\
\hline AV_PRE_HEARING & $\begin{array}{l}\text { ASSESSED VALUE PRE-HEARING - } \\
\text { reflects the market value less } \\
\text { consideration for assessment increase } \\
\text { limitations prior to the VAB hearing. }\end{array}$ & Ratio & \\
\hline
\end{tabular}




\begin{tabular}{|c|c|c|c|c|}
\hline VARIABLE NAME & VARIABLE DESCRIPTION & $\begin{array}{c}\text { VARIABLE } \\
\text { TYPE }\end{array}$ & \multicolumn{2}{|c|}{ ADDITIONAL NOTE(S) } \\
\hline AV_POST_HEARING & $\begin{array}{l}\text { ASSESSED VALUE POST-HEARING - } \\
\text { reflects value less consideration for } \\
\text { assessment increase limitations after the } \\
\text { VAB hearing. }\end{array}$ & Ratio & & \\
\hline EX_PRE_HEARING & $\begin{array}{l}\text { EXEMPTION PRE-HEARING - } \\
\text { Indicates the exemption amount prior to } \\
\text { the VAB hearing. }\end{array}$ & Ratio & & \\
\hline EX_POST_HEARING & $\begin{array}{l}\text { EXEMPTION POST-HEARING - } \\
\text { Indicates the exemption amount after the } \\
\text { VAB hearing. }\end{array}$ & Ratio & & \\
\hline TV_PRE_HEARING & $\begin{array}{l}\text { TAXABLE VALUE PRE-HEARING - } \\
\text { The assessed value of the property minus } \\
\text { any applicable exemptions prior to the } \\
\text { VAB hearing. }\end{array}$ & Ratio & & \\
\hline TV_POST_HEARING & $\begin{array}{l}\text { TAXABLE VALUE POST-HEARING - } \\
\text { The assessed value of the property minus } \\
\text { the amount of any applicable exemptions } \\
\text { after the VAB hearing. }\end{array}$ & Ratio & & \\
\hline FINDING & $\begin{array}{l}\text { FINDING - Description of VAB hearing } \\
\text { result. }\end{array}$ & Categorical & & \\
\hline \multirow[t]{6}{*}{ FINDING_CODE } & \multirow{6}{*}{$\begin{array}{l}\text { FINDING CODE - Variable used to } \\
\text { convey the result of the VAB hearing. }\end{array}$} & \multirow[t]{6}{*}{ Categorical } & Denied & 0 \\
\hline & & & Granted & 1 \\
\hline & & & Withdrawn & 2 \\
\hline & & & Resolved & 3 \\
\hline & & & Not Timely Filed & 4 \\
\hline & & & No Show & 5 \\
\hline BAS_STRT & $\begin{array}{l}\text { BASIC STRATUM - FDOR created } \\
\text { variable utilized to segregate the parcel } \\
\text { into a specific stratum for assessment } \\
\text { uniformity purposes. }\end{array}$ & Categorical & & \\
\hline
\end{tabular}




\begin{tabular}{|c|c|c|c|}
\hline VARIABLE NAME & VARIABLE DESCRIPTION & $\begin{array}{c}\text { VARIABLE } \\
\text { TYPE }\end{array}$ & ADDITIONAL NOTE(S) \\
\hline ATV_STRT & $\begin{array}{l}\text { ACTIVE STRATUM - FDOR created } \\
\text { variable used to identify the data to be } \\
\text { used in the tax year's assessment } \\
\text { uniformity analysis and tax roll approval } \\
\text { process. }\end{array}$ & Categorical & \\
\hline GRP_NUM & $\begin{array}{l}\text { GROUP NUMBER - FDOR created } \\
\text { variable used to further stratify the active } \\
\text { strata into groups used in the FDOR's } \\
\text { statistical analysis and approval process. }\end{array}$ & Categorical & \\
\hline DOR_UC & $\begin{array}{l}\text { DEPARTMENT OF REVENUE LAND } \\
\text { USE CODE - Represents the land use } \\
\text { codes associated with each type of } \\
\text { property. }\end{array}$ & Categorical & \\
\hline PA_UC & $\begin{array}{l}\text { PROPERTY APPRAISER LAND USE } \\
\text { CODE - Represents county internally } \\
\text { defined land use code. }\end{array}$ & Categorical & \\
\hline JV_PRE_XXXX & $\begin{array}{l}\text { JUST VALUE PRELIMINARY TAX } \\
\text { ROLL YEAR - Indicates the property } \\
\text { appraiser's opinion of market value (after } \\
\text { an adjustment for Florida Statutes } \\
\text { 193.011(1) and (8)) for the preliminary } \\
\text { tax roll for the respective tax year }\end{array}$ & Ratio & \\
\hline AV_SD_PRE_XXXX & $\begin{array}{l}\text { ASSESSED VALUE SCHOOL } \\
\text { DISTRICT PRELIMINARY TAX } \\
\text { ROLL YEAR - Indicates the assessed } \\
\text { value for school district assessments. } \\
\text { The } 10 \% \text { assessment increase limitation } \\
\text { on non-homestead property does not } \\
\text { apply to school district assessed value. }\end{array}$ & Ratio & \\
\hline
\end{tabular}




\begin{tabular}{|c|c|c|c|}
\hline VARIABLE NAME & VARIABLE DESCRIPTION & $\begin{array}{c}\text { VARIABLE } \\
\text { TYPE }\end{array}$ & ADDITIONAL NOTE(S) \\
\hline AV_NSD_PRE_XXXX & $\begin{array}{l}\text { ASSESSED VALUE NON-SCHOOL } \\
\text { DISTRICT PRELIMINARY TAX } \\
\text { ROLL YEAR - Indicates the assessed } \\
\text { value for non-school district taxing } \\
\text { authorities. Beginning in 2009, the 10\% } \\
\text { assessment increase limitation on non- } \\
\text { homestead property will apply only to } \\
\text { non-school district assessments. }\end{array}$ & Ratio & \\
\hline TV_SD_PRE_XXXX & $\begin{array}{l}\text { TAXABLE VALUE SCHOOL } \\
\text { DISTRICT PRELIMINARY TAX } \\
\text { ROLL YEAR - Reflects the taxable } \\
\text { value for school purposes, is based on } \\
\text { school-assessed value, and does not } \\
\text { include subtractions for the additional } \\
\$ 25,000 \text { or local option exemptions. }\end{array}$ & Ratio & \\
\hline TV_NSD_PRE_XXXX & $\begin{array}{l}\text { TAXABLE VALUE NON-SCHOOL } \\
\text { DISTRICT PRELIMINARY TAX } \\
\text { ROLL YEAR - Reflects the taxable } \\
\text { value for county purposes, is based on } \\
\text { county assessed value, and includes } \\
\text { subtractions for the additional } \$ 25,000 \\
\text { homestead exemption and/or adopted } \\
\text { local exemptions. }\end{array}$ & Ratio & \\
\hline JV_HMSTD_PRE_XXXX & $\begin{array}{l}\text { JUST VALUE HOMESTEAD } \\
\text { PRELIMINARY TAX ROLL YEAR - } \\
\text { Reflects the just value of only that } \\
\text { portion of the parcel that has been } \\
\text { granted a homestead exemption. }\end{array}$ & Ratio & \\
\hline
\end{tabular}




\begin{tabular}{|c|c|c|c|c|}
\hline VARIABLE NAME & VARIABLE DESCRIPTION & $\begin{array}{c}\text { VARIABLE } \\
\text { TYPE }\end{array}$ & ADDITIONAL NOTE(S) & \\
\hline AV_HMST_PRE_XXXX & $\begin{array}{l}\text { ASSESSED VALUE HOMESTEAD } \\
\text { PRELIMINARY TAX ROLL YEAR - } \\
\text { Reflects the assessed value of only that } \\
\text { portion of the property that has been } \\
\text { granted a homestead exemption. }\end{array}$ & Ratio & & \\
\hline JV_NON_HMSTD_RESD_PRE_XXXX & $\begin{array}{l}\text { JUST VALUE NON-HOMESTEAD } \\
\text { RESIDENTIAL PRELIMINARY TAX } \\
\text { ROLL YEAR - Indicates the just value } \\
\text { of only the portion of the property that is } \\
\text { non-homestead residential property } \\
\text { subject to the } 10 \% \text { assessment limitation. }\end{array}$ & Ratio & & \\
\hline AV_NON_HMSTD_RESD_PRE_XXXX & $\begin{array}{l}\text { ASSESSED VALUE NON- } \\
\text { HOMESTEAD RESIDENTIAL } \\
\text { PRELIMINARY TAX ROLL YEAR - } \\
\text { Reflects the assessed value of only the } \\
\text { portion of the property that is non- } \\
\text { homestead residential property subject to } \\
\text { the } 10 \% \text { assessment limitation. }\end{array}$ & Ratio & & \\
\hline JV_FINAL_XXXX & $\begin{array}{l}\text { JUST VALUE FINAL TAX ROLL } \\
\text { YEAR - indicates the opinion of market } \\
\text { value for the final tax roll. }\end{array}$ & Ratio & & \\
\hline JV_CHNG_FINAL_XXXX & $\begin{array}{l}\text { JUST VALUE CHANGE FINAL TAX } \\
\text { ROLL YEAR - Reflects the total change } \\
\text { in just value between the preliminary tax } \\
\text { roll and the final tax roll. }\end{array}$ & Ratio & & \\
\hline \multirow[t]{3}{*}{ JV_CHNG_CD_FINAL_XXXX } & \multirow{3}{*}{$\begin{array}{l}\text { JUST VALUE CHANGE CODE FINAL } \\
\text { TAX YEAR - Reflects the reason code } \\
\text { for change in just value from the } \\
\text { approved preliminary file to the final file. }\end{array}$} & \multirow[t]{3}{*}{ Nominal } & VAB change. & 1 \\
\hline & & & Court required change. & 2 \\
\hline & & & $\begin{array}{l}\text { Revised valuation by a property } \\
\text { appraiser because of receipt or } \\
\text { discovery of additional information }\end{array}$ & 3 \\
\hline
\end{tabular}




\begin{tabular}{|c|c|c|c|c|}
\hline VARIABLE NAME & VARIABLE DESCRIPTION & $\begin{array}{c}\text { VARIABLE } \\
\text { TYPE }\end{array}$ & \multicolumn{2}{|l|}{ ADDITIONAL NOTE(S) } \\
\hline & & & $\begin{array}{l}\text { relating to the physical } \\
\text { characteristics of the property } \\
\text { before the VAB issued a ruling. }\end{array}$ & \\
\hline & & & $\begin{array}{l}\text { Revised valuation by a property } \\
\text { appraiser because of receipt or } \\
\text { discovery of additional information } \\
\text { relating to the physical } \\
\text { characteristics of the property } \\
\text { without a VAB petition having } \\
\text { been filed. }\end{array}$ & 4 \\
\hline & & & $\begin{array}{l}\text { Revised valuation by a property } \\
\text { appraiser because of continued } \\
\text { analysis and/or receipt or discovery } \\
\text { of additional information relating to } \\
\text { the property (other than its physical } \\
\text { characteristics) and after a VAB } \\
\text { petition has been filed but before } \\
\text { the VAB has issued a ruling. }\end{array}$ & 5 \\
\hline & & & $\begin{array}{l}\text { Revised valuation by a property } \\
\text { appraiser because of continued } \\
\text { analysis and/or receipt or discovery } \\
\text { of additional information relating to } \\
\text { the property (other than its physical } \\
\text { characteristics) without a VAB } \\
\text { petition having been filed. }\end{array}$ & 6 \\
\hline AV_SD_POST_XXXX & $\begin{array}{l}\text { ASSESSED VALUE SCHOOL } \\
\text { DISTRICT FINAL TAX ROLL YEAR - } \\
\text { Indicates the assessed value for school } \\
\text { district assessments. The } 10 \% \\
\text { assessment increase limitation on non- } \\
\text { homestead property does not apply to } \\
\text { school district assessed value. }\end{array}$ & Ratio & & \\
\hline
\end{tabular}




\begin{tabular}{|c|c|c|c|}
\hline VARIABLE NAME & VARIABLE DESCRIPTION & $\begin{array}{c}\text { VARIABLE } \\
\text { TYPE }\end{array}$ & ADDITIONAL NOTE(S) \\
\hline AV_NSD_POST_XXXX & $\begin{array}{l}\text { ASSESSED VALUE NON-SCHOOL } \\
\text { DISTRICT FINAL TAX ROLL YEAR - } \\
\text { Indicates the assessed value for non- } \\
\text { school district taxing authorities. } \\
\text { Beginning in 2009, the } 10 \% \text { assessment } \\
\text { increase limitation on non-homestead } \\
\text { property will apply only to non-school } \\
\text { district assessments. }\end{array}$ & Ratio & \\
\hline TV_SD_POST_XXXX & $\begin{array}{l}\text { TAXABLE VALUE SCHOOL } \\
\text { DISTRICT FINAL TAX ROLL YEAR - } \\
\text { Reflects data that represents taxable } \\
\text { value for school purposes, is based on } \\
\text { school-assessed value, and does not } \\
\text { include subtractions for the additional } \\
\$ 25,000 \text { homestead exemption or local } \\
\text { option exemptions. }\end{array}$ & Ratio & \\
\hline TV_NSD_POST_XXXX & $\begin{array}{l}\text { TAXABLE VALUE NON-SCHOOL } \\
\text { DISTRICT FINAL TAX ROLL YEAR - } \\
\text { Reflects data that represents taxable } \\
\text { value for county purposes, is based on } \\
\text { county assessed value, and includes } \\
\text { subtractions for the additional } \$ 25,000 \\
\text { homestead exemption or local option } \\
\text { exemptions. }\end{array}$ & Ratio & \\
\hline JV_HMSTD_POST_XXXX & $\begin{array}{l}\text { JUST VALUE HOMESTEAD FINAL } \\
\text { TAX ROLL YEAR - Reflects data } \\
\text { indicating the just value of only that } \\
\text { portion of the parcel that been granted a } \\
\text { homestead exemption. }\end{array}$ & Ratio & \\
\hline
\end{tabular}




\begin{tabular}{|c|c|c|c|}
\hline VARIABLE NAME & VARIABLE DESCRIPTION & $\begin{array}{c}\text { VARIABLE } \\
\text { TYPE }\end{array}$ & ADDITIONAL NOTE(S) \\
\hline AV_HMST_POST_XXXX & $\begin{array}{l}\text { ASSESSED VALUE HOMESTEAD } \\
\text { FINAL TAX ROLL YEAR - Indicates } \\
\text { the assessed value of only that portion of } \\
\text { the property that has been granted a } \\
\text { homestead exemption. The assessed } \\
\text { value is for school district and non- } \\
\text { school district assessments. }\end{array}$ & Ratio & \\
\hline JV_NON_HMSTD_RESD_POST_XXXX & $\begin{array}{l}\text { JUST VALUE NON-HOMESTEAD } \\
\text { RESIDENTIAL FINAL TAX ROLL } \\
\text { YEAR - Indicates the just value of only } \\
\text { the portion of the property that is non- } \\
\text { homestead residential property subject to } \\
\text { the } 10 \% \text { assessment limitation. }\end{array}$ & Ratio & \\
\hline AV_NON_HMSTD_RESD_POST_XXXX & $\begin{array}{l}\text { ASSESSED VALUE NON- } \\
\text { HOMESTEAD RESIDENTIAL FINAL } \\
\text { TAX ROLL YEAR - Reflects data that } \\
\text { represents assessed value of only the } \\
\text { portion of the property that is non- } \\
\text { homestead residential property subject to } \\
\text { the } 10 \% \text { assessment limitation. }\end{array}$ & Ratio & \\
\hline NO_LND_UNTS & $\begin{array}{l}\text { NUMBER OF LAND UNITS - Indicates } \\
\text { the number of land units used as the basis } \\
\text { of assessment of the land }\end{array}$ & Ratio & \\
\hline LND_SQFOOT & $\begin{array}{l}\text { LAND SQUARE FOOTAGE - Reflects } \\
\text { the equivalent square footage of the site. }\end{array}$ & Ratio & \\
\hline DT_LAST_INSPT & $\begin{array}{l}\text { DATE OF LAST PHYSICAL } \\
\text { INSPECTION - Reflects the month and } \\
\text { year of the last physical on-site } \\
\text { inspection of a parcel. }\end{array}$ & Interval & \\
\hline
\end{tabular}




\begin{tabular}{|c|c|c|c|c|}
\hline VARIABLE NAME & VARIABLE DESCRIPTION & VARIABLE & \multicolumn{2}{|c|}{ ADDITIONAL NOTE(S) } \\
\hline \multirow{6}{*}{ IMP_QUALITY } & \multirow{6}{*}{$\begin{array}{l}\text { IMPROVEMENT QUALITY - Reflects } \\
\text { the general overall quality of the } \\
\text { predominate structure(s) on the property. }\end{array}$} & \multirow[t]{6}{*}{ Ordinal } & Low Cost & 1 \\
\hline & & & Below Average & 2 \\
\hline & & & Average & 3 \\
\hline & & & Above Average & 4 \\
\hline & & & Excellent & 5 \\
\hline & & & Superior & 6 \\
\hline \multirow{5}{*}{ CONST_CLASS } & \multirow{5}{*}{$\begin{array}{l}\text { CONSTRUCTION CLASS - Represents } \\
\text { a code denoting the general overall } \\
\text { construction class of the predominate } \\
\text { structure(s) on the property. }\end{array}$} & \multirow{5}{*}{ Nominal } & Fireproof Steel & 1 \\
\hline & & & $\begin{array}{l}\text { Reinforced } \\
\text { Concrete }\end{array}$ & 2 \\
\hline & & & Masonry & 3 \\
\hline & & & Wood & 4 \\
\hline & & & Steel Frame & 5 \\
\hline EFF_YR_BLT & $\begin{array}{l}\text { EFFECTIVE YEAR BUILT - } \\
\text { Represents the effective year built of the } \\
\text { primary structure. Often used as the } \\
\text { basis of calculating the depreciation of a } \\
\text { structure. }\end{array}$ & Interval & & \\
\hline ACT_YR_BLT & $\begin{array}{l}\text { ACTUAL YEAR BUILT - Indicates the } \\
\text { actual year built of the primary structure } \\
\text { on the parcel. }\end{array}$ & Interval & & \\
\hline TOT_LVG_AREA & $\begin{array}{l}\text { TOTAL LIVING AREA - Reflects the } \\
\text { total effective (or adjusted) area of all } \\
\text { improvements on the property. }\end{array}$ & Ratio & & \\
\hline QUAL_CD1 & $\begin{array}{l}\text { QUALIFICATION CODE SALE } 1- \\
\text { Denotes sales qualification decisions } \\
\text { made by the property appraiser. The } \\
\text { codes are established by the FDOR and } \\
\text { are used to reflect certain characteristics } \\
\text { of the transfer. }\end{array}$ & Nominal & See: Sales Quali & on Codes \\
\hline
\end{tabular}




\begin{tabular}{|c|c|c|c|c|}
\hline VARIABLE NAME & VARIABLE DESCRIPTION & $\begin{array}{c}\text { VARIABLE } \\
\text { TYPE }\end{array}$ & \multicolumn{2}{|c|}{ ADDITIONAL NOTE(S) } \\
\hline \multirow[t]{2}{*}{ VI_CD1 } & \multirow{2}{*}{$\begin{array}{l}\text { VACANT / IMPROVED CODE SALE } 1 \\
\text { - Indicates whether the parcel was vacant } \\
\text { land or improved property at the time of } \\
\text { sale. }\end{array}$} & \multirow[t]{2}{*}{ Nominal } & Vacant & $\mathrm{V}$ \\
\hline & & & Improved & $\mathrm{I}$ \\
\hline SALE_PRC1 & $\begin{array}{l}\text { SALE PRICE SALE } 1-\text { Represents the } \\
\text { sales price of the transaction as indicated } \\
\text { by the documentary stamps on the deed. }\end{array}$ & Ratio & & \\
\hline SALE_YR1 & $\begin{array}{l}\text { SALE YEAR SALE } 1 \text { - Represents the } \\
\text { sale year of the transactions listed. }\end{array}$ & Interval & & \\
\hline SALE_MO1 & $\begin{array}{l}\text { SALE MONTH SALE } 1 \text { - Represents } \\
\text { the sale month of the transaction listed }\end{array}$ & Interval & & \\
\hline QUAL_CD2 & $\begin{array}{l}\text { QUALIFICATION CODE SALE } 2- \\
\text { Denotes sales qualification decisions } \\
\text { made by the property appraiser. The } \\
\text { codes are established by the FDOR and } \\
\text { are used to reflect certain characteristics } \\
\text { of the transfer. }\end{array}$ & Nominal & See: Sales & ation Codes \\
\hline \multirow[t]{2}{*}{ VI_CD2 } & \multirow{2}{*}{$\begin{array}{l}\text { VACANT / IMPROVED CODE SALE } 2 \\
\text { - Indicates whether the parcel was vacant } \\
\text { land or improved property at the time of } \\
\text { sale. }\end{array}$} & \multirow[t]{2}{*}{ Nominal } & Vacant & $\mathrm{V}$ \\
\hline & & & Improved & I \\
\hline SALE_PRC2 & $\begin{array}{l}\text { SALE PRICE SALE } 2 \text { - Represents the } \\
\text { sales price of the transaction as indicated } \\
\text { by the documentary stamps on the deed. }\end{array}$ & Ratio & & \\
\hline SALE_YR2 & $\begin{array}{l}\text { SALE YEAR SALE } 2 \text { - Represents the } \\
\text { sale year of the transactions listed. }\end{array}$ & Interval & & \\
\hline SALE_MO2 & $\begin{array}{l}\text { SALE MONTH SALE } 2 \text { - Represents } \\
\text { the sale month of the transaction listed. }\end{array}$ & Interval & & \\
\hline OWN_NAME & $\begin{array}{l}\text { OWNER'S NAME - Indicates the } \\
\text { primary owner’s name. }\end{array}$ & Nominal & & \\
\hline CENSUS_BK & $\begin{array}{l}\text { CENSUS BLOCK GROUP NUMBER - } \\
\text { Identifies the US Census Block Group of } \\
\text { the parcel or center of the parcel if } \\
\text { located within multiple block groups. }\end{array}$ & Nominal & & \\
\hline
\end{tabular}




\begin{tabular}{|c|c|c|c|}
\hline VARIABLE NAME & VARIABLE DESCRIPTION & $\begin{array}{c}\text { VARIABLE } \\
\text { TYPE }\end{array}$ & ADDITIONAL NOTE(S) \\
\hline PHY_ZIPCD & $\begin{array}{l}\text { PHYSICAL LOCATION ZIP CODE - } \\
\text { Represents the zip code for the parcel as } \\
\text { designated by the United States Postal } \\
\text { Service. }\end{array}$ & Nominal & \\
\hline EXEMPTIONS & $\begin{array}{l}\text { EXEMPTIONS - Indicate the value of } \\
\text { the specific exemption for the parcel as } \\
\text { determined by the property appraiser. }\end{array}$ & Nominal & \\
\hline MP_ID & $\begin{array}{l}\text { MASTER PARCEL IDENTIFICATION } \\
\text { CODE - Reflects a unique code } \\
\text { generated by the FDOR for use its } \\
\text { database management. }\end{array}$ & Nominal & \\
\hline TRACTNUMBER & $\begin{array}{l}\text { TRACT NUMBER - Identifies the US } \\
\text { Census tract in which the parcel is } \\
\text { located. }\end{array}$ & Ratio & \\
\hline TRACT_EST_TOTAL & $\begin{array}{l}\text { TRACT ESTIMATED TOTAL } \\
\text { PERCENTAGE - Indicates the total } \\
\text { estimated population for the tract, }\end{array}$ & Ratio & \\
\hline PERCENT OF TRACT WHITE & $\begin{array}{l}\text { TRACT PERCENTAGE WHITE - } \\
\text { Indicates the percentage of tract } \\
\text { population, which identifies as white. }\end{array}$ & Ratio & \\
\hline PERCENT OF TRACT BLACK & $\begin{array}{l}\text { TRACT PERCENTAGE BLACK - } \\
\text { Indicates the percentage of tract } \\
\text { population, which identifies as black. }\end{array}$ & Ratio & \\
\hline TRACT_PERC_AIAN & $\begin{array}{l}\text { TRACT PERCENTAGE NATIVE } \\
\text { AMERICAN - Indicates the percentage } \\
\text { of tract population, which identifies as } \\
\text { native American. }\end{array}$ & Ratio & \\
\hline TRACT_PERC_ASIAN & $\begin{array}{l}\text { TRACT PERCENTAGE ASIAN - } \\
\text { Indicates the percentage of tract } \\
\text { population, which identifies as Asian. }\end{array}$ & Ratio & \\
\hline
\end{tabular}




\begin{tabular}{|c|c|c|c|}
\hline VARIABLE NAME & VARIABLE DESCRIPTION & $\begin{array}{c}\text { VARIABLE } \\
\text { TYPE }\end{array}$ & ADDITIONAL NOTE(S) \\
\hline TRACT_PERC_HAWPAC & $\begin{array}{l}\text { TRACT PERCENTAGE HAWAIIAN } \\
\text { PACIFIC AMERICAN Ratio - Indicates } \\
\text { the percentage of tract population, which } \\
\text { identifies as Hawaiian or Pacific } \\
\text { American. }\end{array}$ & Ratio & \\
\hline TRACT_PERC_OTHER & $\begin{array}{l}\text { TRACT PERCENTAGE OTHER - } \\
\text { Indicates the percentage of tract } \\
\text { population, which identifies as other. }\end{array}$ & Ratio & \\
\hline TRACT_PERC_HS & $\begin{array}{l}\text { TRACT PERCENTAGE HIGH } \\
\text { SCHOOL - Indicates the percentage of } \\
\text { tract population with a high school } \\
\text { degree. }\end{array}$ & Ratio & \\
\hline PERCENT W/AT LEAST BACHELOR & $\begin{array}{l}\text { TRACT PERCENTAGE BACHELOR } \\
\text { DEGREE OR BETTER - Indicates the } \\
\text { percentage of tract population at least a } \\
\text { bachelor's degree. }\end{array}$ & Ratio & \\
\hline TRACT_HH_MED_INC & $\begin{array}{l}\text { TRACT MEDIAN HOUSEHOLD } \\
\text { INCOME - Indicates median household } \\
\text { income for a given tract. }\end{array}$ & Ratio & \\
\hline TRACT_HM_MEDVAL & $\begin{array}{l}\text { TRACT MEDIAN HOME VALUE - } \\
\text { Indicates median home value for a given } \\
\text { tract. }\end{array}$ & Ratio & \\
\hline SALES PER TRACT & $\begin{array}{l}\text { SALES PER TRACT - Indicates the } \\
\text { number of qualified sales in a given tract } \\
\text { for a given year. }\end{array}$ & Ratio & \\
\hline JV_PREV_YEAR & $\begin{array}{l}\text { JUST VALUE PREVIOUS YEAR - } \\
\text { Indicates the just value from the previous } \\
\text { tax year. }\end{array}$ & Ratio & \\
\hline
\end{tabular}




\section{VITA}

\section{MICHAEL P. PAPARESTA}

1997-1999

2002-2003

2007-2015

2001-2015

2005-2015

2013
B.S., Real Estate

Florida State University

Tallahassee, Florida

Master of Public Administration

Florida International University

Miami, Florida

Doctoral Candidate

Florida International University

Miami, Florida

Miami-Dade County

Office of the Property Appraiser

Income Specialist

Real Estate Evaluator 2

Real Estate Evaluator 1

Certified Florida Evaluator

C. Lowell Harriss Dissertation Fellowship

Lincoln Institute of Land Policy 